

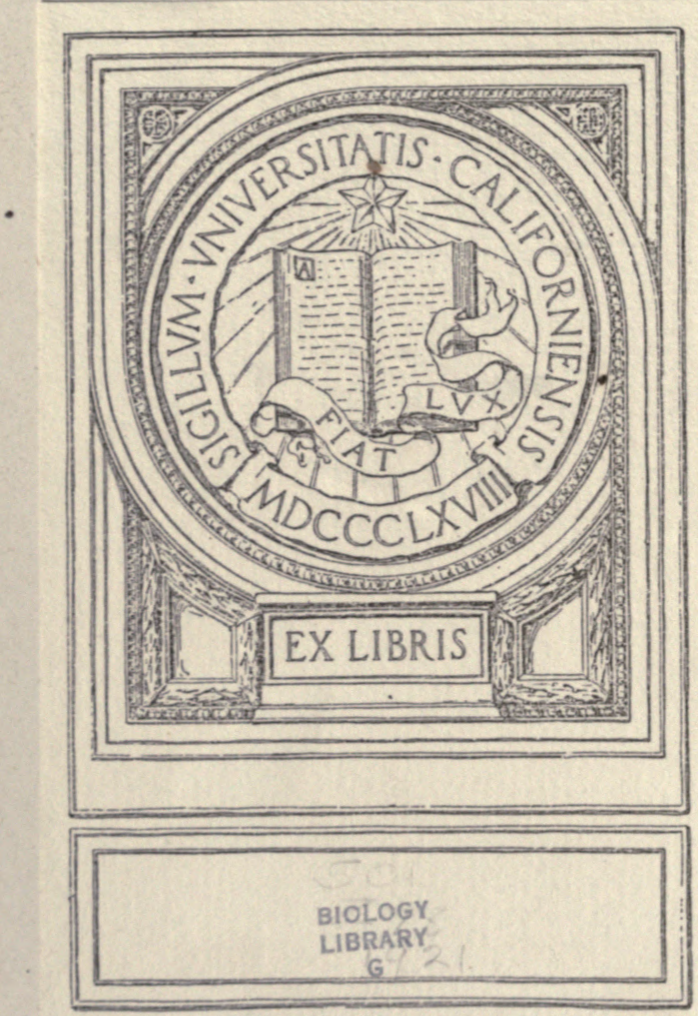






A LABORATORY COURSE IN SERUM STUDY 


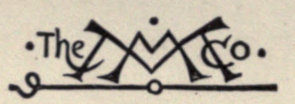

THE MACMILLAN COMPANY

NEW YORK - BOSTON - CHICAGO - DALLAS

ATLANTA - SAN FRANCISCO

MACMILLAN \& CO., LIMITED
LONDON - BOMBAY . CALCUTTA MELBOURNE

THE MACMillan CO. OF CANADA, Ltd.

TORONTO 


\section{A LABORATORY COURSE IN SERUM STUDY}

BACTERIOLOGY 208

BEING A SERIES OF EXPERIMENTS AND DIAGNOSTIC TESTS IN IMMUNOLOGY CARRIED OUT IN AN OPTIONAL COURSE GIVEN TO MEDICAL AND GRADUATE STUDENTS IN THE DEPARTMENT OF BACTERIOLOGY, COLLEGE OF PHYSICIANS AND SURGEONS COLUMBIA UNIVERSITY

NEW YORK, BY THE WRITERS

HANS ZINSSER, M.D.

J. G. HOPKINS, M.D.

REUBEN OTTENBERG, M.D.

SECOND EDITION REVISED

Nơw 19ork

THE MACMILLAN COMPANY

1921

All rights reserved 
$\because \because \because \quad \quad 309090900$

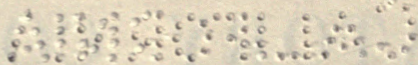

QTR 183

Z5

1921

BIOLOGK
LIBRARK

G

Copyright, 1916, 1921,

BY THE MACMILLAN COMPANY.

Set up and electrotyped. Published February, 1916.

New Edition Revised. Published January, 1921.

replacing 830085 


\section{PREFACE TO SECOND EDITION}

THE present issue of the Laboratory Course in Serum Study does not represent a new edition in that it has been found impossible to completely revise the book at this time. There are, however, a number of important changes in protocols and technique which have been made on the basis of experience in giving the course to medical and public health students. Most of these changes are in the form of alterations in the plan of experiments, making them more easy to perform and more illustrative of underlying principles. In preparing these changes for the new printing, we have been greatly aided by Dr. Samuel Cochran, Professor of Bacteriology at the Shantung Christian University in China, who helped us in giving this course at Columbia last year. 



\section{INTRODUCTION}

The course here outlined is given by the authors at Columbia University. The prerequisite theoretical knowledge is presented in a series of lectures based on the textbook "Infection and Resistance," by the senior author.

Immunity, like other branches of science, cannot be taught without experiment and demonstration. For this reason we have, for several years, supplemented our lecture course on Infection and Resistance by an optional course on Serum Technique. Our purpose in this has been not so much to teach beginners to carry out practical diagnostic tests as to allow the student to carry out fundamental experiments, and, in drawing conclusions from his results, to learn to reason from protocols and in this way discover the basic principles for himself.

It has been our contention for a number of years that thorough instruction in the phenomena of immunity constituted a logically necessary preparation for the clinic on infectious diseases. For this reason our courses have been offered as optionals to second and third year medical students. Contrary to ordinary belief, students at this stage of preparation have found no difficulty in comprehending the work, and have, we think, derived benefits in experimental methods and reasoning far beyond the actual gain in new facts. Though optional now, these courses we hope may eventually become integral, required parts of the regular medical curriculum - the lectures and demonstrations correlated with - the laboratory course following - the course in Bacteriology. This, however, we realize may have to await the lengthening of the medical course as a whole. Meanwhile such a course can certainly be optionally 
available for students who have the desire to take it - and our experience at two medical schools has taught us that there are always a good many who do.

The little volume has been compiled in the first place for our own convenience from the protocols given to our students. If incidentally it is of service to others in planning similar courses, or to laboratory workers in repeating experiments, we shall be pleased. The book as it stands is, of course, not a manual of immunity. The course should follow or be synchronous with lectures, reading, and demonstrations on the principles of infection and immunity. In our own work the course is offered to students who have had work in general Bacteriology and have taken the lecture course on Infection and Resistance, and reading is assigned in the textbook on this subject.

Since the manual has grown out of the course after some four years of experimentation and adaptation to classroom possibilities, it in no way represents an "ideal" formula but describes only work actually done with students. For this reason we have often simplified the experiments in a way which would be undesirable in actual research work. But we have not done this at the expense of exactitude. Thus we have in many cases adapted the technique to the possibilities of a single afternoon with a class not yet fully trained. In order to facilitate the giving of such a course by other teachers we have added a time schedule of the whole conrse, and have given in each exercise a list of the materials needed. 


\section{TIME SCHEDULE OF LESSONS ${ }^{1}$}

Subject of Lesson

I. Immunization of Amimals.

II. Bactericidal and Hamolytic Power of Normal SERUM.

III. H五MOLYSIS.

IV. Quantitative Relations OF AMBOcEPTOR AND CoMplement.

V. Quantitative Relations (Continued).

VI. Reversibility aNd Speed OF UNION OF IMMUNE Body and Cells.

VII. Pfeiffer Phenomenon.
Work Preliminary to SubseQUent Lessons

Preparation of B. typhosus.

B. coli.

Staphylococcus aureus.

Vibrio choleræ.

Sheep serum.

Ascitic serum.

Sheep red cells.

Cat red cells.

Horse serum.

Human serum.

Injection of rabbits.

Repetition of injections of Lesson I.

Repeat injections of Lesson I.

Commence collection of guinea pig hearts in absolute alcohol for Wassermann antigen (Lesson XIX).

Repeat injections of Lesson I.

Repeat certain injections of Lesson I.

Trial bleeding of animals which received their last injections at 4 th session.

Bleeding of animals of Lesson I.

${ }_{1}^{1}$ Arranged for two afternoons a week for a term of three and a half months. 
SubJect of Lesson

VIII. Bactericidal Tests in VItro.

IX. Agglutinins.

X. Agglutination-MicroSCOPIC METhod. EFFECT OF SALT.

XI. Absorption of AgglutiNINS.

XII. In Vivo EFfect ôf HæMAGGLUTINATIVE AND Hamolytic Sera.

XIII. IsOHAMOLYSIS AND IsoAgGLUTINATION.

XIV. Precipitins.

XV. Forensic Precipitin Test.

XVI. Bordet-Gengou PhenomENON.

XVII. Alexin Fixation by Specific Precipitates.

XVIII. Forensic Complement Fixation.

XIX. Wassermann Antigen: Preparation and Titration of Antigen.

XX. Wassermann Reaction: Technique of Tests.

XXI. Complement Fixation with Bacterial ExTRACTS.
Work Preliminary to SubseQUENT Lessons

Titrate hemolytic sera made by class.

Inoculate flasks with virulent diphtheria strain for production of diphtheria toxin (Lesson XXII).

Filter diphtheria toxin (Lesson XXII).

Begin preparation of Wassermann antigens for Lesson XIX.

Inject guinea pigs with diphtheria toxin for determination of minimal lethal dose (Lesson XXII).

Finish preparation of simple alcoholic Wassermann antigen and Noguchi antigen.

Inject guinea pigs with diphtheria toxin-antitoxin mixtures for determination of $\mathrm{L}$ dose (Lesson XXII). 
Subject of Lesson

XXII. Diphtheria Toxin: TITRATION OF AN UNknown Antitoxin.

XXIII. Tetanus Toxin; TetANolysin and ANtitetanolysin ; TeTANOSPASMIN.

XXIV. Cobra Venom, Ricix, SAPONIN.

XXV. Antitrypsin.

XXVI. Normal Opsonins.

XXVII. OPSONIC INDEX: Wright's Technique.

XXVIII. Heat Stability of Opsonins.

XXIX. Titration of Normal Opsonins by Dilution Method.

XXX. Titration of Immune Opsonins by Dilution Method.

XXXI. Preparation of Bacterial Vaccines.

XXXII. Avaphylaxis.
Work Preliminary to Subsequent Lessons

Inject guinea pigs with serum for Lesson XXXII. 



\section{TO BE PREPARED OR OBTAINED BY INSTRUCTOR}

Before Course.

Before Lesson I.

Before Lesson II.

Before Lessons III, IV, V, AND VI.

Before Lesson VII.

Before Lesson VIII.

Before Lesson IX.

Before Lesson X.

Before Lesson XI.

Before Lesson XII.
Hæmolytic (antisheep) serum.

Immunize a guinea pig to cholera spirillum.

Inoculate students against typhoid.

One day before lesson plant agar slants of B. typhosus, B. coli, Staphylococcus aureus, Vibrio choleræ.

Obtain sheep serum, ascitic fluid, horse serum, sheep's blood, two cats, ten rabbits, one guinea pig.

One day before, inoculate broth culture of B. typhosus.

Fresh dog serum.

Washed guinea pig cells.

Washed human cells.

Sheep's blood (washed).

Fresh guinea pig serum.

Diluted hæmolytic serum.

Plant culture of virulent cholera vibrios.

Guinea pig immunized to cholera.

24 hours before, plant broth culture of B. typhosus.

Obtain sterile blood from normal rabbit.

24 hour broth culture typhoid.

Virulent diphtheria strain.

24 hour broth culture B. typhosus.

Slant cultures of B. typhosus and B. coli.

Two cats, one rabbit. 
Before Lesson XIII.

Before Lesson XV.

Before Lesson XVI.

Before Lesson XVIII.

Before Lesson XIX.

BeFore Lesson XXIII.

Before Lesson XXIV.

Before Lesson XXV.

Before Lesson XXVI.

Before Lesson XXVII.

Before Lesson XXVIII.

Before Lesson XXIX.
Beef hearts.

Absolute alcohol for Wassermann antigens.

Prepare blood stains to be tested.

Typhoid slants.

Obtain standard diphtheria antitoxin.

Horse meat. Give to class at previous exercise.

Syphilitic and normal human sera.

Tetanus toxin and antitoxin. Test hæmolytic power of toxin.

Guinea pig brains.

Guinea pigs.

Cobra venom. Saponin, ricin, lecithin.

Guinea pig's blood. Sheep blood.

Prepare alkaline casein solution and trypsin solution.

Obtain blood from carcinoma and other patients.

Inject guinea pigs with aleuronat.

Slants of Staphylococcus aureus.

Guinea pig serum.

Inoculate slants with Staphylococcus aureus.

Glass tubing for making Wright's capsules and pipettes.

Rubber nipples.

Triangular files.

Citrate solution.

Staphylococcus immune guinea pig serum.

Staphylococcus emulsions.

Guinea pigs for preliminary work for Lesson XXXII.

Horse serum.

Sheep serum.

Guinea pig serum.

Same materials as for Lessons XXVII and XXVIII. 
TO BE PREPARED OR OBTAINED BY INSTRUCTOR Xiii

Before Lesson XXX.

Brfore Lesson XXXI.

Before Lesson XXXII.

Before Lesson XXXIII.
Serum of rabbit immunized against staphylococcus.

Inject guinea pig with aleuronat. * Serum of normal rabbit.

Other materials same as for three preceding lessons.

Agar slants of Staphylococcus aureus.

Sterile tubes with glass beads.

Hæmocytometers.

Methylene blue solution.

Wright's stain or Jenner's stain.

Hopkins centrifuge tube.

Horse serum.

Sheep serum.

Immune anti-horse serum injected into guinea pigs day before lesson.

Horse serum. 


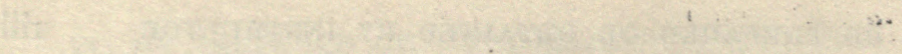


A LABORATORY COURSE IN SERUM STUDY 


\section{LESSON I}

Students in this course will prepare their own materials for injection, will immunize and bleed animals themselves, in fact will do all the manipulations necessary in the preparation of materials for the experiments that are done in the class. In some cases students will work in groups of two or more in order to save time and animals.

It is suggested that each student be required to enter his results on a joint tabulation sheet prepared for each day's exerciseand that theseresults be discussed by the instructor at the beginning of the following exercise.

\section{PREPARATION OF MATERIALS FOR INJECTION}

\section{Sheep ERYthrocytes}

The students who are to immunize their rabbit to blood cells should obtain the blood from the sheep, and at subsequent lessons other students will be given experience in this procedure.

Bleeding of Sheep. - The animal is held by two assistants with the head thrown back and one side of the neck is clipped and carefully shaved.

A rubber tourniquet is then placed around the neck as near as possible to the shoulders and tied tightly so as to compress the external jugular vein. The vein distends and will be seen to stand out as a ridge the size of a finger. A small part of the shaved area of the skin is painted with tincture of iodine, and a large sterile needle with four inches of rubber tubing attached is plunged through the skin into the vein. The blood is allowed to flow into small Erlenmeyer flasks containing about 20 large beads, and when the desired amount of blood is obtained the flask is shaken thoroughly until coagulation is completed, this procedure defibrinating the blood. If preferred, the blood may be received into citrate solution, containing 1 per cent sodium citrate and 0.5 per cent sodium chloride (not more than 1 part of blood to 1 part of solution) or into ammonium oxalate solution ( 1 per cent).

To obtain washed erythrocytes and serum for injection the defibrinated blood is poured into sterile centrifuge tubes. The cotton plugs of these tubes should be fastened by turning the free edges back over the neck of the tube and securing them there by means of rubber bands; this will prevent the 

plug being thrown to the bottom of the tube during centrifugation. The cotton plug may also be replaced by a cap of sterile tin foil. After careful balancing, the tubes are centrifugalized at high speed until the sediment is thrown down. The supernatant fluid is removed with a sterile pipette and in this case should be preserved for the injection of rabbits for the production of precipitins. The tubes are then filled with sterile salt solution, the blood cells resuspended by drawing them in and out of a pipette and again thrown down in the centrifuge. This process is repeated three times. The washed sediment is then transferred to another tube with a graduated pipette and an equal amount of salt solution added to make the $50 \%$ suspension which is used for injection.

\section{Preparation of Bacterial Emulsions}

Ten c.c. of sterile salt solution are added by means of a pipette to a 24-hour culture on slant agar of the particular organism to be used. Surface growth is scraped from the agar by means of a platinum loop and the bacteria suspended in salt solution by gentle shaking. The suspension is then poured off into a sterile test tube, carefully flaming the mouths both of the culture tube and the sterile test tube before pouring. The second tube may then be drawn out and sealed in a blowpipe flame, and the tube entirely immersed in a water bath for sterilization; or the upper portion of the tube may be carefully heated in a Bunsen flame to kill any bacteria which may be adherent to the side of the upper portion, and when the tube has cooled the lower portion is then immersed in a water bath, taking care that the level of the water comes well above the portion which has not been sterilized by flaming. The bacteria should be heated at $60^{\circ} \mathrm{C}$. for one half hour and are then ready for injection.

\section{Preparation of Serum for Injection}

The serum or ascitic fluid used for the production of precipitins should be clear and sterile and is less toxic if heated for 30 minutes at $56^{\circ} \mathrm{C}$. before injection. It requires no other preparation. 



\section{CARE OF ANIMALS}

The animals used for the routine work of the course are mainly guinea pigs and rabbits; in some cases dogs or cats are used, and for demonstration a sheep is used on one or two occasions. Animals used should be selected from among the healthy stock; animals having suppurations, diseased eyes, or skin diseases should be discarded. They should be well nourished and before immunization is begun should be weighed and the weight recorded. During the course of treatment students should, if possible, supervise the feeding and caging of their animals. Care should be taken that the cages are kept reasonably dry, that the animals have plenty of water to drink and the food is abundant, and that not too much green feed is given. If any of the rabbits under treatment show a catarrhal discharge from the nostrils, a condition spoken of by animal dealers as "wet mouth", these animals should be segregated and their nostrils and forepaws washed daily with weak bichloride solution. Great care should be taken that the food soiled by these animals is not put into cages of the healthy ones. Rabbits and guinea pigs are best preserved in a warm place, and wood bottoms on the floors of bins and cages are much better than either cement or tin unless these are covered. They should not be allowed to live for days on floors wet and soiled with their own discharges. During the immunization the animals should be weighed periodically and their weight recorded, and if great emaciation and loss of weight ensues in an individual case, the animal should be given a rest and carefully fed. Unless this is done many of the animals will die in the course of immunization.

There is certain to be a considerable mortality among the animals even if the greatest care is used, and it is wise to start immunizing two individuals for each sort of substance used as antigen.

\section{METHODS OF INJECTION}

\section{InTRAVENOUS INJECTION}

When a rabbit is to be injected the animal is held by an assistant. The outer border of the hairy side of the ear is shaved and 

rubbed vigorously with alcohol until the marginal vein distends. The needle of the syringe is then introduced into the vein, pointing toward the base of the ear, and the material injected, care being taken to avoid the introduction of bubbles. When the needle is withdrawn a small piece of absorbent cotton is pressed over the puncture to stop bleeding. It is well to leave this cotton adherent to the puncture when the animal is returned to the cage.

In injecting guinea pigs intravenously it is necessary to incise the skin of the neck and expose the external jugular vein, and unless a very small needle is used the vein must be tied off after injection has been made. Etherization is needed for this procedure.

The injection of mice and rats intravenously is difficult, but can be accomplished by rubbing the tail with xylol and holding. the mouse so that the tail bends sharply over the edge of the jar. The four parallel veins will then stand out and with eare a very fine needle can be introduced into one of them.

\section{INTRAPERITONEAL INJECTIONS}

A rabbit or guinea pig is held back down by an assistant and a small area of the abdominal wall median line clipped and the skin disinfected with alcohol or iodine. A fold of skin and muscle is pinched up with the left hand, and the needle, which should not be too sharp, is cautiously introduced directly into the peritoneal cavity and the injection made. The safest point is the median line below the umbilicus, as in this area there is little danger of puncturing the stomach or large intestine.

\section{Subcutaneous Injections}

Subcutaneous injections are made in a similar way, after clipping the hair of the area selected and pinching up a fold of skin, taking care that the needle does not pass into the muscles. Rabbits and guinea pigs are usually injected into the surface of the abdomen, rats and-mice at the root of the tail. If there is danger of the substance injected causing ulceration, as in the case of red cells, it is best to inject rabbits under the skin of the back, as this area is less likely to become infected. 


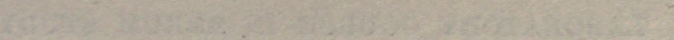

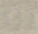

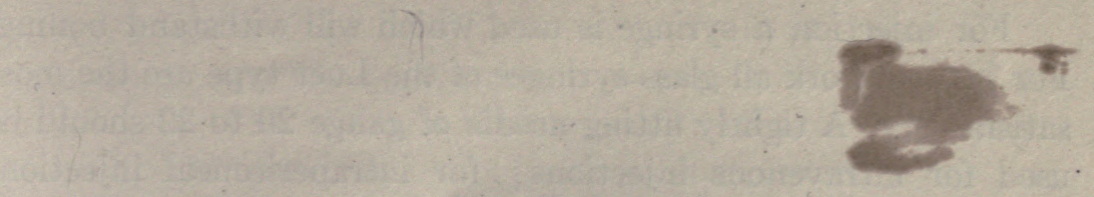

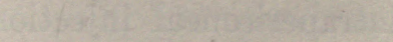

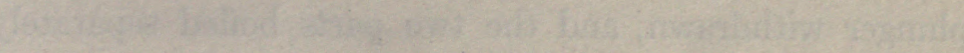

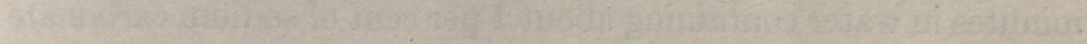

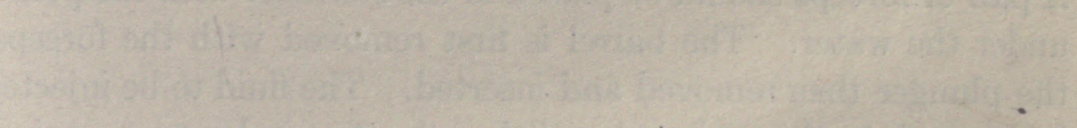

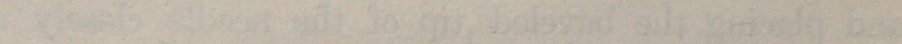

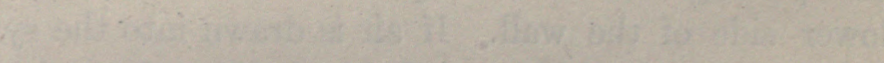

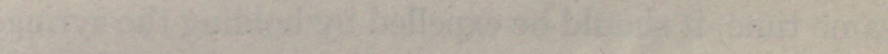

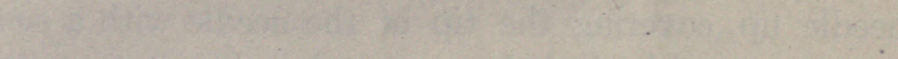
c.

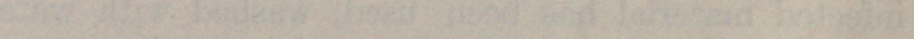

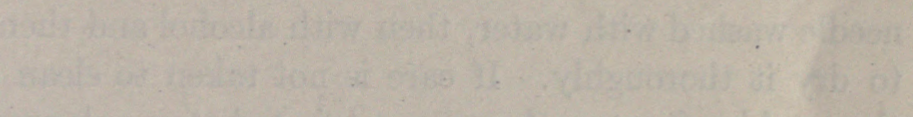

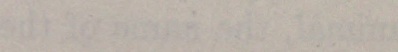


For injection a syringe is used which will withstand boiling. For general work all glass syringes of the Luer type are the most satisfactory. A tightly fitting needle of gauge 20 to 22 should be used for intravenous injections; for intraperitoneal injections larger needles may be used if desired. If glass syringes are used the needle may be attached to the barrel of the syringe, the plunger withdrawn, and the two parts boiled separately for 5 minutes in water containing about 1 per cent of sodium carbonate. A pair of forceps should be placed in the sterilizer with the points under the water. The barrel is first removed with the forceps, the plunger then removed and inserted. The fluid to be injected is drawn into the syringe by tilting the test tube or container and placing the beveled tip of the needle closely against the lower side of the wall. If air is drawn into the syringe at the same time, it should be expelled by holding the syringe vertically, needle up, covering the tip of the needle with a small piece of cotton wet with alcohol or some other disinfectant and expelling the air. After use the syringe should be resterilized if any infected material has been used, washed with water, and the needle washed with water, then with alcohol and then with ether to dry it thoroughly. If care is not taken to clean the needles thoroughly after use, they are certain to become clogged. If blood or serum have been injected, the needle and syringe must be cleaned with cold water at once. Otherwise if alcohol or boiling water is used, the protein will be coagulated and the needle clogged.

Animals should be labeled by attaching a number tag by means of a metal staple to the ear, should be placed in a cage with a tag recording the number of the animal, the name of the student in charge and the nature of the material injected, and the date of each injection.

Scheme for Injections (Approximate Doses and Intervals)

1. Rabbit immunized to B. typhosus by intravenous injection.

1st day 1st dose 0.05 agar slant

6 th day $2 \mathrm{~d}$ dose 0.1 agar slant

11 th day $3 \mathrm{~d}$ dose 0.2 agar slant

16th day 4th dose 0.2 agar slant

heated as

24th day 5 th dose 0.2 agar slant

indicated

below 

2. Rabbit immunized to B. typhosus by subcutaneous injections. Injections at five or six day intervals, followed by intravenous injections.

1st dose 0.1 agar slant
$2 \mathrm{~d}$ dose 0.2 agar slant
$3 \mathrm{~d}$ dose 0.3 agar slant
4th dose 0.5 agar slant
5th dose 0.5 agar slant

3. Rabbit immunized to B. typhosus and to B. coli communior by intravenous injection. Intervals as above.
1st dose 0.05 agar slant of B. typhosus
$2 \mathrm{~d}$ dose 0.1 agar slant of $\mathrm{B}$. typhosus
$3 \mathrm{~d}$ dose 0.2 agar slant of $\mathrm{B}$. typhosus
4th dose 0.2 agar slant of $B$. typhosus, plus
0.05 agar slant of $\mathrm{B}$. coli communior
5th dose 0.2 agar slant of B. typhosus, plus
0.05 agar slant of $\mathrm{B}$. coli communior
6th dose 0.2 agar slant of B. typhosus, plus
0.1 agar slant of $\mathrm{B}$. coli communior

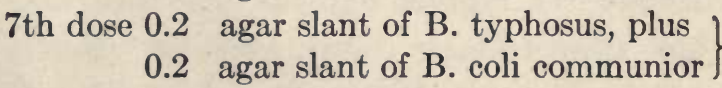

4. Guinea pig immunized to Sp. choleræ by intraperitoneal injection. An old laboratory strain of the cholera vibrio should be used for immunization. Intervals as above.

\begin{tabular}{|c|c|}
\hline 1st dose 0.05 & $r_{\mathrm{s}}$ \\
\hline $2 \mathrm{~d}$ dose 0.1 & agar slant \\
\hline $3 \mathrm{~d}$ dose 0.2 & agar slant \\
\hline dose 0.2 & agar slant \\
\hline th dose 0.2 & agar slant \\
\hline
\end{tabular}

5. Rabbit immunized to micrococcus aureus by intravenous injection. Intervals as above. In the case of this microörganism the intervals should be lengthened if there is any indication of illness. Great care is necessary in avoiding overdosage.

1st dose 0.05 agar slant

$2 \mathrm{~d}$ dose 0.1 agar slant

$3 \mathrm{~d}$ dose 0.2 agar slant

4 th dose 0.2 agar slant

5th dose 0.2 agar slant 

6. Rabbit immunized to sheep serum by intravenous injection. Five-day intervals.

1st dose 2.0 c.c.

$2 \mathrm{~d}$ dose 2.0 c.c.

$3 \mathrm{~d}$ dose 2.0 c.c.

7. Rabbit immunized to human serum (ascitic fluid) by intravenous injection. Five-day intervals.

$$
\begin{aligned}
& \text { 1st dose } 4.0 \text { c.c. } \\
& \text { 2d dose } 4.0 \text { c.c. } \\
& 3 \text { d dose } 4.0 \text { c.c. }
\end{aligned}
$$

8. Rabbit immunized to horse serum. (Immunize not_less than three in order to obtain sufficient serum for later exercises.)

$$
\begin{aligned}
& \text { 1st dose } 2.0 \text { c.c. } \\
& 2 \mathrm{~d} \text { dose } 2.0 \text { c.c. } \\
& 3 \mathrm{~d} \text { dose } 2.0 \text { c.c. }
\end{aligned}
$$

9. Rabbit immunized to sheep erythrocytes by intravenous injection. Four or five day intervals.

1st dose 4.0 c.c. of $50 \%$ suspension

$2 \mathrm{~d}$ dose 4.0 c.c. of $50 \%$ suspension

$3 \mathrm{~d}$ dose 4.0 c.c. of $50 \%$ suspension

A fourth injection may be given in some cases, but is not often necessary.

10. Rabbit immunized to sheep erythrocytes by intraperitoneal injections. Intervals as above.

1st dose 4.0 c.c. of $50 \%$ suspension

$2 \mathrm{~d}$ dose 8.0 c.c. of $50 \%$ suspension

$3 \mathrm{~d}$ dose 8.0 c.c. of $50 \%$ suspension

4th dose 8.0 c.c. of $50 \%$ suspension

11. Rabbit immunized to cat erythrocytes by intravenous injections of 2 c.c. at 4-day intervals. - See Lesson XII.

A preliminary titration of the serum done with a specimen obtained from an ear vein should be done about the eighth or ninth day after the last injection. If this is satisfactory, the bleeding of the animal is usually done the ninth or tenth day. No absolute rule can be established as to exact period at which the serum has the highest antibody concentration, this depending to 

some extent on the health of the animal, the size of the injections, and the intervals. It is a safe rule to assume that the high point in the curve is apt to lie between the eighth and the twelfth day after the last injection and to be guided by this in preliminary titrations.

\section{THE BLEEDING OF ANIMALS}

Before the immunization of the animal is begun a sample of blood should be taken from the ear vein of the animal and the serum stored in the refrigerator for use as a control at a later exercise when the serum of this animal is tested for immune bodies. The blood can be obtained from the marginal vein in the ear in the following manner.

The animal is firmly held with the head down by an assistant. The lateral portion of the hairy surface of the ear is carefully shaved and the skin rubbed vigorously to cause the veins to distend. If necessary the ear may be rubbed with xylol. The skin over the vein is washed over with alcohol and a cut made in the vein with a razor blade or other sharp instrument. The blood is allowed to drip into a clean centrifuge tube until about 4 c.c. (60 drops) are obtained. It is then allowed to coagulate and the edges of the clot are freed from the side of the tube by means of a sterile platinum wire. The tube is centrifugalized and the clear serum thus expressed is transferred to a sterile test tube by means of a capillary pipette with a rubber nipple attached. It is then labelled carefully and stored in the icebox for future use.

Later bleeding from the ear veins of a rabbit can be facilitated by strapping the animal down on a flat, hot water bag. A technical point of great simplicity but which helps to make the sort of cut in the vein which favors free bleeding, consists in taking a pointed steel writing pen, breaking off one of the prongs and plunging the stilette thus made straight into the vein in a direction toward the heart. The entry thus made through the wall of the vein does not easily collapse and very free bleeding results.

To bleed a rabbit from the carotid the rabbit is strapped down on its back on a dissecting board and ether administered. A 

central incision along the neck above the trachea is made, and the carotid will be found lying very close to the trachea on either side. A ligature is applied distally, the artery raised on the handle of a forceps and a bulldog clamp applied toward the ridge of the neck. A sterile glass canula can be inserted, but we have found that with a little skill it is quite easy to lift up the artery and hold it by its wall with a forceps in such a way that the blood stream is not blocked. The vessel is then cut, the clamp removed, and by aiming the artery with the forceps in which it is held the stream of blood can be directed into a sterile test tube. In this way rabbits are usually bled until distinct respiratory distress ensues and the stream of blood ceases, the blood coming in drops. The clamp is then applied, the vessel tied and the rabbit sewed up aseptically. Such a rabbit can be kept alive and further used after recovery for continuation of the immunization. ${ }^{1}$

The bleeding of guinea pigs from the carotid is in every way similar, though a little more difficult than the bleeding of rabbits. When guinea pigs are bled, as they will be for the purpose of obtaining complement or alexin, it is necessary to do this carefully in order to obtain the best results. The blood is best taken into large sterile test tubes with as little violence as possible in order that there may be no breaking up of blood cells with consequent hemolysis. It is best to take the blood the evening before it is to be used, to allow it to clot in the test tube and then to separate the clot very gently from the sides of the tube. The tube should then be set aside in the refrigerator at a low temperature $\left(1-4^{\circ} \mathrm{C}\right.$. $)$. The rapidity with which complement degenerates at higher temperatures is generally underestimated. The following day the serum is pipetted away from the clot.

Some observers believe that complement increases in potency on standing for some hours on the clot. This was the contention of Henderson-Smith, though it has recently been contradicted by Addis and others. It is a good practice to obtain it in this way, however, because blood so taken is apt to be clearer and freer from hæmolysis than blood centrifugalized immediately after clotting. Although a slight tinge of hæmolysis does not

1 Intravenous injections of 10 to 20 c.c. of warm salt solution will of ten help to keep such animals alive. 

render blood useless for hæmolytic purposes, nevertheless the products of hæmolysis do affect the hæmolytic reaction and it is best to have an entirely clear alexin for use.

The technique of bleeding of sheep or other large animals has been described on page 2 .

\section{LESSON II}

\section{BACTERICIDAL POWER OF NORMAL SERUM}

Normal blood plasma or serum possesses the power of killing bacteria. Not all bacteria are equally susceptible to this effect. Some, like the Gram-positive cocci, the anthrax bacillus, and others, are probably killed in the circulation only by the cooperation of serum and leucocytes in phagocytosis. When the serum is heated to $56^{\circ} \mathrm{C}$., its bactericidal power is suspended.

Reagents :

1. Fresh normal rabbit serum, unheated.

2. Bacillus typhosus - 24-hour broth culture diluted 1-5000 in sterile salt solution.

3. Sterile salt solution.

The materials in this experiment must be measured with sterile pipettes and placed in sterile test tubes, with care to avoid contamination during the process of the experiment.

(a) Place 0.5 c.c. of normal rabbit serum in each of two sterile test tubes and heat one tube for half an hour at $56^{\circ} \mathrm{C}$. Then set up the following preparations in sterile plugged test tubes:

1. Normal rabbit serum 0.5 c.c. + Typhoid broth (1-5000) 0.5 c.c. ${ }^{1}$ (fresh)

2. Normal rabbit serum 0.5 c.c. + Typhoid broth (1-5000) 0.5 c.c. (heated)

3. Salt solution 0.5 c.c. + Typhoid broth (1-5000) 0.5 c.c.

1 To make dilutions for this and other purposes proceed as follows :

1. 1 c.c. of original substance to 9 c.c. of salt solution $=1-10$

2. 1 c.c. of dilution (1.) to 9 c.c. of salt solution $=1-100$

3. 1 c.c. of dilution (2.) to 4 c.c. of salt solution $=1-500$

4. 1 c.c. of dilution (3.) to 1 c.c. of salt solution $=1-1000$

5. 1 c.c. of dilution (4.) to 4 c.c. of salt solution $=1-5000$

This illustrates the general method, which ean be shortened or lengthened by longer or smaller intervals as the particular occasion requires. 

(b) Place the tubes in the incubator for two hours, and then pour into each tube a tube of agar which has been melted in boiling water and cooled to $42^{\circ} \mathrm{C}$. Pour the entire contents of each tube into a sterile Petri dish. When the plates are hardened, place them in the incubator in an inverted position, to be observed at the following lesson. The plates made from tubes 2 and 3 will show an enormous number of minute typhoid colonies after incubation. The plate from tube 1 will be sterile or may show a few large colonies.

\section{HEMOLYTIC AND HAMAGGLUTINATIVE POWER OF NORMAL SERUM}

The normal blood serum of many animals has hæmolytic and hæmagglutinative action upon the red blood cells of animals of some other species. This hæmolytic action, like the bactericidal action, is lost when the serum is heated to $56^{\circ} \mathrm{C}$. The hæmagglutinating property, on the other hand, is relatively resistant to heat and is not destroyed until the serum is heated to $70^{\circ} \mathrm{C}$. or above. Such a hæmolytic normal serum acts only on the erythrocytes of certain other species, sometimes upon 2 or 3 varieties with differing intensity. Thus goat serum is strongly hæmolytic for rabbit cells - less so for those of guinea pigs. Dog serum contains a relatively large amount of normal hæmolysin for most cells used in laboratory work. Guinea pig cells are highly susceptible, and human cells relatively resistant to hæmolysis by dog serum.

Reagents :

1. Fresh dog serum.

2. $2 \%$ suspension of washed guinea pig cells.

3. $2 \%$ suspension of washed human cells.

4. Salt solution.

Place 0.25 c.c. of dog serum in a test tube and heat for one half hour in water bath at $56^{\circ} \mathrm{C}$. Bring up volume to 2.5 c.c. with normal salt solution. Prepare a similar 1-10 dilution of unheated dog serum. Set up the following experiment in half-inch tubes : 

1. Dog serum unheated (1-10) 0.5 c.c. + Guinea pig cells $2 \% \quad 0.5$ c.c.

2. Dog serum unheated (1-10) 0.5 c.c. + Human cells $2 \% \quad 0.5$ c.c.

3. Dog serum heated $(1-10) \quad 0.5$ c.c. + Guinea pig cells $2 \% \quad 0.5$ c.c.

4. Dog serum heated (1-10) 0.5 c.c. + Human cells $2 \% \quad 0.5$ c.c.

5. Salt solution $\quad 0.5$ c.c. + Guinea pig cells $2 \% \quad 0.5$ c.c.

6. Salt solution $\quad 0.5$ c.c. + Human cells $2 \% \quad 0.5$ c.c.

Incubate the tubes one hour at $37^{\circ} \mathrm{C}$. in water bath, observing changes in cells at intervals of $5,10,15,30$, and 60 minutes. Tabulate the results. Tube 1 should show prompt hæmolysis; tube 3 should show agglutination of the cells. In tubes 2 and 4 there should be no observable change in the cells in most samples of dog serum.

Each student needs: 10 1/2-inch test tubes, test tube rack, 5 one-c.c. pipettes, 1 five-c.c. pipette.

\section{LESSON III}

\section{HAMOLYSIS. (EHRLICH AND MORGENROTH EXPERI- MENTS)}

1. To a group of students is assigned the task of bleeding a sheep from the jugular vein into a flask containing glass beads. After defibrination the cells are washed three times in salt solution and a 5 per cent suspension of the well-packed sediment is made ( 1.0 c.c. of sediment and 19.0 c.c. of salt solution).

2. To another group of students is assigned the bleeding of guinea pigs from the carotid artery into centrifuge tubes. The blood is allowed to clot, this clot is "rimmed" and the serum separated. The process may be hurried by centrifugation. The serum is then diluted, 1 part of serum to 9 parts of salt solution.

3. Immune rabbit serum (lytic for sheep cells) will be given out diluted. ${ }^{1}$ This serum has been heated for one half hour at $56^{\circ} \mathrm{C}$. before dilution, in order to destroy its alexin or complement. This is done so that no unknown amount of complement may be present in the final tests.

All these materials must be prepared before the regular class period, as the experiments themselves consume several hours. Provided the guinea pig serum is kept very cold $\left(0^{\circ}-4^{\circ} \mathrm{C}\right.$.), all the materials can be prepared the preceding day.

1 In order to save time in the course an immune serum previously prepared by the instructor is used here. The immune hrmolytic serum whose preparation was begun by the students in Lesson $I$ is to be titrated later and used for the. lessons on complement fixation. 



\section{Experiment 1}

To Show that Red Blood Cells will absorb Amboceptor but NoT CoMplement

Set up two mixtures in centrifuge tubes as indicated below:

$A$. Sheep cells and heated immune rabbit serum

$B$. Sheep cells and fresh normal guinea pig serum.

Incubate for 30 minutes at $37 \mathrm{C}$, then centrifugalize and remove the supernatant fluid, using a capillary pipette with rubber nipple.

Wash the sediment once in salt solution.

Resuspend the washed sediment in each tube in 3 c.c. salt solution. Add the reagents as indicated and incubate for one hour at $37 \mathrm{C}$., observing at short intervals. Tabulate the results.

\section{Tube A}

Sheep cells $5 \%$. . . . . . . . . . 1.0 c.c.

Inactivated immune rabbit serum ${ }^{1}$. . . . 1.0 c.c.

Incubate 30 minutes at $37^{\circ} \mathrm{C}$., centrifugalize, remove the supernatant fluid to another tube and wash the sediment.

We now have 2 tubes - one (Tube 1) containing the supernatant fluid, the other (Tube 2) the sediment from the original Tube A. To these tubes add reagents as follows:

\section{Tube 1}

(Supernatant fluid from

Tube A) . . . . 2.0 c.c.

Guinea pig serum (1-10) 1.0 c.c.

Sheep cells $5 \%$. . 1.0 c.c.

\section{Tube 2}

(Sediment from Tube A resuspended in salt solution) . . . . . 3.0 c.c. Guinea pig serum (1-10) 1.0 c.c.

\section{Incubate and observe.}

In which of the two does hæmolysis take place? What conclusion as to the reaction that has taken place in the original mixture in Tube A can you draw from this?

\section{Tube B}

Sheep cells $5 \%$. . . . . . . . . . 1.0 c.c.

Guinea pig serum (1-10) • • • . . . 1.0 c.c.

Incubate 30 minutes at $37^{\circ} \mathrm{C}$., centrifugalize, remove supernatant fluid to another tube and wash sediment.

${ }^{2}$ Diluted by the instructor so as to contain two hemolytic units in 1 c.c. 

Then, as in the preceding case, we have two tubes to which the following additions are made:

\section{Tube 1}

(Supernatant fluid from Tube B) about . . .

Immune rabbit serum Sheep cells $5 \% \quad$. . 1.0 c.c.

\section{Tube 2}

Incubate and observe.

In which tube does hæmolysis take place? Contrast this with results in Tube $\mathrm{A}$ and draw conclusions.

\section{Experiment 2}

To Show that at $0^{\circ} \mathrm{C}$. Cells will absorb Amboceptor alone From a Mixture of Amboceptor and Complement

The same reagents will be used in this as in the preceding experiment. The three reagents will first be cooled in ice water and then be mixed in a cold centrifuge tube, and allowed to stand at $0^{\circ} \mathrm{C}$. for an hour. With proper care this can easily be done in a battery jar filled with cracked ice and brine.

The success of the experiment depends on having the reagents and the centrifuge tube and metal holder thoroughly cooled in ice water before the mixture is made and in centrifugalizing and removing the supernatant fluid before they have time to regain the temperature of the room. The protocol for this experiment is given below :

Place centrifuge tube in holder in a cup of cracked ice and water and add :

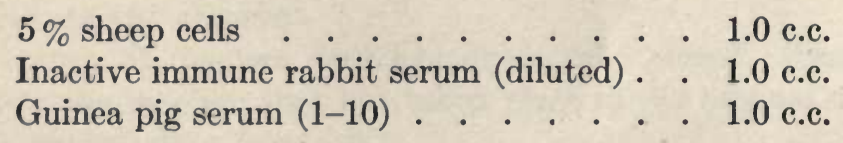

After twenty minutes the tube is centrifugalized, the supernatant fluid removed and half of it placed in each of two small test tubes. The sediment is to be washed once in cold salt solution, resuspended in 4 c.c. of salt solution and half of this suspension placed in each of two small test tubes.

We now have four tubes - two of which contain washed sediment and two of which contain supernatant fluid of the original mixture. To these the following additions are now made: 



\section{Tube 1}

Supernatant fluid . . . . . . . . . 1.5 c.c.

Fresh guinea pig serum $1-10$ (complement) 0.5 c.c. Washed sheep cells $5 \%$. . . . . . . 0.5 c.c.

Tube 2

Supernatant fluid . . . . . . . . 1.5 c.c.

Immune rabbit serum $\quad . \quad . \quad . \quad . \quad . \quad .0 .5$ c.c.

Washed sheep cells $5 \%$. . . . . . . 0.5 c.c.

Tube 3

Sediment . . . . . . . . . 2.0 c.c.

Guinea pig serum 1-10 . . . . . 0.5 c.c.

Tube 4

Sediment . . . . . . . . . . . 2.0 c.c.

Immune rabbit serum . . . . . . . 0.5 c.c.

Incubate one hour at $37^{\circ} \mathrm{C}$, observing at frequent intervals.

The results will show that the hæmolytic amboceptor or sensitizer present in the original heated immune serum was bound by the cells at $0^{\circ} \mathrm{C}$. - but at this low temperature the complement or alexin remained not only inactive but unbound and free.

\section{APPaRatus}

Each student will require :

3 graduated centrifuge tubes

8 half-inch test tubes

9 one c.c. pipettes

1 test tube rack

1 bottle of salt solution

1 jar of cracked ice (pint measure)

1 rubber nipple and capillary pipette

The class will require :

1 outfit for bleeding sheep :

needle,

tourniquet,

razor and scissors,

bottle of tincture of iodine, sterile flask containing beads. 

1 or more outfits for bleeding guinea pigs :

scissors,

forceps,

ether cone,

centrifuge tubes.

\section{Materials}

Each student will require :

Washed sheep cells $5 \%$. . . . . 6.0 c.c.

Guinea pig serum $1-10$. . . . . . 6.0 c.c.

Inactive serum of rabbit immunized against sheep cells, diluted so that each c.c. contains 2-4 hæmolytic doses . . . . 6.0 c.c.

\section{LESSON IV}

\section{QUANTITATIVE RELATIONSHIPS OF AMBOCEPTOR AND COMPLEMENT}

\section{Methods of Titration}

THE hæmolysis of red cells by specific sensitizer [or amboceptor] and alexin [or complement] is a delicately quantitative reaction in which very definite amounts of the three substances are necessary to produce a complete reaction. As a unit of red cells, one cubic centimeter of a 5 per cent suspension of red cells is conveniently taken. This means that the cells after washing are sedimented in the centrifuge and 1.0 c.c. of the sediment is added to 19.0 c.c. of salt solution. (Some investigators have worked with suspensions representing 5 per cent of the original blood. Assuming the cells to constitute 50 per cent of the blood volume, suspensions so made up are just half as concentrated as the ones here used. In all the work here described the term 5 per cent suspension is taken to represent 5 per cent by actual volume of erythrocyte sediment in salt solution.)

Definite amounts of sensitizer and of alexin are necessary to lake completely one cubic centimeter of such a suspension, and it is necessary for accurate experimentation to determine for each set of reagents the minimal amounts necessary to accomplish 

this purpose. It must be remembered that no two suspensions of red cells are exactly alike - since it is impossible to measure them with absolute accuracy, and since the resistance of erythrocytes to hæmolysis, even when taken from the same animal on different days, may vary. No two fresh sera, moreover, are entirely alike in alexic activity. The experiments given below will demonstrate the method of determining by titration the minimal hæmolytic dose of complement and amboceptor; they will also demonstrate that this dose varies reciprocally, that is, that with a small amount of complement a relatively larger amount of amboceptor will be necessary to cause complete hæmolysis, whereas with a large amount of complement only a small amount of amboceptor is necessary. There is, however, no simple proportionality.

\section{Experiment 1}

Titration of Hzemolytic Sensitizer or Amboceptor. DeterminaTION OF UNIT

The unit of sensitizer, or amboceptor, is the smallest amount which will cause complete laking of a unit of cells (1.0 c.c. of a 5 per cent emulsion) ${ }^{1}$ in one hour, in the presence of an excess of complement.

As the degree of dilution is an important factor it is necessary that the volume of all the tubes be brought to a uniform standard before the reaction actually begins. For this reason the reagents are added in the following order :

1. Sensitizer [amboceptor]

2. Alexin [complement]

3. Saline to make all volumes equal

4. Cells

A control tube must be set up to prove that the amount of alexin or complement used will not of itself lake the cells.

1 For convenience or economy $0.5,0.25$ or 0.1 c.c. of 5 per cent red cells are sometimes taken as the unit, and in such cases the unit of amboceptor and complement must be proportionately reduced. For the sake of uniformity results so obtained can easily be transposed to terms of the 1 c.c. unit, as is of ten done in reporting Wassermann tests. 

Set up the following tests:

\begin{tabular}{|c|c|c|c|c|}
\hline & Immune Serum & (Sensitizer) & Complemer & \\
\hline $\begin{array}{r}\text { Tube } 1 . \\
2 . \\
3 . \\
4 . \\
5 . \\
6 . \\
7 . \\
8 . \\
9 .\end{array}$ & $\begin{array}{l}\text { (diluted 1-100) } \\
\text { (diluted 1-100) } \\
\text { (diluted 1-1000 } \\
\text { (diluted 1-1000 } \\
\text { (diluted 1-1000 } \\
\text { (diluted 1-1000 } \\
\text { (diluted 1-1000 } \\
\text { (diluted 1-1000) } \\
\text { (diluted 1-1000) }\end{array}$ & $\begin{array}{l}0.5 \text { c.c. } \\
0.2 \text { c.c. } \\
1.0 \text { c.c. } \\
0.5 \text { c.c. } \\
0.4 \text { c.c. } \\
0.3 \text { c.c. } \\
0.2 \text { c.c. } \\
0.1 \text { c.c. } \\
0.0 \text { c.c. }\end{array}$ & $\begin{array}{l}0.05 \text { c.c. } \\
0.05 \text { c.c. } \\
0.05 \text { c.c. } \\
0.05 \text { c.c. } \\
0.05 \text { c.c. } \\
0.05 \text { c.c. } \\
0.05 \text { c.c. } \\
0.05 \text { c.c. } \\
0.05 \text { c.c. }\end{array}$ & $\begin{array}{l}\text { Add saline } \\
\text { to } 2 \text { c.c. } \\
\text { and then } \\
0.5 \text { c.c. of } \\
\text { the red cell } \\
\text { emulsion. }{ }^{1}\end{array}$ \\
\hline
\end{tabular}

\section{Series 2}

\section{Immune Serum (Sensitizer) Complement}

Tube 1. (diluted 1-100) 0.5 c.c.

2. (diluted 1-100) 0.2 c.c.

3. (diluted 1-1000) 1.0 c.c.

4. (diluted 1-1000) 0.5 c.c.

5. (diluted 1-1000) 0.4 c.c.

6. (diluted 1-1000) 0.3 c.c.

7. (diluted 1-1000) 0.2 c.c.

8. (diluted 1-1000) 0.1 c.c.

9. (diluted 1-100) 0.5 c.c.

(Sensitizer Control)

0.02 c.c.

0.02 c.c.

0.02 c.c. Add saline

0.02 c.c. to 2 c.c.

0.02 c.c. $\}$ and then

0.02 c.c. 0.5 c.c. of

0.02 c.c. the red cell

0.02 c.c. emulsion.

0.00 c.c.

\section{Series 3}

Immune Serum (Sensitizer) Complement

Tube 1. (diluted 1-100) 0.5 c.c.

2. (diluted 1-100) 0.2 c.c.

0.01 c.c.

3. (diluted 1-1000) 1.0 c.c.

0.01 c.c.

4. (diluted 1-1000) 0.5 c.c.

5. (diluted 1-1000) 0.4 c.c.

0.01 c.c. Add saline

6. (diluted 1-1000) 0.3 c.c.

7. (diluted 1-1000) 0.2 c.c.

8. (diluted 1-1000) 0.1 c.c.

9. (diluted 1-1000) 0.0 c.c.

(Salt Solution Control)

0.01 c.c. to 2 c.c.

0.01 c.c. and then

0.01 c.c. 0.5 c.c. of

0.01 c.c. the red cell

0.01 c.c. emulsion.

0.00 c.c. J

${ }^{1} \mathrm{~A}$ half c.c. instead of one c.c. is used in order to save materials. The amounts of complement and amboceptor needed are of course half those that would be needed for 1 c.c. of cells. 

In measuring $0.05,0.02$ and 0.01 c.c. of complement it is best to use a half c.c., .2 c.c. and .1 c.c. of a 1-10 dilution. Shake each tube thoroughly when all the reagents have been added. Incubate one hour in water bath at $37^{\circ} \mathrm{C}$. and record by + or - signs hæmolysis at 15 , 30 and 60 minutes in the following protocol:

\begin{tabular}{|c|c|c|c|c|c|c|c|c|c|}
\hline & \multicolumn{9}{|c|}{ ImMUNe Serum (Sensitizer or Amboceptor) } \\
\hline & \multicolumn{2}{|c|}{ Diluted 1-100 } & \multicolumn{7}{|c|}{ Diluted $1-1000$} \\
\hline $\begin{array}{l}\text { Complement } 0.05 \\
\text { Complement } 0.1 \\
\text { Complement } 0.2\end{array}$ & 0.5 & 0.2 & 1.0 & 0.5 & 0.4 & 0.3 & 0.2 & 0.1 & 0.0 \\
\hline
\end{tabular}

Indicate what the unit is in this case.

The tabulation given for final record is the manner in which an experiment of this kind is best recorded by experienced workers. We have inserted the simpler protocols of the three series before this in order to make the purpose of this experiment and its execution a little more easy.

(On account of the costliness of guinea-pig serum students should divide themselves into groups of 3 , of whom each student should set up one series of amboceptor dilutions with one of the complement quantities.)

Individual guinea pigs vary in the complementary activity of their serum. For accurate hæmolytic experiments, however, it is necessary to use a constant amount of complement activity. For this reason the unit of amboceptor (which if carefully preserved remains constant over long periods) is taken as a standard to which the strength of each fresh complement serum is adjusted.

Strictly speaking, the unit of complement should be that amount which gives complete laking with one unit of cells and one unit of amboceptor. In practice, however, this turns out to be too large an amount, and for this reason complement is usually titrated with two units of amboceptor. The unit of complement then may be defined as the least amount that completely hemolyses 1.0 c.c. of a five per cent emulsion of red cells in the presence of two units of amboceptor in thirty minutes in the water bath. If the test is done with smaller quantities of red cells the unit is correspondingly smaller. Set up titrations with both two and one units as follows: 



\begin{tabular}{|c|c|c|c|}
\hline TUBE & CoMpLement $1-10$ & & AMBOCEPTOR \\
\hline $\begin{array}{l}1 \\
2 \\
3 \\
4 \\
5\end{array}$ & $\begin{array}{l}0.5 . c . c . \\
0.4 \\
0.3 \\
0.2 \\
0.1\end{array}$ & $\left.\begin{array}{l}2 \text { units } \\
2 \text { units } \\
2 \text { units } \\
2 \text { units } \\
2 \text { units }\end{array}\right\}$ & $\begin{array}{l}\text { Add } \\
\text { Saline to } 2 \text { c.c. } \\
5 \% \text { cells, } 0.5 \text { c.c. }\end{array}$ \\
\hline $\begin{array}{r}6 \\
7 \\
8 \\
9 \\
10\end{array}$ & $\begin{array}{l}0.5 \\
0.4 \\
0.3 \\
0.2 \\
0.1\end{array}$ & $\left.\begin{array}{ll}1 & \text { unit } \\
1 & \text { unit } \\
1 & \text { unit } \\
1 & \text { unit } \\
1 & \text { unit }\end{array}\right\}$ & $\begin{array}{l}\text { Add } \\
\text { Saline to } 2 \text { c.c. } \\
5 \% \text { cells, } 0.5 \text { c.c. }\end{array}$ \\
\hline
\end{tabular}

Incubate. Read results at 15,30 and 60 minutes.

(Indicate unit found.)

It should be remembered that even with these two reagents, complement and amboceptor, titrated, the amounts determined might vary somewhat if cells from another sheep or taken from this sheep on another day were used - since the resistance of the cells is also a variable factor.

In many experiments it is expedient to use red cells previously sensitized with a definite number of amboceptor units. In order to do this the following method is employed. The red cells after washing are taken up in salt solution in a definite concentration which for ordinary work is $\mathbf{5}$ per cent. Inactivated immune serum (amboceptor or sensitizer) diluted in salt solution is then added so that the required number of previously determined hæmolytic units shall be present for every unit ( 1.0 c.c. of 5 per cent) of red cells. Therefore, supposing that 0.001 c.c. of the immune serum was found to be one hæmolytic amboceptor unit, 1.0 c.c. of the 1-1000 dilution of this serum added to 1.0 c.c. of a 5 per cent emulsion of red cells would sensitize them with one unit. Having made such a mixture and having given it $\mathbf{1 5}$ minutes to allow the union to take place, every 2.0 c.c. would represent 1.0 c.c. of 5 per cent red cells and 1 unit of amboceptor united. Or if desired the cells could be centrifugalized, washed, and made up to the original concentration of 5 per cent. On this principle any number of units up to the maximum absorption power can be added to the red cells. As we approach the maximum absorption power of amboceptor by red cells it is always well to centrifugalize and reëmulsify the red cells so that our experiment may not be confused by the presence of excessive unabsorbed amboceptor. 

Each student needs:

10 c.c. of $5 \%$ sheep cells

2 c.c. amboceptor (diluted 1-100)

2 c.c. complement undiluted, for each three students

1 test tube rack

20 half-inch test tubes

4 1-c.c. pipettes, and flask salt solution

$4 \quad \frac{3}{4}$-inch test tubes

\section{LESSON V}

\section{QUANTITATIVE RELATIONS OF AMBOCEPTOR AND COMPLE- MENT (Continued)}

\section{Experiment 1}

The Activity of Complement Depends to Some Extent on Its Concentration and not only on the Total Amount Present

A 25 per cent suspension of washed sheep cells is made.

A series of tubes is set up (if necessary by instructor) in which the minimal amount of amboceptor necessary to lake 0.1 c.c. of these cells in the presence of 0.05 c.c. of undiluted complement and in a total volume of 1.0 c.c. is determined. The hæmolytic serum (amboceptor) is then diluted so that this minimal amount is contained in 0.1 c.c.

The student then mixes 2.0 c.c. of this amboceptor dilution with 2.0 c.c. of the 25 per cent red cell suspension. He then determines, in the following preliminary titration, the minimal amount (unit) of complement which will lake 0.1 c.c. of these cells in one hour, in a total volume of 1 c.c.

\begin{tabular}{|c|c|c|c|}
\hline & Guinea-pig Serum 1-10 & $\begin{array}{l}\text { SENSiTIzEd CELLS } \\
\text { (.05 C.C. CELLS +..55 C.C. } \\
\text { OF AMBOCEPTOR) }\end{array}$ & SAline UP TO 1.0 C.C. \\
\hline $\begin{array}{l}\text { Tube } 1 \\
\text { Tube } 2 \\
\text { Tube } 3 \\
\text { Tube } 4 \\
\text { Tube } 5 \\
\text { Tube } 6 \\
\text { Tube } 7 \\
\text { Tube } 8\end{array}$ & $\begin{array}{l}0.15 \text { c.c. } \\
0.2 \\
0.25 \\
0.3 \\
0.4 \\
0.5 \\
0.0 \\
.5\end{array}$ & $\begin{array}{l}0.1 \text { c.c. } \\
0.1 \text { c.c. } \\
0.1 \text { c.c. } \\
0.1 \text { c.c. } \\
0.1 \text { c.c. } \\
0.1 \text { c.c. } \\
0.1 \\
.05 \text { unsensi- } \\
\text { tized cells }\end{array}$ & $\begin{array}{l}.75 \text { c.c. } \\
.7 \\
.65 \\
.6 \\
.5 \\
.4 \\
.9 \\
.45\end{array}$ \\
\hline
\end{tabular}

Then with 1, 5, and 10 times this minimal amount in the tubes as indicated in the protocol the experiment is set up. The protocol given below is constructed on the supposition that, in the above titration, 0.2 c.c. of a 1 to 10 dilution of complement was the smallest amount of the complement which gave complete laking. 



\begin{tabular}{|c|c|c|c|}
\hline & $\begin{array}{c}\text { Guinea Pig Serum } \\
\text { in } 10\end{array}$ & SALT SOLUTION UP TO & $\begin{array}{l}\text { REsULTING DILUTION } \\
\text { of GUINEA PIG SERUM }\end{array}$ \\
\hline Tube 1 & 0.2 с.с. & 1.0 c.c. & 1 in 50 \\
\hline Tube 2 & 0.2 & 2.0 & 1 in 100 \\
\hline Tube 3 & 0.2 & 5.0 & 1 in 250 \\
\hline Tube 4 & 0.2 & 10.0 & 1 in 500 \\
\hline Tube 5 & 1.0 & 1.0 & 1 in 10 \\
\hline Tube 6 & 1.0 & 5.0 & 1 in 50 \\
\hline Tube 7 & 1.0 & 10.0 & 1 in 100 \\
\hline Tube 8 & 1.0 & 20.0 & 1 in 200 \\
\hline Tube 9 & 2.0 & 5.0 & 1 in 25 \\
\hline Tube 10 & 2.0 & 10.0 & 1 in 50 \\
\hline Tube 11 & 2.0 & 20.0 & 1 in 100 \\
\hline
\end{tabular}

To each tube add 1 unit ( 0.1 c.c.) of cells previously sensitized with 1 unit of amboceptor.

Calculate the concentration of complement in the tubes used in the preliminary complement titration, and compare the results. If the activity of complement does depend upon the concentration, complete laking should occur in one hour in those tubes of the second series which contain a dilution of guinea pig serum equal to that in the first tube of the first series which showed complete hæmolysis.

\section{Experiment 2}

The Activity of Sensitizer or Amboceptor Depends on Its Total Amount and not on Its Concentration

Suspend 1 unit $(0.05$ of $25 \%)$ of cells in varying amounts $(1,5,10$, 20 c.c.) of salt solution.

To each tube add 1 unit of amboceptor.

Mix and keep at $37^{\circ} \mathrm{C}$. for one half hour.

Centrifugalize.

To the sediment in each tube add 1 unit of complement, as previously determined, and sufficient salt solution to bring the volume to 1 c.c.

Incubate.

All tubes should show complete hæmolysis in 1 hour if the cells have absorbed the entire unit of amboceptor.

Each student needs:

\section{2 c.c. of $25 \%$ sheep cells} (about) 2 c.c. of undiluted complement

25 units of amboceptor Flask of saline 4 one-c.c. pipettes
1 ten-c.c. pipette

2 test tube racks for $12 \frac{3}{4}$-inch test tubes

$20 \frac{3}{4}$-inch test tubes

1 fifty-c.c. centrifuge tube

3 fifteen-c.c. centrifuge tubes

$6 \frac{1}{2}$-inch test tubes 



\section{LESSON VI}

\section{THE UNION OF IMMUNE-BODY (AMBOCEPTOR OR SENSI- TIZER) AND CELLS}

\section{Dissociation of Amboceptor (Muir)}

RED cells have a very great affinity for their specific immunebody. They can absorb a great number of units. Nevertheless at $37^{\circ} \mathrm{C}$. corpuscles containing multiple doses of amboceptor give off a certain amount to the surrounding fluid when it is free of it. There appears to be an equilibrium between combined and free immune-body. This can be illustrated by the following experiment :

To 1.5 c.c. of a 5 per cent emulsion of sheep corpuscles is added inactivated hæmolytic serum so that there shall be 20 units of amboceptor ${ }^{1}$ to every 0.5 c.c. of cells. (The student should calculate and make dilutions for this purpose after being told the unit of the hæmolytic serum given him.)

This mixture is allowed to stand at room temperature for 30 minutes.

Centrifugalize and set aside the supernatant fluid. This is Tube $(a)$.

Wash the cells obtained in the sediment of the preceding centrifugation three times and set aside the salt solution remaining as supernatant fluid of the last washing. This is Tube (b).

Make the suspension of red cells up to the original volume by the addition of saline and incubate this at $42^{\circ} \mathrm{C}$. for one hour. Then centrifugalize and set aside the supernatant fluid of this, which constitutes Tube $(c)$.

Make the sediment of the cells obtained in the preceding up to 1.5 c.c. Shake. Remove 0.5 c.c. and add to it 1.0 c.c. of 10 per cent fresh guinea pig complement. This is Tube $(d)$.

To $(a),(b)$ and $(c)$, each, add 0.5 c.c. of 5 per cent sheep corpuscles and .5 c.c. of complement (10 per cent fresh guinea pig serum in salt solution).

All four tubes are incubated at $37^{\circ} \mathrm{C}$. for one hour.

Record the degree of laking in each tube.

Tube (a) will show how much of the 20 units of amboceptor failed to be absorbed. The exact amount could be determined by titration, which, however, would needlessly prolong the experiment and add nothing to the illustration of the principle.

1 The unit here is the minimal amount which lakes 0.5 c.c., not 1 c.c., of cells. If Experiments 1 and 3 of this lesson are to be done on the same afternoon it is well to sensitize a considerable amount of cells at one time. 

Tube (b) will show whether the three washings were sufficient to remove all amboceptor from the fluid bathing the cells. Any excess of amboceptor remaining unattached to the cells after the washing would show in the supernatant fluid by laking.

Tube (c) will show how much, if any, amboceptor was dissociated after one hour at $37^{\circ} \mathrm{C}$.

\section{Velocity of Amboceptor Absorption}

Red cells absorb their homologous immune-body very rapidly. A knowledge of this is of great importance as the following experiments show.

\section{A}

Take 3 c.c. of 5 per cent sheep corpuscles in a wide test tube and add 3 c.c. of diluted amboceptor drop by drop, shaking constantly (the dilution of the amboceptor is such that 1 unit is contained in 0.5 c.c. ; the unit here is taken as the minimal amount which lakes 0.5 c.c. of cells).

B

Take 3 c.c. of diluted amboceptor and add 3 c.c. of 5 per cent sheep cells drop by drop, shaking constantly.

Set up two parallel series of five tubes each containing varying amounts of guinea pig serum (1-10).

Series 1

\begin{tabular}{|c|c|c|c|}
\hline TUBE & $\begin{array}{l}\text { Guinea Pia Serom } \\
\text { Diloted 1-10 } \\
\text { (Complement) }\end{array}$ & $\begin{array}{c}\text { SALT SolUtion (TO } \\
\text { MAKE ALL VolUMEs } \\
\text { EQUAL) }\end{array}$ & MixtUre A \\
\hline $\begin{array}{l}1 \\
2 \\
3 \\
4 \\
5\end{array}$ & $\begin{array}{l}0.75 \text { c.c. } \\
0.5 \text { c.c. } \\
0.4 \text { c.c. } \\
0.3 \text { c.c. } \\
0.2 \text { c.c. }\end{array}$ & $\begin{array}{l}0.0 \text { c.c. } \\
0.25 \text { c.c. } \\
0.35 \text { c.c. } \\
0.45 \text { c.c. } \\
0.55 \text { c.c. }\end{array}$ & $\begin{array}{l}1.0 \text { c.c. } \\
1.0 \text { c.c. } \\
1.0 \text { c.c. } \\
1.0 \text { c.c. } \\
1.0 \text { c.c. }\end{array}$ \\
\hline
\end{tabular}

Series 2

Duplicate above with mixture B.

Incubate one hour and compare results.

The observed differences are probably explained by the fact that the first cells which are added to B absorb nearly all the amboceptor, leaving insufficient to sensitize the last cells added. 



\section{Liberation of AMboceptor in Hamolysis}

When red cells containing several hæmolytic doses of amboceptor are laked by a not excessive amount of complement, some of the amboceptor is liberated in the solution.

To 2.0 c.c. of 5 per cent sheep cells add sufficient amboceptor so that there will be 20 units for every unit ( 0.5 c.c.) of 5 per cent sheep cells. Allow to stand for one half hour. Centrifuge and wash with saline three times and after the third washing make the volume again up to 2.0 c.c.

To 1.0 c.c. of cells so sensitized add 1.0 c.c. of 10 per cent guinea-pig complement. Incubate one half hour. Then divide into two equal portions of 1.0 c.c. each. To the first portion add 0.5 c.c. of the sensitized cells and incubate again for one hour. Note whether hæmolysis of the added cells occurs. To the second portion add 0.5 c.c. of untreated corpuscle suspension and 1.0 c.c. of 10 per cent complement. Hæmolysis, after incubation at $37 \frac{1}{2}$ degrees centigrade, will indicate that amboceptor was liberated by the laking of the sensitized cells during the first incubation and was taken up by the added cells in the second incubation.

How does the amount of amboceptor liberated compare with the amount dissociated by simple incubation without hæmolysis in Experiment 1 ?

\section{Each student needs :}

12 c.c. of $5 \%$ sheep cells

100 units of amboceptor

10 c.c. of complement (1-10)

Flask saline

4 one-c.c. pipettes

1 test tube rack for half-inch test tubes

1 graduated centrifuge tube

20 half-inch test tubes

3 three-quarter-inch test tubes

1 five-c.c. pipette

1 nipple pipette ${ }^{1}$

1 If experiments 1 and 3 of this lesson are to be done on the same afternoon, it is well to sensitize a considerable amount of cells at one time. 



\section{LESSON VII}

\section{PFEIFFER PHENOMENON}

VIRULENT cholera spirilla injected into the peritoneal cavity of a normal guinea pig proceed to multiply rapidly after a period of about half an hour, and the animal dies usually within 24 hours with symptoms of profound intoxication. The same spirilla injected into an animal which has been immunized by previous injections of killed spirilla or of sub-lethal doses of the living microörganisms become granular and in some cases swell, take on globular and vacuolated forms and gradually undergo lysis. The guinea pig in such cases recovers completely from the injection. This destruction of invading bacteria by the immune animal was termed by Pfeiffer "bacteriolysis." It has been observed with certain of the Gram-negative bacilli such as the typhoid and the dysentery bacillus, but is best observed in cholera. Similar lysis is observed if the spirilla are injected into a normal pig together with serum of an immunized guinea pig or rabbit.

For this experiment it is necessary to employ a virulent ${ }^{1}$ strain of cholera spirilla, since old laboratory cultures do not show the phenomenon sharply and rarely kill the guinea pigs in the controls.

The lethal dose of the particular strain of cholera used for the guinea pigs should be determined roughly before carrying out the experiment.

It is inadvisable to allow students, except in very small groups, to handle virulent cholera cultures, so that in carrying out this experiment, the preparation of the cholera suspension, the injection of the pig and the removal of specimens from the peritoneum, as described below, should be carried out by the instructor. The smears should be fixed immediately in 10 per cent formalin, after which they may be distributed to the members of the class for study.

Two pigs - one normal, the other previously immunized with cholera spirilla - are intraperitoneally injected with the determined dose, say a

${ }^{1}$ The strain must be recently isolated or one that has been passed through guinea pigs until it will kill in quantities of one loopful of an agar slant. 

twentieth of the emulsion obtrined from an agar slant, and after ten minutes a specimen of the peritoneal fluid is withdrawn for observation. This is done by shaving the left side of the abdomen of the pig, holding the pig, back down, on a tray. This can be done satisfactorily with the operator's left hand. The shaved surface of the skin is sterilized by wiping with 5 per cent carbolic, a small cut made through the skin, but not through the muscles, with a sharp pair of scissors. Then the sharp tip of a capillary pipette is inserted through the muscles and the peritoneum. If the pipette is held horizontally or with the open end depressed, a small amount of peritoneal fluid will run up into the capillary portion even if no suction is used. When sufficient amount of fluid [ 0.1 or 0.2 c.c.] is obtained, the pipette is withdrawn and the puncture covered with cotton soaked in carbolic solution.

A hang-drop preparation is made with a drop of this fluid and the remainder blown out into a watch glass. With a platinum loop a series of thin smears are made of this fluid on glass slides, allowing one slide for each member of the class, and as soon as the films are dried they are placed in Coplin jars containing a 10 per cent solution of formalin (4 per cent formaldehyde) for five minutes. They are then withdrawn, allowed to dry, and are stained by the students with methylene blue and studied under the oil immersion lens. The hang-drop preparation should be observed under a high-power dry lens and one preparation may be observed by the whole class.

Preparations are made in this way from the normal and immune pig ten minutes, thirty minutes, one hour and two hours respectively after injection. By the end of this period if a proper dose of the organisms has been injected, the spirilla will be found to have multiplied enormously in the peritoneal fluid of the normal animal, whereas in the smears made from the immune animal after thirty minutes to an hour the spirilla will appear granular or swollen, and after two hours, or, if the observation is followed that long, after three or four hours, will be found to have practically disappeared.

The two animals should be kept for observation after the experiment, and the unprotected animal will probably be found dead the next day.

The passive transference of bacteriolytic immunity to another animal by simultaneous injection of cholera spirilla and anti-cholera serum obtained from the rabbit immunized to cholera may be demonstrated in a similar way, and by this technic the strength of a bacteriolytic serum may be titrated by injecting series of guinea pigs with varying amounts of the serum. 

A type protocol of such an experiment is given below:

\begin{tabular}{|c|c|c|c|}
\hline $\begin{array}{l}\text { WEIGHT or } \\
\text { GUINEA PIG }\end{array}$ & $\begin{array}{c}\text { Dose of } \\
\text { BACTERIA } \\
\text { CHOLERA } \\
\text { SPIRILA }\end{array}$ & $\begin{array}{l}\text { AMOUNT OF } \\
\text { INACTIVATED } \\
\text { IMMONE SERUM }\end{array}$ & Result \\
\hline (1) $215 \mathrm{gm}$. & $2 \mathrm{mg}$. & 0.1 c.c. in 1 c.c. & Complete dissolution in less \\
\hline (2) $230 \mathrm{gm}$. & $2 \mathrm{mg}$. & 0.05 c.c. & $\begin{array}{l}\text { than one nour. Hives. } \\
\text { About the same as first. }\end{array}$ \\
\hline (3) $200 \mathrm{gm}$. & $2 \mathrm{mg}$. & 0.01 c.c. & $\begin{array}{l}\text { Somewhat slower than in other } \\
\text { two; a few unchanged spirilla } \\
\text { after } 1 \text { hour. Final dissolution. } \\
\text { Pig lives. }\end{array}$ \\
\hline (4) $245 \mathrm{gm}$. & $2 \mathrm{mg}$. & 0.005 c.c. & $\begin{array}{l}\text { Similar to (3) but complete } \\
\text { dissolution in } 2 \text { hours. Pig lives. }\end{array}$ \\
\hline (5) $220 \mathrm{gm}$. & $2 \mathrm{mg}$. & 0.001 c.c. & $\begin{array}{l}\text { After } 30 \text { minutes the spirilla } \\
\text { seem to have begun to multiply. } \\
\text { Dies with innumerable active } \\
\text { spirilla in peritoneum. }\end{array}$ \\
\hline $\begin{array}{l}\text { Normal Con- } \\
\text { trol }\end{array}$ & & & \\
\hline (6) $210 \mathrm{gm}$. & $2 \mathrm{mg}$. & $\begin{array}{l}0.1 \text { c.c. normal } \\
\text { inactive rab- } \\
\text { bit serum }\end{array}$ & $\begin{array}{l}\text { Very slight lysis at the begin- } \\
\text { ning. Soon rapid multiplication. } \\
\text { Dies. }\end{array}$ \\
\hline
\end{tabular}

\section{LESSON VIII}

\section{BACTERICIDAL TEST IN VITRO - STERN KORTE}

THE destruction of bacteria which takes place in the peritoneum of immune animals may also be demonstrated for certain species of bacteria in the test tube. Small quantities of typhoid bacilli, as shown in a previous experiment, are killed by exposure to certain normal sera such as those of the rabbit and the guinea pig. A more powerful action is observed in sera of animals immunized to the typhoid bacillus, and, as in the case of red cells, the immune body or sensitizer can be shown to be relatively thermostable in that it will act after exposure to $56^{\circ} \mathrm{C}$. for half an hour provided it is reactivated by the addition of a small amount of normal serum.

The bactericidal effect of immune serum shows more clearly than most other antibody phenomena the presence of a prezone,

1 The bacteria may be measured for such an experiment by standard loopfuls (one loop being equal to 2 milligrams), or by volume in emulsion with salt solution. 

that is, the fallure of the antibodies to act if present in excessive concentration. In the sera of artificially immunized animals or of typhoid patients amounts greater than 0.01 c.c. of a strongly immune serum are usually ineffective, the best results being obtained with amounts varying from 0.001 to 0.0001 c.c. in a volume of 1 c.c.

Since the inactivated immune serum must, of course, be reactivated by fresh normal serum used as complement or alexin, it is important to use an amount of the normal serum too small to be of itself bactericidal; and the first step to determine is the bactericidal power of the normal serum against the strain of bacteria to be used. On the other hand, to secure striking results it is necessary to use as large an amount of fresh normal serum as possible without entering the zone of normal bactericidal power. Normal rabbit serum is usually definitely bactericidal for typhoid bacilli in amounts ranging from 0.1 to 0.02 c.c. (in a total volume of 1 c.c.).

Reagents :

1. Anti-typhoid serum - serum of a rabbit immunized against typhoid bacilli obtained in sterile condition and heated at $56^{\circ} \mathrm{C}$. for half an hour.

2. Normal rabbit serum, which must also be sterile.

3. 24-hour broth culture of typhoid bacilli.

The glassware and salt solution used in the experiment must, of course, be sterile, and the reagents handled with care to avoid contamination during the setting up of the experiment.

\section{Tentative Schedule ${ }^{1}$}

Set up the following tubes:

\begin{tabular}{|c|c|c|c|c|}
\hline \multirow[b]{2}{*}{ TUBE } & \multicolumn{2}{|c|}{ IMMUNE SERUM } & \multirow{2}{*}{$\begin{array}{c}\text { SALT } \\
\text { SoLUTION }\end{array}$} & \multirow{2}{*}{$\begin{array}{l}\text { Normal RabBit } \\
\text { Serum } 1-50\end{array}$} \\
\hline & $\begin{array}{l}\text { Actual Quantity of the } \\
\text { Immune Serum }\end{array}$ & & & \\
\hline $\begin{array}{l}1 \\
2 \\
3 \\
4 \\
5 \\
6 \\
7 \\
8\end{array}$ & $\begin{array}{l}0.01 \text { c.c. } \\
0.002 \text { c.c. } \\
0.001 \text { c.c. } \\
0.0001 \text { c.c. } \\
20.01 \text { c.c. } \\
\text { None } \\
\text { None } \\
\text { None }\end{array}$ & $\begin{array}{l}0.5 \text { c.c. }(1-50) \\
0.1 \text { c.c. }(1-50) \\
0.5 \text { c.c. }(1-500) \\
0.05 \text { c.c. }(1-500) \\
0.5 \text { c.c. }(1-50) \\
-\quad- \\
-\quad-\end{array}$ & $\begin{array}{l}0.0 \text { c.c. } \\
0.4 \text { c.c. } \\
0.0 \text { c.c. } \\
0.45 \text { c.c. } \\
0.5 \text { c.c. } \\
0.5 \text { c.c. } \\
1.0 \text { c.c. } \\
1.0 \text { c.c. }\end{array}$ & $\begin{array}{l}0.5 \text { c.c. } \\
0.5 \text { c.c. } \\
0.5 \text { c.c. } \\
0.5 \text { c.c. } \\
-.5 \text { c.c. } \\
\text { _ }\end{array}$ \\
\hline
\end{tabular}

${ }^{1}$ By a previous test of the serum the instructor should adjust the schedule so that one or two tubes lie within the "killing" zone and others above and below it.

2 The serum in this control tube should be that amount which shows maximum bactericidal power when used with active serum. 

Add to each tube about 0.1 c.c. of a 24 hour broth culture of B. typhosus, diluted 1-500. This should be measured by making a mark on a sterile capillary pipette, filling accurately to this mark and discharging the contents against the side of the tube, close to the level of the fluid, being careful not to touch the upper portion. The actual amount used is unimportant, but precisely equal amounts must be added to each tube. Shake. Incubate the tubes two hours at $37^{\circ} \mathrm{C}$. At the end of this time convey two loopsful from each tube into melted and cooled agar tubes and pour plates in the usual way. Transfer of two loops from tube eight should also be made into agar in this way immediately after mixing without incubating.

In careful experiments, two additional controls, the one containing 0.5 c.c. of 1-50 normal serum, the other containing 0.5 c.c. of 1-50 immune serum without the addition of typhoid bacilli, should also be set up and transfers should be made from them into agar to prove the sterility of the reagents used. A successful experiment should show an enormous number of colonies, over 10,000 to the plate, in plates Nos. 5, 6 and 7 . Plate 8 should also show a large number of colonies, though perhaps less than the other controls. In plates 2 and 3 there should be very few colonies or none at all; in plates 1 and 4 some reduction in the number, though in some cases there may be no observable difference between these plates and the controls.

Each student needs: Five $\frac{3}{4}$-inch test tubes, twelve petri dishes, twelve tubes of agar, four one-c.c. pipettes.

\section{LESSON IX}

\section{TITRATION OF AGGLUTININS BY MACROSCOPIC METHOD}

THE clumping of bacteria by immune serum causes a homogeneous suspension to form flocculi easily visible to the naked eye, which, on standing, settle to the bottom of the tube, making the supernatant fluid clear. The macroscopic test is considered more accurate than the microscopic since one is less often deceived by small clumps of bacteria which may form spontaneously in salt solution or broth for various reasons and are readily visible under the microscope but do not come together in large enough masses to cause a precipitate visible to the naked eye. It is much simpler to carry out a quantitative titration of the agglutinative power of the serum by setting it up in test tubes than by preparing hang-drops of each dilution. Furthermore, since the quantities used in these tests are relatively large, slight inaccuracies in measurement do not lead to such gross errors as would 

similar inaccuracies in the microscopic method. For these reasons the macroscopic method is the one usually employed in experimental investigations. On the other hand, in testing patient's sera against the typhoid bacillus (the Widal reaction) considerable information is given by the cessation of motility of the bacilli in the presence of immune serum. It is desirable to use small amounts of serum and unnecessary to set up more than three or four dilutions in one test.

The macroscopic test may be carried out with living bacteria, with bacteria killed either by exposure to heat $\left(56^{\circ} \mathrm{C}\right.$.) or by exposure to weak antiseptics such as phenol, 1 per cent solution, or formaldehyde 0.8 per cent. Killed suspensions of bacteria may be kept a long time in the ice box and still remain serviceable. The flocculation is most easily observed in narrow test tubes, $\frac{3}{8}$ of an inch in diameter, but larger tubes can also be used without difficulty. Some workers prefer to use tubes pointed at the bottom, similar to the centrifuge tubes, since the sediments which settle out can be readily observed in the tips of these tubes.

The period of incubation varies. A marked reaction is visible after an hour at $37^{\circ}$, but with many organisms it is necessary to incubate for two hours to obtain clear-cut results, and the flocculation often becomes more distinct when the tubes are removed from the water bath and placed in the ice box for from half an hour to 12 hours. Such organisms as the streptococcus ${ }^{1}$ and the staphylococcus usually require the longer periods of incubation, and agglutination is favored by a temperature of $56^{\circ}$. On the other hand, for organisms of the typhoid-colon group long incubation is unnecessary.

Reagents:

1. Serum of a rabbit immunized against typhoid. For this test the serum of animals immunized by the class should be used, the members in charge of the rabbits bleeding them from the carotid at the previous exercises and distributing to each other member of the class 2 c.c. of a 1-10 dilution of the serum.

2. B. typhosus -24 hour culture on agar slant.

3. Normal salt solution.

${ }^{1}$ Streptococcus agglutination requires a special and complicated technique to be satisfactory and then isn't. 



\section{A}

Prepare a suspension of typhoid bacilli by adding 10 c.c. of salt solution to an agar slant culture and gently rubbing the growth from the surface of the agar by means of a platinum loop or a capillary glass pipette, being careful not to cut the surface of the agar. Shake the tube gently without wetting the stopper and allow to stand for 10 minutes so that the larger clumps may settle to the bottom. Take a capillary glass pipette, plug it at the suction end with non-absorbent cotton and provide it with a rubber nipple. Draw off 8 or 9 c.c. of the upper portion of the suspension, being careful not to disturb the sediment and place in a separate test tube, taking care that the suspension does not flow against the upper portions of the tube. Add 0.2 c.c. of 40 per cent formaldehyde and place in water bath at $56^{\circ}$ for thirty minutes. If clumps are still visible the suspension may be filtered through a moist paper.

B

Prepare the following dilutions of the immune serum in test tubes: 1

1. $1-10=$ dilution as distributed

2. $1-50=0.5$ c.c. of $1-10$ dilution +2 c.c. salt solution

3. $1-250=0.5$ c.c. of $1-50$ dilution +2 c.c. salt solution

4. $1-500=1.0$ c.c. of $1-250$ dilution +1 c.c. salt solution

5. $1-1000=1.0$ c.c. of $1-500$ dilution +1 c.c. salt solution

6. $1-2000=1.0$ c.c. of $1-1000$ dilution +1 c.c. salt solution

\section{C}

Place 0.5 c.c. of each dilution of serum (1-10 to 1-2000) in a series of agglutination tubes and in an additional tube 0.5 c.c. of salt solution for control.

To each tube add 0.5 c.c. of the killed typhoid suspension. This, of course, doubles the dilution in each case and the tubes should be labeled 1-20, 1-100, 1-500, etc., up to 1-4000. Shake gently till the two fluids mix. The typhoid suspension should be distributed by means of a pipette carefully plugged at the upper end with non-absorbent cotton. This should be used wherever bacteria are handled with a pipette, even when they are thought to have been killed.

Place the tubes in the water bath, at $37^{\circ} \mathrm{C}$., for one hour, and observe carefully by transmitted light. Record the results and place the tubes in the ice box for one half hour and again make a reading. Read again on the following day.

${ }^{1}$ Instructor should adjust this schedule by a previous titration. 



\begin{tabular}{|c|c|c|c|}
\hline TUBE & Serum & TYPHOID EMULSION & Result \\
\hline $\begin{array}{l}1 \\
2 \\
3 \\
4 \\
5 \\
6 \\
7 \\
8\end{array}$ & $\begin{array}{ccc}1-10 & 0.5 & \text { c.c. } \\
1-50 & 0.5 & \text { c.c. } \\
1-100 & 0.5 & \text { c.c. } \\
1-250 & 0.5 & \text { c.c. } \\
1-500 & 0.5 & \text { c.c. } \\
1-1000 & 0.5 & \text { c.c. } \\
\text { Salt sol. } & 0.5 \text { c.c. } \\
\text { Normal serum } & 1-20 & 0.5 \text { c.c. }\end{array}$ & $\begin{array}{l}0.5 \text { c.c. } \\
0.5 \text { c.c. } \\
0.5 \text { c.c. } \\
0.5 \text { c.c. } \\
0.5 \text { c.c. } \\
0.5 \text { c.c. } \\
0.5 \text { c.c. } \\
0.5 \text { c.c. }\end{array}$ & \\
\hline
\end{tabular}

D

The students in charge of the immune rabbits should test at the same time the samples of serum which were obtained from the rabbits before they received their first injection and which have been stored in the ice box meanwhile. In this case one tube of undiluted serum should be tested, one of a 1-10 dilution, one of 1-50. It is not necessary to test higher dilutions.

\section{MACROSCOPIC METHOD OF PRÖSCHER}

Take four glass saltcellars. In the first place 0.5 c.c. of 1-10 dilution of serum used in the first experiment; in the second 0.5 c.c. of $1-500$ serum; and in the third 0.5 c.c. of 1-2000 dilution; in the fourth 0.5 c.c. of salt solution. To each add 0.5 c.c. of typhoid suspension. The saltcellars are stacked one on top of the other and placed in the incubator for one hour. At the end of this time they are taken out and may be studied under low power of the microscope. A record is made of the amount of clumping in each preparation.

\section{THERMOSTABILITY OF AGGLUTININS}

The agglutinins like the bactericidal sensitizing substance are resistant to moderate heating but they do not require the reactivation by the heat-sensitive alexin which is present in normal serum. They are, however, destroyed by exposure to temperatures of from $70^{\circ}$ to $80^{\circ}$, in which respect they also resemble the sensitizing substance.

In each of three agglutination tubes place 0.5 c.c. of a 1-10 dilution of the immune serum. Place one tube in a water bath at $56^{\circ} \mathrm{C}$. for one half hour. Place a second tube in a water bath at $73^{\circ} \mathrm{C}$. for one half hour. Reserve the third tube as a control. After heating add 0.5 c.c. of 

the killed typhoid suspension to each tube and incubate as in the first experiment. It should be noted that the sensitiveness of the immune bodies to heat varies somewhat according to the dilution in which they are exposed, and if desired, exposure to $56^{\circ} \mathrm{C}$. may be repeated with undiluted serum.

The student is referred to the literature given in the text-book on the work of Joos and others on the variation in heat stability of agglutinins according to whether they are produced by the injection of heated or unheated bacteria.

Each student needs: 2 c.c. typhoid immune serum, 1 typhoid culture on agar slant.

Normal saline, $8 \frac{3}{4}$-inch test tubes, 2 1-c.c. pipettes, $12 \frac{3}{8}$-inch test tubes, 4 salt cellars.

\section{LESSON X \\ AGGLUININS (Continued) \\ I. Agglutination by Microscopic Method \\ (WIDAL TEST)}

Dilutions for the microscopic test may be made in the same manner as those for the macroscopic, but it is often desirable in clinical tests to work with smaller amounts of serum than can be measured accurately in the ordinary graduated pipettes. In this case capillary pipettes are used and the serum is measured either by counting drops of serum and of salt solution, the same pipette held at the same angle being used for both to insure accuracy, or by using as an arbitrary unit the amount of fluid contained in a capillary pipette from the tip to a wax pencil mark placed about an inch from the tip. Students should practice making dilutions by both of these methods. The former is the usual method employed in diagnostic work; the latter, however, is more accurate.

\section{Reagents :}

1. Serum of rabbit immunized to B. typhosus.

2. B. typhosus -24 hour culture in broth.

3. Salt solution.

\section{A}

Take four watch glasses or saltcellars and by means of a capillary pipette provided with a rubber nipple place 9 drops of salt solution in the first watch glass and 5 drops in each of the other three. With the same pipette place one drop of serum in the first saltcellar; (if a highly 

immune animal serum is used this should previously be diluted about 1-100). Mix this dilution of serum thoroughly by drawing it in and out of the pipette several times. Then place 5 drops of this first dilution in the second watch glass. Mix the contents of the second glass as before. Place 5 drops from the second glass in the third glass; return the remainder of the fluid to the second glass, mix the contents of the third watch glass and remove 5 drops of this last to make its volume equal to that of the others. We now have four watch glasses, each containing 5 drops of fluid, representing 1-10, 1-20, 1-40 dilutions of the serum in the first three, and salt solution in the fourth. The pipette is now thoroughly rinsed with salt solution and filled with the typhoid broth. Five drops of the broth are allowed to fall into each of the watch glasses, reducing the dilutions to 1-20, 1-40, and 1-80. These are the usual dilutions used in the Widal test for diagnosis. By means of a platinum loop a series of hang-drop preparations is then made, first with the control, then of the highest dilution, etc. The drops are allowed to stand at room temperature for an hour and are then studied under a high, dry lens of a microscope and the completeness of the clumping and the loss of motility in the different preparations recorded.

\begin{tabular}{c|c|c|c}
\hline \hline Watch Glass No. 1 & Watch Glass No. 2 & Watch Glass No. 3 & W Atch Glass No. 4 \\
\cline { 2 - 3 } & Salt solution & Salt solution & Salt solution \\
9 drops & 5 drops & 5 drops & 5 drops \\
+ & + & + & + \\
Immune serum & Mixture No. 1 & Mixture No. 2 & 0 \\
1 drop & 5 drops & 5 drops & \\
\hline \hline
\end{tabular}

Discard 5 drops of Mixture No. 3 and add 5 drops of a broth culture of B. typhosus to each glass.

A similar test, using the same reagents, measured by the Wright technique, should also be set up :

Take four watch glasses as before and a capillary pipette, broken off, squarely tipped, stoppered with cotton, and provided with a rubber nipple. Place a mark with a wax pencil about one inch from the tip of the pipette. Pour out salt solution into a watch glass or cover of a Petri dish so that it is easily reached with a pipette. Draw up salt solution to the mark, admit a bubble of air, draw up salt solution again to the mark, admit a bubble of air, and proceed until 9 units of salt solution have been taken up. Then take up serum to the mark and discharge the 

entire contents of the pipette into the first watch glass ; mix by drawing the solution in and out of the pipette several times. Take up five units of salt solution into the pipette in similar manner, then five units of the first dilution, and place this mixture in the second watch glass. Place five units of salt solution and five units of the second dilution in the third watch glass. Remove five units from the third watch glass and discard. Place five units of salt solution alone in the fourth glass. Then with this same pipette measure five units of typhoid broth into each of the watch glasses. Prepare hang-drops and incubate and observe as above.

Another method commonly used is to prepare the dilutions of serum in one of the two ways given above, and then place on a series of cover glasses with a platinum loop a drop of typhoid broth, then on each glass with the same loop a drop of diluted serum, after which the two drops are stirred together by means of a capillary pipette sealed at the end. This method offers no advantages over the preceding.

The method sometimes used for clinical diagnosis, of diluting with counted loopfuls of saline drops of dried blood sent to the laboratory on glass slides, is exceeding inaccurate.

\section{EfFect of Salt on Agglutination}

The agglutination of bacteria which occurs in the presence of immune serum has many analogies to the flocculation of colloidal suspensions by electrolytes and is dependent on the presence of electrolytes in the solution. Bacteria sensitized with immunized serum agglutinate in the presence of traces of sodium chloride and other inorganic salts, but not if suspended in distilled water. These salts may also cause unsensitized bacteria to agglutinate, and false clumping due to their action is sometimes observed in the control tubes of agglutination tests, especially if the bacteria are grown in media which have become concentrated by drying. This effect is more easily demonstrated with certain salts of the heavy metals than with sodium chloride. The following experiment will serve to illustrate the effect of electrolytes on the agglutination of sensitized and unsensitized bacteria:

Reagents :

1. Serum of animal immunized to B. typhosus.

2. B. typhosus -24 hour agar slant.

3. Distilled water. 

4. 10 per cent salt solution.

5. Copper sulphate solution 0.8 per cent.

Prepare typhoid suspension (killed with formalin as in previous lesson for the sake of safety). Place in each of two centrifuge tubes, with pointed tip, 2 c.c. of the suspension. To tube A add 2 c.c. of agglutinating serum diluted 1-50. To tube B add 2 c.c. of distilled water. Allow the tubes to stand at $37^{\circ} \mathrm{C}$. for 30 minutes. Centrifugalize the tubes at high speed until the supernatant fluid is clear. Resuspend the sediments in 5 c.c. of distilled water and again centrifugalize. To the washed sediments add 2 c.c. of distilled water and draw the mixture repeatedly in and out of the capillary pipette in order to break up the clumps and obtain an even suspension. Set up the following tests in agglutination tubes :

1. Sediment A 0.5 c.c. Distilled water 0.5 c.c.

2. Sediment A 0.5 c.c. $10 \%$ salt sol. 0.09 c.c. Dist. water 0.4 c.c.

3. Sediment A 0.5 c.c. Copper sulphate sol. $0.8 \%$

Distilled water

4. Sediment B 0.5 c.c. 0.02 c.c. 0.5 c.c. 0.02 c.c.

0.5 c.c.

5. Sediment B 0.5 c.c. 0.1 c.c.

0.5 c.c.

6. Sediment B 0.5 c.c.

0.5 c.c.

The tubes are placed in the water bath at $37^{\circ}$ for one hour and then observed. Tubes 2, 3 and 5 should show agglutination.

This experiment shows that electrolytes are necessary for the appearance of agglutination and that bacteria even though they may have united with the specific serum agglutinins do not clump in the absence of such salts. It is the mainstay of Bordet's view of agglutination as a "two-phase" reaction in which one step is the union with agglutinins, the other the actual clumping brought about by the salts.

Each student needs: 8 watch glasses, 2 centrifuge tubes, $6 \frac{3}{8}$-inch test tubes, glass tubing, test tube rack.

Bacillus typhosus, 24-hr broth culture, 24-hr. agar slant.

\section{LESSON XI}

\section{ABSORPTION OF BACTERIAL AGGLUTININS}

THE serum of an animal immunized simultaneously with two species of bacteria develops agglutinative power for each of these species. The agglutinins for the two species may be shown to be distinct by treating the serum with a heavy emulsion of one of 

them, and subsequently removing the agglutinated bacteria by centrifugation. The agglutinins for this species having been absorbed by the bacteria will be removed by this procedure, leaving the agglutinins for the species not used in the absorption uninfluenced. For the complete removal of agglutinins it is necessary to leave the serum in contact with the bacteria for a long period and often to repeat the treatment of the serum with bacterial suspension several times. These facts are illustrated in Experiment 1.

The experiment illustrates the general principle that an animal may produce specific and distinct antibodies simultaneously against a number of different antigens.

\section{Experiment 1}

Absorption of Agglutinins from the Serum of an Animal ImMUNIZEd Against Two Species of Bacteria

Reagents :

1. Serum of an animal simultaneously immunized against Bacillus typhosus and Bacillus coli. The students who have immunized this animal should bleed it from the carotid at a preceding lesson and should distribute the serum to other members of the class, diluted 1-10 with salt solution. Each student requires 5 c.c. of this dilution.

2. Thick suspension of typhoid bacilli killed by heating one hour at $55^{\circ} \mathrm{C}$. $60^{\circ} \mathrm{C}$.

3. Thick suspension of colon bacilli killed by heating one hour at

Both these suspensions should be used undiluted for the absorption, and in a dilution of 1-10 for titrating the agglutination.

4. Salt solution.

\section{A. PReliminary titration of agglutinative power of immune SERUM}

The dilutions of serum required for this test should be prepared in $\frac{5}{8}$-inch test tubes according to a protocol to be made out by the individual student. Before making any such series of dilutions it is highly important to write out plainly the amount of serum and salt solution to be placed in each tube in order to avoid errors. 

Set up the following experiment in agglutination tubes :

\begin{tabular}{|c|c|c|}
\hline No. 1 Serum $(1-2$ & 0.5 c.c. + Typ & \\
\hline 2 Serum $(1-100)$ & 0.5 c.c. + Typhoid suspension & \\
\hline 3 Serum $(1-500)$ & 0.5 c.c. + Typhoid suspension & \\
\hline 4 Serum $(1-2000)$ & 0.5 c.c. + Typhoid suspension & \\
\hline 5 Salt solution & 0.5 c.c. + Typhoid suspension & \\
\hline 6 Serum $(1-20)$ & 0.5 c.c. + Colon suspension & \\
\hline 7 Serum $(1-100)$ & 0.5 c.c. + Colon suspension & \\
\hline 8 Serum $(1-500)$ & 0.5 c.c. + Colon suspension & \\
\hline 9 Serum (1-2000) & 0.5 c.c. + Colon suspension & \\
\hline 10 Salt solution & 0.5 c.c. + Colon suspension & \\
\hline
\end{tabular}

Incubate one hour at $37^{\circ} \mathrm{C}$. and record the results.

\section{B. ABSORPTION}

Place in small centrifuge tubes:

A. Serum (1-10) 1.5 c.c. + Thick typhoid suspension 1.5 c.c.

B. Serum (1-10) 1.5 c.c. + Thick colon suspension 1.5 c.c.

Incubate one hour. (For complete absorption, incubation in the thermostat should be followed by 12 or more hours in the refrigerator.) Centrifugalize at high speed and remove the clear supernatant fluid. ${ }^{1}$

\section{TItration OF THE SERUM AFTER ABSORPtion}

The supernatant fluid obtained by centrifugation should be tested undiluted (it corresponds to a 1-20 dilution of the original serum) against the same organism used for absorption, and as the absorption is often incomplete after this short incubation a similar test should be set up of the supernatant fluid diluted 1-5 (corresponding to a 1-100 dilution of the original serum). The supernatant fluid should also be tested against the organism not used in absorption in the highest dilution in which agglutination was found in the preliminary titration.

1. Supernatant fluid A

2. Supernatant fluid A (1-5)

3. Supernatant fluid A

4. Supernatant fluid in highest dilution in which it agglutinated colon in preliminary titration
0.5 c.c. + Typhoid suspension 0.5 c.c. 0.5 c.c. + Typhoid suspension 0.5 c.c. 0.5 c.c. + Colon suspension 0.5 c.c.

1 It should be noted that absolutely complete removal of agglutinins is not possible except by many times repeated absorption. 

5. Supernatant fluid B

0.5 c.c. + Colon suspension

0.5 c.c.

6. Supernatant fluid B (1-5)

0.5 c.c. + Colon suspension

0.5 c.c.

7. Supernatant fluid B

8. Supernatant fluid in highest dilution in which it agglutinated typhoid in original titration

9. Salt solution

0.5 c.c. + Typhoid suspension 0.5 c.c.

10. Salt solution

0.5 c.c. + Typhoid suspension 0.5 c.c. 0.5 c.c. + Typhoid suspension 0.5 c.c. 0.5 c.c. + Colon suspension 0.5 c.c.

Incubate one hour at $37^{\circ} \mathrm{C}$. and record results.

Tubes 1, 2, 5 and 6 should show no agglutination if absorption has been complete. If all the agglutinin has not been absorbed, however, there may be clumping in tubes 1 and 5 . The bacteria in tubes $3,4,7$ and 8 should be agglutinated.

\section{GROUP AGGLUTININS}

The serum of animals highly immunized to one species of bacteria will often agglutinate closely related bacteria, though this action is invariably weaker than the agglutinative power for the bacteria used in immunizing the animal.

Thus the serum of an animal which before treatment agglutinated Bacillus coli in dilutions of 1-20 and Bacillus typhosus in dilutions of 1-5, after immunization with Bacillus typhosus may agglutinate Bacillus coli as highly as 1-100, and Bacillus typhosus up to $1-10,000$ or more. This indicates a close similarity in the chemical constituents of the two antigens - the Bacillus typhosus antigen containing small amounts of the protein present in Bacillus coli. Absorption with Bacillus typhosus will remove both the Bacillus typhosus and the colon agglutinins. Absorption with Bacillus coli will take out only the colon agglutinin, the serum still agglutinating Bacillus typhosus 1-10,000.

The serum here contains at least two types of agglutinins, the so-called major or specific agglutinin which reacts only with the homologous bacteria, and the minor or group agglutinins which react both with the homologous bacteria and with the allied species. If such a serum is added to a suspension of the homologous bacteria both major and minor agglutinins are absorbed 

and the supernatant fluid obtained after centrifugation has lost its agglutinative power both for the homologous strains and for allied species. If, on the other hand, the serum is treated with a suspension of the one allied species, the minor agglutinins only are absorbed. The supernatant fluid then shows undiminished agglutinative power for the homologous strain, but does not agglutinate the allied strain used in absorption. These facts are brought out in Experiment 2.

\section{Experiment 2}

Absorption of Major and Minor Agglutinins from Serum of an Animal Immunized Against a Single Species

Reagents :

1. Serum of an animal immunized to Bacillus typhosus. The serum must be known to contain group agglutinins for Bacillus coli.1

2. Two specimens of the same serum in 1-20 dilution which have stood in contact over night with typhoid and with colon bacilli respectively. These may be prepared on the previous day by the instructor. Heavy suspensions of typhoid and colon bacilli are first prepared by washing off the growth of a number of agar bottles and heating for one hour at $56^{\circ}$ and $60^{\circ}$ respectively. To each of these suspensions is added an equal volume of a 1-10 dilution of agglutinating serum. The tubes are incubated for one hour at $37^{\circ}$, shaken thoroughly and placed in the ice box over night. They should be shaken once or twice during the period of 24 hours. They are then centrifugalized and the supernatant fluids removed and used in the second part of the experiment.

3. Suspension of killed typhoid bacilli as in Experiment 1.

4. Suspension of killed colon bacilli as in Experiment 1.

5. Salt solution.

(1) Titrate the original antityphoid serum against both typhoid and colon emulsions according to the following protocol. This gives a basis for comparison with a similar test on the same serum after it has been in contact with the bacteria.

1 To insure successful class work this must be previously ascertained in each case, since individual animals may vary considerably in regard to the production of minor agglutinins. 

1. Serum (1-10) 0.5 c.c. + Typhoid suspension 0.5 c.c.

2. Serum (1-10) 0.5 c.c. + Colon suspension 0.5 c.c.

3. Serum (1-50) 0.5 c.c. + Typhoid suspension 0.5 c.c.

4. Serum (1-50) 0.5 c.c. + Colon suspension 0.5 c.c.

5. Serum (1-200) 0.5 c.c. + Typhoid suspension 0.5 c.c.

6. Serum (1-200) 0.5 c.c. + Colon suspension 0.5 c.c.

7. Serum (1-1000) 0.5 c.c. + Typhoid suspension 0.5 c.c.

8. Serum (1-4000) 0.5 c.c. + Typhoid suspension 0.5 c.c.

9. Salt solution 0.5 c.c. + Typhoid suspension 0.5 c.c.

10. Salt solution 0.5 c.c. + Colon suspension 0.5 c.c.

Incubate one hour at $37^{\circ} \mathrm{C}$. and observe.

(2) Set up the following tests with the same serum, from which in this case, however, the agglutinins have been removed by absorption :

1. Serum absorbed with typhoid 0.5 c.c. + Typhoid suspension 0.5 c.c.

2. Serum absorbed with typhoid 0.5 c.c. + Colon suspension 0.5 c.c.

3. Serum absorbed with colon 0.5 c.c. + Typhoid suspension 0.5 c.c.

4. Serum absorbed with colon 0.5 c.c. + Colon suspension 0.5 c.c.

5. Serum absorbed with colon

in the highest dilution

which agglutinated

typhoid bacilli before absorption

0.5 c.c. + Typhoid suspension 0.5 c.c.

Incubate for one hour and observe.

Each student needs:

$25 \frac{3}{4}$-inch test tubes, 8 1-c.c. pipettes, test tube rack, $35 \frac{1}{2}$-inch test tubes, 4 centrifuge tubes, test tube racks.

\section{LESSON XII}

\section{EFFECT OF HAMOLYTIC AND HAMAGGLUTINATIVE SERA IN VIVO}

\section{Preliminary Tests}

A RABBIT receives at four-day intervals four intravenous injections of 2 c.c. of washed, cat's red blood cells. For obtaining the cells a cat under ether is bled from the carotid or jugular. The defibrinated cat's blood if sterile can be kept four days and thus used for two injections. Seven to ten days after the last injection the rabbit is bled and the hremolytic and agglutinative power of the inactivated immune serum for cat's cells is tested. 

The following test is made to determine the hæmolytic power of the anti-cat rabbit serum :

\begin{tabular}{|c|c|c|c|c|}
\hline TUBE & ImMUNe Serum & $\begin{array}{c}\text { GUINEA PIG SERUM } \\
\text { OR CAT'S SERUM, } \\
\text { FREAH DILUTED } \\
1-10\end{array}$ & SALINE UP TO & $\begin{array}{l}5 \% \text { WASHED CAT's } \\
\text { RED BLOOD CELLS }\end{array}$ \\
\hline $\begin{array}{l}1 \\
2 \\
3 \\
4 \\
5 \\
6\end{array}$ & $\begin{array}{lll}\text { Diluted } 1-10 & 0.5 \\
\text { Diluted } & 1-10 & 0.1 \\
\text { Diluted } 1-100 & 0.5 \\
\text { Diluted } 1-100 & 0.1 \\
\text { Diluted } 1-400 & 0.2 \\
\text { Diluted } 1-400 & 0.1\end{array}$ & $\begin{array}{l}0.5 \text { c.c. } \\
0.5 \text { c.c. } \\
0.5 \text { c.c. } \\
0.5 \text { c.c. } \\
0.5 \text { c.c. } \\
0.5 \text { c.c. }\end{array}$ & $\begin{array}{l}2 \text { c.c. } \\
2 \text { c.c. } \\
2 \text { c.c. } \\
2 \text { c.c. } \\
2 \text { c.c. } \\
2 \text { c.c. }\end{array}$ & $\begin{array}{l}0.5 \text { c.c. } \\
0.5 \text { c.c. } \\
0.5 \text { c.c. } \\
0.5 \text { c.c. } \\
0.5 \text { c.c. } \\
0.5 \text { c.c. }\end{array}$ \\
\hline
\end{tabular}

In testing the agglutinative power set up a similar series but without fresh serum.

\section{In Vivo Effect of Hamolytic Serum}

Etherize two cats and inject 1 c.c. of immune serum into one and 3 c.c. into the other. Give the injections directly into the saphenous vein with a fine hypodermic needle. Put the first cat into a clean cage with a drain for the collection of urine after 6, 24 and 48 hours. (The first urine will contain large amounts of hæmoglobin, the last bile.) Half an hour after the injection collect a specimen of the cat's serum by pricking the ear vein. Centrifugalize and observe the blood-tinged serum. Make smears of the blood, stain, and note with oil immersion lens the phagocyted red cells in some of the leucocytes. The second cat will probably die at once. If so, autopsy immediately and look for clumps of agglutinated red cells in portal and pulmonary veins.

To demonstrate the in vivo effect of complement, give a rabbit an intravenous injection of 2.0 c.c. of $25 \%$ suspension of sensitized sheep blood cells. (In sensitizing the cells, regard 0.1 c.c. of $25 \%$ cells as a unit and add two units of amboceptor for every unit of cells. After the cells have stood in contact with the amboceptor for one half hour, centrifugalize them and make them up to the original volume of $25 \%$ suspension).

After a half hour collect a specimen of serum from the rabbits' ear and examine for dissolved hæmoglobin. Make a smear of the blood and examine for phagocytosis. Examine the rabbit's urine after 6, 24 and 48 hours.

The experiments in this lesson need not be done by the entire class but can be done as a demonstration by a small group of students working with the instructor. 

Materials:

5 Cats

2 Rabbits

Hypodermic syringe

Fresh guinea pig serum

Test tubes

$4 \frac{3}{4}$-inch test tubes

$6 \frac{1}{2}$-inch test tubes

Test tube racks

Cover slips, microscope slides

Blood stain (Wright's, Giemsa's or Jenner's)

1 Centrifuge tube

\section{LESSON XIII}

\section{ISOHAMOLYSIS AND ISOAGGLUTINATION}

\section{Transfusion Tests}

ANTIBODIEs in the blood of one animal capable of acting on the blood of another animal of the same species are called isoantibodies. Isoagglutinins and isohæmolysins sometimes occur naturally and they can often be made to appear by immunization of animals with the blood of other animals of the same species. They appear with a peculiar regularity which indicates that there are certain groups of individuals within one and the same species whose blood is strictly homologous only with other members of the same group. Among human beings there are four such groups, sharply defined, permanent and hereditary. The existence of these antibodies is of practical importance in connection with blood transfusion because more or less serious results may ensue if a patient is transfused with the blood of a donor who belongs to another group and whose blood is therefore either hæmolytic or hæmagglutinating for the patient, or vice versa. (See table in "Infection and Resistance," page 238.)

Before transfusion, therefore, unless the urgency of the case forbids, a number of prospective donors are tested, and one is chosen whose blood does not lake or agglutinate when mixed with that of the patient. The serum of each donor must be tested with the blood cells of the patient and the serum of the patient with the cells of each donor.

There are two methods of collecting blood for these tests: 

(A) When possible from a vein, 3 to 5 c.c. in a test tube for serum, 10 drops in 5 c.c. of a solution containing 1 per cent sodium citrate and 0.9 per cent sodium chloride, for the red cell emulsion. $(B)$ By pricking the finger with a Hagedorn needle and milking out from 1 to 2 c.c. of blood which is collected in a Wright capsule for serum and 10 drops in citrate-salt solution for cells.

Students make Wright capsules and collect specimens of blood from each other. The capsules are of heavy glass tubing, 7 to $8 \mathrm{~mm}$. in diameter, about $10 \mathrm{~cm}$. long, and drawn to a capillary opening of about $1 \mathrm{~mm}$. diameter at each end. They are laid on the table and drops of blood expressed from the finger are allowed to enter them by capillary action. When the capsule is two thirds full, the blood is allowed to clot and the open end of the capsule is sealed in the flame, great care being taken not to heat the blood. Serum is obtained by centrifugalizing the capsules and cutting them with a small file.

The cell emulsions are prepared by washing the citrated blood twice with salt solution and making up to 5 per cent by comparing the opacity with that of a 5 per cent sheep cell suspension, or by measuring with capillary pipette 1 volume of sedimented human cells and 19 volumes of saline. ${ }^{1}$

Each student should make 12 Wright capillary pipettes of strong glass tubing, 4 to $5 \mathrm{~mm}$. in diameter. These pipettes are made by cutting the tubing into pieces about $10 \mathrm{~cm}$. inches long, heating the center of each piece to melting and drawing out to a capillary of about $1 \mathrm{~mm}$. diameter and 10-12 cm. inches long. The capillary is then broken at the middle, giving two pipettes. Adjust nipple to the pipettes. Make a mark on the capillary end of each pipette near the hilt. Draw up 1 volume of serum to the mark, then a small buble of air, then another volume of serum, and another bubble of air, and then a volume of the cells which are to be mixed with the serum; (the serum is used in excess because in this way it is sometimes possible to detect a weak hæmolytic action which would otherwise be overlooked on account of the low complement activity of human blood). Draw the mixture into the body of the pipette and seal the capillary tip in the flame. Mix the fluid by rotating the pipette. Remove the nipple. Throughout these steps keep the pipette approximately horizontal so that the fluid remains in the body of it and does not flow to either end. Seal the open end of the pipette by dipping in melted paraffine. Mark the pipette with a glass pencil, using the number assigned to the serum as the numerator, that assigned to the cells as the denominator, of a fraction.

${ }^{1}$ It is not necessary in practical work to wash the cells. Three or four drops of blood in citrate salt solution furnishes satisfactory material. 

Each student tests one specimen of serum against 10 different individuals' red cells. Make a control of each serum with its own red cells. Lay all the pipettes on their sides on a tray and incubate at $37.5^{\circ} \mathrm{C}$. for one hour. Then make observations for hæmolysis or agglutination and make the results of all the tests into a table to illustrate Landsteiner's law of the groupings of human isoagglutination.

By the original classification of blood groups the groupings may be arranged as follows on the assumption that there are two distinct agglutinins and corresponding agglutinogens:

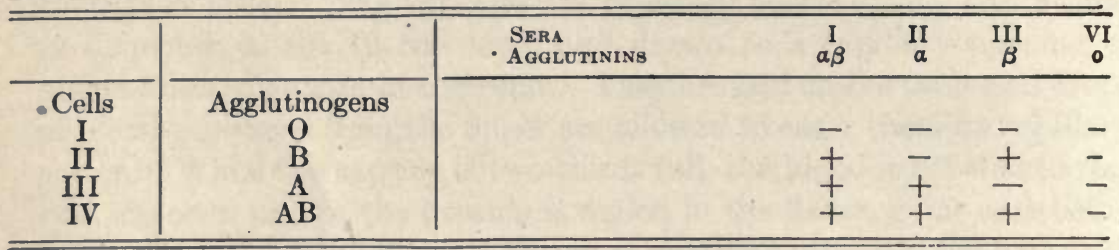

From this table the student can determine the grouping of his tests. It will be noted that any individual can be grouped by testing his cells against sera of groups II and III. Study this out on the table above. Every serologist should know his own group.

The students should carry out a few simplified tests by mixing a drop of blood suspension and a drop of serum on a slide. The slide method is sufficient for all practical purposes.

The class needs:

Heavy glass tubing 7-8 $\mathrm{mm}$. diameter.

Heavy glass tubing 4-5 $\mathrm{mm}$. diameter.

Litre 1 per cent sodium citrate in 0.6 per cent sodium chloride.

Litre 0.9 per cent sodium chloride solution.

Triangular files.

Rubber nipples to fit $5 \mathrm{~mm}$. tubing (one nipple for each student). Hard paraffine in casserole. 



\section{LESSON XIV}

\section{TITRATION OF PRECIPITATING SERA FROM RABBITS}

\section{Specificity of Precipitins}

Precipitating sera are active against proteins in high dilutions. Their specificity is great but is limited by group reactions so that a precipitating serum for the protein of any species of animal or bacteria will give precipitation. with closely related species in low but not in high dilutions. On this is based Nuttall's well-known study of blood relationships.

Students working in groups bleed serum-treated råbbits (Lesson I) from the carotid 10 days after the last injection, taking about 20 c.c. of blood in small centrifuge tubes. The animal should be in a fasting state in order that the serum will be clear. Allow the blood to clot and centrifugalize.

\section{Experiment 1}

One half of the students in the class make dilutions in large test tubes of sheep serum or human serum respectively (according to particular serum with which rabbit has been treated) as follows: 1-10, 1-20, $1-50,1-100,1-200,1-500,1-1000$. In order to test the specificity of the reaction the other half of the students make similar dilutions of serum from other species of animal - guinea pig, dog, cat, sheep, horse, as available.

Then set up the following mixtures in small "precipitation" tubes (tubes of about 5-8 $\mathrm{mm}$. diameter):

\begin{tabular}{c|c|cc}
\hline \hline Tube & Immune Rabit Serum & \multicolumn{2}{|c}{ Antigen (Precipitinogen) } \\
\cline { 2 - 3 } 1 & 0.1 c.c. & Undiluted & 0.1 c.c. \\
2 & 0.1 c.c. & $1-20$ & 0.1 c.c. \\
3 & 0.1 c.c. & $1-50$ & 0.1 c.c. \\
4 & 0.1 c.c. & $1-100$ & 0.1 c.c. \\
5 & 0.1 c.c. & $1-200$ & 0.1 c.c. \\
6 & 0.1 c.c. & $1-500$ & 0.1 c.c. \\
7 & 0.1 c.c. & $1-1000$ & 0.1 c.c. \\
8 & 0.1 c.c. & Salt solution & 0.1 c.c. \\
9 & Salt solution 0.25 c.c. & Undiluted antigen 0.1 c.c. \\
\hline \hline
\end{tabular}

In making these mixtures, put the anti-serum into the tubes first and then run the dilution into the tubes with a nipple pipette in such a way that the latter is layered over the former as in a Heller's test for albumin in urine. This is the so-called "ring test." . The precipitum shows as a white line at the contact of the two fluids. After this ring 

has formed, the tubes can be shaken up and the ordinary precipitin reaction (i.e., turbidity and flocculation) can be observed. Note the results after one half hour and one hour at $37^{\circ} \mathrm{C}$. and again after 12 hours in the ice box. Is there a "pro zone"? -

\section{Experiment 2}

\section{Effect of Heat on Precipitins}

Heat slowly inactivates precipitins. They cannot be reactivated by fresh serum (alexin, complement), in this regard differing from hæmolysins and bactericidal antibodies.

Heat 0.5 c.c. of precipitin serum for two hours at $60^{\circ} \mathrm{C}$. Mix 0.1 c.c. of the heated serum with 0.1 c.c. of that dilution of the antigen which was found in Experiment 1 to give the optimum precipitation.

Mix 0.1 c.c. of the heated serum with 0.1 c.c. of fresh normal rabbit serum and test this mixture also with the optimum dilution of antigen. Make observations.after 1 hour at $37^{\circ} \mathrm{C}$. and again after 12 hours in ice box.

For each student:

2 c.c. Immune serum (rabbit whose preparation was begun in Lesson I).

1 c.c. Antigen serum (human, sheep or horse serum for half the Salt solution. class, other animals' sera for the other half).

12 Precipitation tubes. Test tube rack. Nipple pipette.

6 one-c.c. graduated pipettes.

0.1 c.c. normal rabbit serum, fresh,

$8 \frac{3}{4}$-inch test tubes.

Precipitins can also be produced against proteins heated to $70^{\circ}$ or over. For the principles of such experiments see Infection and Resistance, page 260. 



\section{LESSON XV}

\section{FORENSIC PRECIPITIN TEST}

THE precipitin reaction is used in medicolegal work to identify blood stains and to detect adulterations or substitutions in meat or other food products. Since the specificity of the precipitin reaction is subject to limitations similar (though not as marked) to those discussed in the case of agglutination, the precipitating serum used in forensic tests must be very potent. Preliminary test should show that the serum gives distinct clouding with its homologous antigen diluted 1 to 1000 , within five or ten minutes at room temperature.

An effort is made to get the suspected protein into approximately this dilution.

Each student gets :

2.0 c.c. antihuman serum.

2.0 c.c. antisheep serum.

0.4 c.c. normal rabbit serum.

Two specimens of material with dry blood to be identified. (To some of the students sheep blood is given; to others human blood or that of other species.)

From each of the specimens upon which blood has been dried the blood must be soaked off in salt solution. This can be done by placing the material in a test tube with $\mathbf{5}$ c.c. salt solution and shaking for 10 or 15 minutes until the solution presents a lasting foam. This is evidence that the protein is in solution in a concentration of at least 1 part in 1000. Old specimens must often be left in salt solution in the refrigerator for $\mathbf{2 4}$ hours or longer. Such prolonged soaking is done in the refrigerator in order to avoid destruction of the antigen by bacterial growth. Since the nature of the reaction makes it necessary that the material to be examined shall be absolutely clear, it is now cleared by filtration or centrifugation; if there is enough material the acetic-acidand-boiling test can be done and the cloud compared in heaviness with a 1-1000 dilution of serum of the suspected variety of blood, similarly 

treated. This gives a rough estimate of the concentration of the antigen. If the solution seems much too concentrated, dilute it until it approaches 1-1000, - i.e. the limit of its still presenting a lasting foam on shaking.

Place the antiserum in the tube first and make a ring test. To do this run antigen very carefully into tube with a nipple pipette so that the two fluids may not be mixed. Watch for a white ring at the line of junction. Be careful to compare this with the control, since a slight opalescence is often seen at the line of junction of salt solution and serum not due to precipitation.

2

1. Unknown solution (a)

2. Unknown solution $(a)$

0.5 c.c. + antihuman serum 0.2 c.c. 0.5 c.c. + normal rabbit

3. Unknown solution (b) serum 0.2 c.c.

4. Unknown solution (b)

0.5 c.c. + antihuman serum 0.2 c.c. 0.5 c.c. + normal rabbit

serum 0.2 c.c.

5. Known human serum (1-1000) 0.5 c.c. + antihuman serum 0.2 c.c.

6. Salt solution

0.5 c.c. + antihuman serum 0.2 c.c.

Observe the tubes for $\mathbf{1 5}$ or 20 minutes at room temperature. Then incubate and observe. After 30 minutes shake up and observe for cloudiness and flocculation.

3

Set up a similar series with antisheep instead of antihuman serum. Let each student report whether either of the specimens he received is sheep or human.

In order that conclusions may be definitely drawn from such a test it is necessary that the tubes containing the unknown solution (say it is suspected of being human blood) and the known human blood, 1-1000 control, should show a definite reaction within not longer than $10 \mathrm{~min}$ utes at room temperature. Antisera too weak to show such a sharp reaction with controls of the known protein are not suitable for such tests.

Each student needs:

$6 \frac{3}{4}$-inch test tubes. 12 Precipitation tubes $6 \mathrm{~mm}$. in diameter. Capillary pipettes.

\section{LESSON XVI}

\section{BORDET-GENGOU PHENOMENON-COMPLEMENT FIXATION}

THe Bordet-Gengou phenomenon is the prototype of all complement fixation methods. It depends on the fact that antigens 

(bacterial and others) in the presence of their specific antisera will fix complement so that the subsequently added red cells sensitized by their appropriate hæmolytic immune-body will fail to be laked, because no free complement is available. Neither the antigen alone nor the antibody alone will fix complement in this manner.

Unfortunately bacterial cell bodies (like many other substances) if in sufficiently large amounts will of their own accord, probably for purely physical reasons, absorb complement, in a non-specific way, i.e., without the presence of a specific antibody.

The immune sera likewise have often the power of absorbing complement in a non-specific way in the absence of antigen and this power must be determined by preliminary titration in order that allowance may be made for it in the main test.

For this reason before doing a Bordet-Gengou reaction (and, as will be seen later, in all complement fixation work) it is necessary to determine the degree to which such non-specific complement fixation will take place with the given antigen and to use in the actual test an amount too small to give such a false reaction.

\section{Experiment 1}

Preliminary Determination of the Non-specific Binding Power of the Bacterial Antigen

Emulsify a 24 hour slant of typhoid bacilli in 10 c.c. of saline solution. Heat at $56^{\circ} \mathrm{C}$ for 30 minutes.

\begin{tabular}{|c|c|c|}
\hline TUBE & BACterial Emelsion & Complement \\
\hline $\begin{array}{l}1 \\
2 \\
3 \\
\\
4 \\
5 \\
6\end{array}$ & $\begin{array}{c}0.4 \text { c.c. } \\
0.2 \\
0.1 \\
1 / 10 \text { dilution of above } \\
0.8 \\
0.5 \\
0.2\end{array}$ & $\begin{array}{c}2 \text { units } \\
6 \\
\text { "6 } \\
\text { " }\end{array}$ \\
\hline
\end{tabular}

${ }^{1}$ Determined by preliminary titration

Add sufficient saline solution to each tube so that the final volume after adding red cells and amboceptor shall equal 2.5 c.c. Incubate one hour in water bath. Add 0.5 c.c. of $5 \%$ red cell suspension plus two units of amboceptor to each tube. Incubate for one half hour in water bath. 



\section{Experiment 2}

Preliminary Determination of the Non-specific Binding Power of the IMmune Serum

\begin{tabular}{c|c|c}
\hline \hline Tube & 1/0 Dilution of Serum 1 & Complement \\
\cline { 2 - 3 } 1 & 0.5 c.c. & 2 units \\
2 & 0.3 & " \\
3 & 0.2 & " \\
4 & 0.1 & \\
\hline \hline
\end{tabular}

${ }^{1}$ Serum from rabbit immunized to typhoid bacilli. This serum should be heated to $55^{\circ}$ for 30 minutes on day of using.

Follow same procedure as directed under Experiment 1.

\section{Experiment 3}

Use that amount of typhoid suspension which is next below the amount which was found to not interfere at all with the hæmolytic action of the complement. Also take that amount of serum which lies next below the amount which did not interfere with hæmolysis. Let us say there was full hæmolysis in Tube 3 of the first set and 2 of the second; we set up the third as follows:

\begin{tabular}{|c|c|c|c|}
\hline TUbE & $\begin{array}{l}\text { BACTERIAL SUSPENBION } \\
1 / 10 \text { DILUTTON }\end{array}$ & $\begin{array}{c}\text { SERUM } \\
1 / 10 \text { Dilution }\end{array}$ & COMPLEMENT \\
\hline $\begin{array}{l}1 \\
2 \\
3\end{array}$ & $\begin{array}{l}0.8 \text { c.c. } \\
0.8 \\
\end{array}$ & $\begin{array}{l}0.2 \text { c.c. } \\
0.2 \text { c.c. }\end{array}$ & $\begin{array}{l}2 \text { units } \\
2 \\
2\end{array}$ \\
\hline
\end{tabular}

Add sufficient saline solution to bring the final total up to 2.5 c.c. and incubate 1 hour in water bath. Add 0.5 c.c. of $5 \%$ red cell suspension and two units of amboceptor to each tube and incubate 30 minutes.

Tubes 2 and 3 are necessary control tests in all complement fixation work, to prove that under the precise conditions under which complement is fixed in Tube 1 it is not fixed by antigen alone or by antiserum alone.

\section{Materials for each student:}

13 half-inch test tubes. Test tube rack.

4 large test tubes.

24 hour typhoid culture.

Platinum loop.

6 one-c.c. pipettes.

1.5 c.c. immune antityphoid serum (diluted).

7. c.c. 5 per cent sheep cell emulsion.

4.0 c.c. 10 per cent guinea-pig serum.

30 units amboceptor.

Salt solution. 



\section{LESSON XVII}

\section{ALEXIN FIXATION BY DISSOLVED PROTEINS AS ANTIGENS (AND BY SPECIFIC PRECIPITATES)}

THE phenomenon of fixation of alexin by the union of antiserum and antigens is not limited to cellular antigens, but occurs whenever a serum containing antibodies is mixed with its corresponding protein antigen in the presence of alexin, or when alexin is treated with the precipitate so obtained. The binding of complement does not, however, depend on the formation of a precipitate, for it occurs in dilutions at which a precipitate no longer can be seen. 

Complement fixation is even more delicate a method of identifying a protein than is the precipitin reaction.

\section{Reagents :}

1. Serum of rabbit immunized against human serum, diluted 1-5.1

2. Human serum, diluted 1-5.

3. Guinea pig serum, diluted 1-10.

4. Washed sheep cells, $5 \%$ suspension.

5. Serum of rabbit immunized against sheep cells (antisheep-cell amboceptor).

Set up the following tubes:

\begin{tabular}{|c|c|c|c|c|}
\hline TUBE & Antihuman Serum 1-5 & Human Serum $1-5$ & $\mid \begin{array}{c}\text { DOG, CAT, HORSE OR } \\
\text { SHEEP SERUM 1-5 }\end{array}$ & $\begin{array}{l}\text { GUINEA-P1G } \\
\text { SERUM 1-10 }\end{array}$ \\
\hline $\begin{array}{l}1 \\
2 \\
3 \\
4 \\
5 \\
6 \\
7\end{array}$ & $\begin{array}{c}0.5 \text { c.c. } \\
0.5 \text { c.c. } \\
0.5 \text { c.c. } \\
0.5 \text { c.c. } \\
0.5 \text { c.c. } \\
-\overline{\text { Tabit serum }} \\
0.5 \text { c.c. }\end{array}$ & $\begin{array}{l}0.25 \text { c.c. } \\
0.025^{2} \\
0.005^{2} \\
- \\
0.25 \text { c.c. } \\
0.25 \text { c.c. }\end{array}$ & $\begin{array}{l}\text { Z } \\
0.25 \text { c.c. } \\
\text { - } \\
\text { - }\end{array}$ & $\begin{array}{l}0.5 \text { c.c. } \\
0.5 \text { c.c. } \\
0.5 \text { c.c. } \\
0.5 \text { c.c. } \\
0.5 \text { c.c. } \\
0.5 \text { c.c. } \\
0.5 \text { c.c. }\end{array}$ \\
\hline
\end{tabular}

Bring all volumes to 2 c.c.

Incubate mixtures one hour at $37^{\circ} \mathrm{C}$.

Sensitize sheep cells by adding two units of antisheep-cell serum to aach 0.5 c.c. of cells.

At the end of the hour add a dose of these sensitized cells to each tube. (The dose is 0.5 c.c. of 5 per cent cells + the proportionate volume of amboceptor.)

Incubate until hæmolysis is complete in control tubes 4,5 and 6.

Tube 4 is inserted as a control test to show that fixation is not given with serum in general but only with human serum. Different students use the sera of different animals as control. If monkey serum is available, let some of the students set up control tests with it.

Compare the dilution of human serum which still gives a positive reaction with the titer which gave a precipitin reaction with the same antiserum in Lesson VII.

1 Where dilutions are made to economize material they must not be taken to have any significance of principle.

2 (Make a preliminary dilution of $1-20$ and add 0.5 c.c. and 0.1 c.c.) 

Each student needs:

\section{Materials}

3.0 c.c. Antihuman serum (1-5).

1.0 c.c. Human serum (1-5).

4.0 c.c. Guinea pig serum (1-10).

4.0 c.c. Sheep cells $(1-20)$.

0.5 c.c. Dog, cat, horse or sheep serum (1-5).

15 units antisheep-cell amboceptor.

Salt solution.

10 one-c.c. pipettes.

15 half-inch test tubes.

1 test tube rack.

$7 \frac{1}{2}$-inch test tubes

$3 \frac{3}{4}$-inch test tubes

6 1-u pipettes.

\section{LESSON XVIII}

\section{FORENSIC COMPLEMENT FIXATION}

THE fixation of complement by the specific action of a protein and the serum of an animal immunized against it, is the basis of a forensic test for the identification of blood stains and also for the recognition of meats placed upon the market (for instance, the detection of horse meat in sausages).

Since the injection of the protein from any organ or tissue of an animal results in antibodies which react with extracts from any other tissue of the identical species (i.e., antibodies which are race-specific and only to a slight degree organ-specific), it is not necessary to produce the antiserum for the detection of meat by injection of meat extract. The injection of serum or of blood of the same species gives quite as useful antibodies and is much more convenient.

For the preparation of extracts from meat Seiffert recommends the infusion of 30 grams of finely chopped meat in 30 c.c. salt solution; the mixture is to stand for 12 hours in the cold, and is then filtered through a hard paper. Students prepare extracts of two types of meat given out, ${ }^{1}$ extracting 5 grams of chopped

1 One of these should if possible be horse meat which can usually be obtained from a board of health or a veterinary institution. The antihorse serum is prepared in advance by the injection of three rabbits with horse serum. (Lesson I.) If it is not possible to obtain horse flesh, the whole experiment can be done with antisheep serum and mutton obtained from a butcher. 

meat with 5 c.c. of salt solution and filtering. The clear solution represents approximately a 1-100 dilution of the protein. From it a 1-1000 dilution should be prepared.

The following experiment should then be set up :

\begin{tabular}{|c|c|c|c|c|}
\hline TUBE & ANTIGEN & & ANTIHORSE SERUM & Guinea Pig Serum 1-10 \\
\hline 1 & Extract A (1-100) & 0.5 c.c. & 0.1 c.c. & 0.5 c.c. \\
\hline 2 & Extract A (1-1000) & 0.5 c.c. & 0.1 c.c. & 0.5 c.c. \\
\hline 3 & Extract B (1-100) & 0.5 c.c. & 0.1 c.c. & 0.5 c.c. \\
\hline 4 & Extract B (1-1000) & 0.5 c.c. & 0.1 c.c. & 0.5 c.c. \\
\hline 5 & $\begin{array}{l}\text { Extract A ( } 1-100) \\
\text { (Antigen control) }\end{array}$ & 1.0 c.c. & 一 & 0.5 c.c. \\
\hline 6 & $\begin{array}{l}\text { Extract B }(1-100) \\
\text { (Antigen control) }\end{array}$ & 1.0 c.c. & 一 & 0.5 c.c. \\
\hline 7 & Antiserum control & 一 & 0.2 c.c. & 0.5 c.c. \\
\hline 8 & Complement control & $1-$ & - & 0.5 c.c. \\
\hline
\end{tabular}

All tubes are to be brought up to a volume of 1.5 c.c. by the addition of salt solution.

Incubate for one hour at $37.5^{\circ} \mathrm{C}$.

At the end of this time 0.5 c.c. red cells, sensitized with two units of amboceptor, are added to each tube and the tubes are again incubated until hæmolysis is complete in controls " 5 ," " 6 ," " 7 " and " 8 ."

The purpose of the control tubes " 5 " and " 6 " is, of course, to prove that the antigen alone without the presence of the antiserum does not interfere with the complement action of the guinea pig serum, while the purpose of the control number " 7 ", is to make certain that the antiserum alone does not interfere with the action of the complement. Tube " 8 " is put in for a similar purpose so that a slight inhibitory action (anticomplementary effect) on the part of either antigen or antiserum can be recognized by contrast with the complete laking which ensues from the unhampered effect from the guinea pig serum on the sensitized red cells.

\section{Materials}

Each student requires:

5 grams of each of 2 types of chopped meat (horse and any other variety).

2 hard filter papers and funnels.

1 c.c. antihorse serum

5 c.c. guinea pig serum (1-10).

20 units antisheep-cell amboceptor.
8 one-c.e. pipettes.

8 half-inch test tubes.

2 large test tubes or wide mouth bottles.

1 test tube rack

5 c.c. sheep cells.

Salt solution. 



\section{LESSON XIX}

\section{WASSERMANN REACTION ${ }^{1}$}

\section{I}

\section{Preparation of the Antigen}

THE general principles of the technique of the Wassermann reaction are the same as those of other forms of complement fixation already discussed - with one notable exception: the antigen is not specific in origin, i.e., is not made from Spirochæta pallida or (as it originally was) from syphilitic organs. Landsteiner and his successors found that equally good or better results could be obtained with lipoidal substances extracted from normal organs by means of alcohol and other lipoid solvents. Various lipoid mixtures are now used, the most serviceable being alcoholic extracts of normal heart muscle, - usually beef, guinea pig, or human heart. Sometimes cholesterin is added to the alcoholic extract. The alcoholic solution, of course, is well diluted with saline solution before use. These facts, empirically ascertained since the introduction of the Wassermann reaction, show definitely that this test is not dependent upon an antigenantibody union as is the case with other forms of complement fixation.

No matter what lipoid antigen is used, its specificity and dosage have to be determined by careful preliminary titrations and by trial on known syphilitic and non-syphilitic sera before it can be used in diagnostic work.

As the preparation of antigen for use in the Wassermann test takes time it had better be begun about three weeks before the antigen is needed for the experiments below. The preparation of three typical and useful antigens will be described. The class should be divided into three groups of students and each group of students should be made jointly responsible for the preparation of one or two specimens of one of the types of antigen.

${ }^{1}$ Lessons XIX and XX should be repeated - if possible, an entire week given to them. 

A

SIMPLE ALCOHOLIC EXTRACT OF HEART MUSCLE

Human, guinea pig, and beef heart are used by different workers and are of practically equal value. Heart muscle is finely chopped and extracted at $37^{\circ} \mathrm{C}$. in 10 volumes of absolute alcohol, for from three to seven days. The jars in which the heart muscle is kept should be shaken one or more times a day. If guinea pig hearts are used, a jar of 100 c.c. of absolute alcohol is set aside, and the hearts are ground up and dropped into the alcohol whenever a guinea pig has to be killed for any laboratory purpose. It is important to remove all blood from the heart. If beef or human heart is used it is important to remove all fat and tendon before the heart is extracted. At the end of the period of extraction the alcohol is filtered and the filtrate tested as described below.

\section{B}

\section{CHOLESTERIN REËNFORCED HEART EXTRACT}

The guinea pig hearts ${ }^{1}$ are weighed before being added to the alcohol. Thirty grams of finely ground heart are extracted at least 14 days at $37^{\circ} \mathrm{C}$. with 300 c.c. of absolute alcohol. This is then filtered and half the filtrate is placed in a flask with an excess (say 5 grams) of chemically pure cholesterin. This is kept at $37^{\circ} \mathrm{C}$. overnight and then in a water bath at $16^{\circ} \mathrm{C}$. for three hours (to precipitate excess of cholesterin). This saturated solution is then filtered and the other half of the original heart extract is added to it, giving a heart extract which is half saturated with cholesterin.

\section{- $\mathrm{C}$}

\section{NOGUCHI'S ACETONE-INSOLUBLE FRACTION OF HEART EXTRACT}

Whereas in the preceding antigen cholesterin was added to the heart extract, Noguchi obtains a highly specific antigen by removing the cholesterin and certain other substances from the heart extract by means of precipitation with acetone (in which

\footnotetext{
1 Some workers use human or beef hearts.
} 

cholesterin is soluble whereas lecithin and certain allied lipoids are insoluble in it).

Extract 100 grams of mashed heart muscle with a liter of absolute alcohol at $37^{\circ} \mathrm{C}$. for several days. Filter and evaporate to dryness with an electric fan. This usually takes 12 to 24 hours. Dissolve the residue in ether (avoid flames). Stand the milky ether solution in the ice box overnight and decant off the clear supernatant portion. Evaporate this before an electric fan to a small volume and to it add about 10 volumes of pure acetone. Allow to stand for several hours and decant off the acetone. Scrape the precipitate off with a spatula and preserve it under acetone. For use dissolve about 0.3 grams of the brownish sticky precipitate in 1 c.c. of ether and to it add 9 c.c. methyl alcohol. The alcohol solution is fairly stable and can be used as a stock solution.

\section{II}

\section{Titration of Wassermann Antigen}

Alcoholic extracts of organs contain substances which are hæmolytic and substances which have the power of binding complement non-specifically, much as do bacterial suspensions and extracts. They also contain substances which in combination with syphilitic sera have the power of binding complement. It is important to test for all three of these properties and a suitable extract must show an antigenic value (that is, the power to bind complement in the presence of syphilitic serum) much higher than its anticomplementary or hæmolytic values. The hæmolytic power of the antigen seldom interferes practically, and is somewhat interfered with by the guinea pig and human serum used in the test.

Before standardizing the antigen, the alcoholic concentrated antigen should be diluted 1-10 with salt solution, and the way in which this suspension is made is of importance since the antigen is in colloidal suspension and not in true solution and the anticomplementary and antigenic value depend certainly in part on the physical condition of the antigen. This will vary according 

to whether the alcoholic extract is run rapidly into the salt solution which is used as diluent or whether the extract is diluted by dropping salt solution into it. It is not of so great importance which of the two methods is used as that the same method should be used throughout both preliminary titrations and tests.

Each student tests one of the three antigens made by the class. This antigen is to be made up to a 1-10 dilution with saline. Add the saline slowly to the antigen. Each student needs about 10 c.c. of the 1-10 dilution.

A syphilitic (Wassermann ++++ ) and a normal human serum containing no or very little antisheep-cell amboceptor are chosen: they are inactivated at $56^{\circ} \mathrm{C}$. for half an hour before use.

Set up the following series of tubes :

$\begin{array}{lcc}\text { 1. Determination of Anticomplementary Dose } \\ \text { Tube } & \text { Antigen } 1-10 & \text { Complement } 1-10 \\ 1 & 0.2 \text { c.c. } & 2 \text { units } \\ 2 & 0.4 \text { c.c. } & 2 \text { units } \\ 3 & 0.8 \text { c.c. } & 2 \text { units } \\ 4 & 1.2 \text { c.c. } & 2 \text { units } \\ 5 & 1.6 \text { c.c. } & 2 \text { units } \\ 6 & 2.0 \text { c.c. } & 2 \text { units }\end{array}$

2. Demonstration that Antigen is not Hamolytic of Itself Tube 7 Antigen 1-10 1.0 c.c. $5 \%$ Sheep cells 0.5 c.c.

3. Determination of Antigenic Dose

\begin{tabular}{|c|c|c|c|}
\hline Tube & Antigen & Syphilitic $(++++)$ Serum $^{1}$ & Complement 1-10 \\
\hline 8 & $(1-40) 0.05$ c.c. & 0.1 c.c. & 2 units \\
\hline 9 & $(1-40) 0.1$ c.c. & 0.1 c.c. & 2 units \\
\hline 10 & $(1-40) 0.2 \quad$ c.c. & 0.1 c.c. & 2 units \\
\hline 11 & $(1-10) 0.1$ c.c. & 0.1 c.c. & 2 units \\
\hline 12 & $(1-10) 0.2$ c.c. & 0.1 c.c. & 2 units \\
\hline 13 & $(1-10) 0.4$ c.c. & 0.1 c.c. & 2 units \\
\hline
\end{tabular}

4. Proof that Antigen is Specific (Negative Control) $\begin{array}{cccc}\text { Tube } & \text { Antigen } 1-10 & \text { Normal Human Serum } & \text { Complement } 1-10 \\ 14 & 0.1 \text { c.c. } & 0.1 \text { c.c. } & 2 \text { units } \\ 15 & 0.2 \text { c.c. } & 0.1 \text { c.c. } & 2 \text { units } \\ 16 & 0.4 \text { c.c. } & 0.1 \text { c.c. } & 2 \text { units }\end{array}$

1 The sera used should be inactivated on day of test by heating to $55^{\circ}$ for twenty minutes in the water bath. 



\section{Serum Controls}

$\begin{array}{ccr}\text { Tube } & \text { Normal Serum } & \text { Complement } \\ 17 & 0.1 \text { c.c. } & 2 \text { units } \\ 18 & 0.2 \text { c.c. } & 2 \text { units } \\ & \text { Syphilitic }(++++) \text { Serum } \\ 19 & 0.1 \text { c.c. } & 2 \text { units } \\ 20 & 0.2 \text { c.c. } & 2 \text { units }\end{array}$

The volume is made to 2 c.c. as nearly as possible in all the tubes.

All tubes are put in water bath for one hour. Then 0.5 c.c. of 5 per cent sheep cells and two units of amboceptor are added to each tube (except 2 tube 7) and the tubes are all returned to the water bath for thirty minutes.

\section{Conclusions to BE DRAWN FROM the Above}

\section{Series 1}

The anticomplementary dose is that quantity of antigen which shows the slightest inhibition of laking. The amount of antigen used in the test must under no circumstances exceed one half of this amount and is usually taken as one third of it. Thus if Tube 5 containing 1.6 c.c. of the 1 to 10 antigen shows a faint haze of undissolved red cells, then the quantity used in the tests should not exceed 0.5 c.c.

\section{Series 2}

An antigen which is hæmolytic in itself in Tube 7 is rejected as useless. When the extractions are made of normal heart this occurrence is rare.

\section{Series 3}

The antigenic dose is the smallest amount that gives complete inhibition in the presence of syphilitic serum. This is tested in Tubes 8 to 13 . In order that an antigen be of value the antigenic dose must be considerably smaller than the anticomplementary quantity determined in Series 1 . It is desirable in the tests to use an amount of antigen containing at least several antigenic units. Thus, if the antigen tested shows complete inhibition in Tube 11 and merely partial inhibition in Tube 10, 

and perhaps none in 8 and 9 , then the quantity contained in Tube 11, namely 0.1 c.c. of the 1 to 10 dilution, is the antigenic dose or unit. It is desirable to use 4 or 5 times this unit in the test, and if this quantity does not exceed one third of the anticomplementary dose determined in Series 1 , the antigen is suitable for use.

\section{Series 4}

The object of Series 4 is of course to show that inactivated normal sera do not fix complement in the presence of the antigen. In practice no worker should be satisfied to test a new antigen against merely one normal serum, but before using the antigen in routine tests it should be used for some time parallel with an old familiar antigen.

\section{Series 5}

Series 5 controls the positive and negative sera used in the preceding series. They are carried out because under certain circumstances sera become anticomplementary, especially if kept for several days. If this occurs, the anticomplementary property can usually be destroyed by heating to $56^{\circ} \mathrm{C}$. However, occasionally even inactivated sera may remain slightly anticomplementary. Therefore these controls are indispensable.

\section{Materials}

Each student needs :

1.0 c.c. antigen (undiluted).

10.0 c.c. complement (1-10).

15.0 c.c. 5 per cent sheep cells.

45 units amboceptor.

1.0 c.c. positive $(++++)$ serum.

1.0 c.c. negative serum.

Salt solution.

25 half-inch test tubes.

5 one-inch test tubes.

8 one-c.c. pipettes.

1 two-c.c. pipette.

1 five-c.c. pipette.

1 test tube rack.

Electric fan. 



\section{LESSON XX}

\section{WASSERMANN REACTIONS}

\section{II \\ Technique of Tests \\ I. Preliminary Complement Titration}

ON account of the complement variability of guinea pigs' serum and of the desirability of using a uniform amount of complement, a fresh titration of the complement is done on each occasion when Wassermann tests are performed. In order to allow a margin of safety, twice that amount of guinea pigs' serum is used in the tests which in the preliminary titration gives complete laking with 2 units of amboceptor in 15 minutes.

(The quantities of all the ingredients given here are known as "half Wassermann" quantities; that is, for the sake of economy and convenience half the amount of patients' serum, guinea pig serum, sheep cells, etc., described in the original Wassermann test are used and the total volume is made to 2.5 c.c. instead of 5 c.c. Some workers carry economy farther and use "tenth Wassermann" quantities.

There are also some workers who instead of redetermining the dose of complement each time, keep the dose of complement constant 0.5 c.c. of 10 per cent serum for half Wassermanns - and redetermine the amboceptor unit. The net result is not very different, but since the guinea pig is the variable factor it seems more reasonable to vary the amount of guinea pigs' serum.)

Into each of 7 tubes put 0.5 c.c. of 5 per cent sheep cells, two units of amboceptor and 10 per cent complement (fresh guinea pig serum) in the following amounts: ${ }^{1}$

\begin{tabular}{c|c|c|c}
\hline \hline Tube & Sheep Cells & Sensitizer or Amboceptor & $\begin{array}{c}\text { Complement } 10 \% \text { in Salt } \\
\text { Solution }\end{array}$ \\
\cline { 2 - 4 } 1 & 0.5 c.c. & 2 units & 0.1 c.c. \\
2 & 0.5 c.c. & 2 units & 0.15 c.c. \\
3 & 0.5 c.c. & 2 units & 0.2 c.c. \\
4 & 0.5 c.c. & 2 units & 0.25 c.c. \\
5 & 0.5 c.c. & 2 units & 0.3 c.c. \\
6 & 0.5 c.c. & 2 units & 0.4 c.c. \\
7 & 0.5 c.c. & 2 units & 0.5 c.c. \\
8 & 0.5 c.c. & - & 0.5 c.c. \\
\hline \hline
\end{tabular}

Bring the volume of all the tubes up to 2.5 c.c. by addition of saline solution.

1 The following is the preferable order of adding the reagents:

First pipette the complement, second the amboceptor, third the saline solution and last the red cells, shaking the tubes thoroughly while the cells are being added. 

Set up one tube (complement control) with 0.5 c.c. of sheep cells and 0.5 c.c. of complement only, in order to make sure that the guinea pig serum alone is not at all hæmolytic.

For the tests twice that amount of complement is used which just gives complete hæmolysis in 30 minutes. With average guinea pigs 0.25 c.c. gives this and 0.5 is used in the test.

\section{Preparation of Serum}

Inactivate at $56^{\circ} \mathrm{C}$. for one half hour a known syphilitic and a known normal serum and one or more sera to be examined.

\section{Setting up the Tests. Primary Incubation}

Test tube racks with two rows of holes are used so that each serum may have a "front" tube and a corresponding "back" tube.

(a) Into each of a pair of 5 c.c. test tubes measure 0.1 c.c. of each of the sera.

(b) Into one (the front tube) of each pair measure a dose of diluted antigen. (The dose is one third of the largest amount which by previous titration has been found not to interfere with the action of the amount of complement used in the test.)

Into an extra tube measure two doses of antigen (antigen control tube).

(c) Into all tubes measure the predetermined dose of complement. Shake each tube at once. Add enough saline to make the contents of all the tubes approximately 2 c.c.

(d) Incubate in water bath for one hour at $37^{\circ} \mathrm{C}$. (With certain antigens, as for instance with alcoholic heart extracts, somewhat more delicate results can be obtained by a four hour preliminary incubation in the ice box at $8^{\circ}-12^{\circ} \mathrm{C}$. For class work, however, this is impractical.)

\section{Addition of Hemolytic System. Secondary Incuba- tion. Reading of Results}

Into all tubes measure 0.5 c.c. of 5 per cent sheep cells to which 2 units of amboceptor have been added. Incubate at $37^{\circ} \mathrm{C}$. Read the results when the double antigen tube and all the serum control tubes (i.e. those containing no antigen) are completely laked.

Fill out a protocol of the degree of inhibition, if any, in the various tubes: 



\begin{tabular}{|c|c|c|c|}
\hline & $\begin{array}{c}\text { INHIBITION SHOWN } \\
\text { IN TEST }\end{array}$ & $\begin{array}{l}\text { INHIBITION SHOWN } \\
\text { IN CONTROL (WITH- } \\
\text { OUT ANTIGEN) }\end{array}$ & $\underbrace{\text { RESUT }}_{\text {WABSERMAT OF }}$ \\
\hline $\begin{array}{l}\text { Positive serum } \\
\text { Negative serum } \\
\text { Unknown serum } 1 \\
\text { Unknown serum } 2 \\
\text { Unknown serum } 3 \\
\text { Double dose of antigen }\end{array}$ & & & \\
\hline
\end{tabular}

Each student needs:

One known syphilitic serum. 7 c.c. of $10 \%$ complement. Five $\frac{3}{4}$-inch test tubes. Racks. 10 one-c.c. pipettes.

One normal serum. $20 \frac{1}{2}$-inch test tubes.

\section{LESSON XXI}

\section{COMPLEMENT FIXATION WITH BACTERIAL EXTRACTS}

ON account of the rather high anticomplementary strength of the insoluble portion of bacterial bodies themselves, in practical complement fixation tests the effort is made to obtain the antigenic substance of the microörganisms in more or less pure solution. This is partially accomplished by extracting with distilled water, by mechanical breaking up of the bacterial bodies, etc. Bacterial complement fixation with antigens of this type is of practical diagnostic use in gonorrhea, glanders, typhoid fever, whooping cough and other diseases.

Cultures of the same species of organism isolated from different sources often show considerable biological differences, and an immune serum which fixes complement with one such strain often gives only partial fixation with another. For this reason, in diagnostic tests, polyvalent antigens are used, i.e., antigens made of numerous different strains of the bacteria in question.

On account of the prolonged manipulations required students will not make bacterial antigens for these tests, ${ }^{1}$ but will be pro-

1 The technique of preparing the Gonococcus antigen as practiced at the New York Board of Health and supplied to us by the kindness of Miss M. P. Olmstead is as follows:

The strains used in the polyvalent antigen are ten of those shown by Torrey to be serologically distinct - A, B, C, G, K, L, N, O, Q, S.

Stock transplants are kept on glucose ascitic agar, prepared as follows :

Bob veal, lean, chopped fine

Distilled $\mathrm{H}_{2} \mathrm{O}$

$1 \mathrm{lb}$.

1 liter.

Mix, stand overnight at room temperature. Heat to $45^{\circ} \mathrm{C}$. one hour. 

vided with extracts already made which require only to be properly diluted with saline before use, and with these extracts will do fixation tests for Gonococcus and for Glanders.

Bring to a boil. Strain through cheese cloth.

Bring to original volume. Add agar $1 \frac{1}{2}$ per cent, Witte's peptone 2 per cent, $\mathrm{NaCl} \frac{1}{2}$ of 1 per cent.

Titrate. Reaction should be neutral to phenolphthalein.

Filter through a filter made with a layer of cotton, one of filter paper, another layer of cotton. Filter several times.

Autoclave $\frac{1}{2}$ hour at $15 \mathrm{lb}$. pressure.

Glucose 2 per cent.

10 grams of glucose dissolved in 50 c.c. distilled $\mathrm{H}_{2} \mathrm{O}$. Sterilize three days for 20 minutes in Arnold.

Ascitic fluid 20 per cent.

Ascitic fluid is filtered through Berkefeld, sealed in sterile flasks, incubated at $37.5^{\circ}$ several days before using. Glucose solution and ascitic fluid are mixed before adding to tubed and sterilized agar. Incubate tubes. Keep two days before using.

Transplant the stock cultures every 48 hours. The gonococcus must always be kept at $37.5^{\circ} \mathrm{C}$. Any inequality of temperature will cause a poor growth of the organism.

For the antigen transplants use veal agar prepared as above, except that salt, glucose and ascitic fluid are omitted. The reaction should be very carefully adjusted; it should be neutral at the last titration before autoclaving, and when ready to use 0.1 to 0.2 per cent acid, preferably 0.1 per cent. Medium is titrated hot with $\mathrm{N} / 20 \mathrm{NaOH}$. No ehange should take place when phenolphthalein is added. One or two drops of $\mathrm{NaOH}$ produce a faint pink color which disappears on adding one or two drops of $\mathrm{N} / 20 \mathrm{HCl}$. The agar is then bottled and autoclaved one half hour at $15 \mathrm{lb}$. pressure.

To prepare antigen take 24-hour stock cultures and transplant to potato tubes (tube $6 \times 1$ inch) of salt free veal agar neutral to phenolphthalein. Incubate 24 hours. Transfer all this growth by means of sterile cotton swabs to wide-mouthed Blake bottles (one tube to a bottle) containing neutral salt free veal agar, gently rubbing the swab over the entire surface of the agar. Incubate for 24 hours. Wash off all this growth, if good, with neutral sterile distilled water, 10 e.c. to a bottle. If the growth is poor, 5 c.e. is sufficient. The bottle should be gently tipped back and forth two or three times after the water is added and the growth scraped off lightly with a bent glass rod. Do not allow the water to remain on the agar more than a few seconds. The resulting emulsion is autolyzed for one hour in a water bath at $56^{\circ} \mathrm{C}$. and at $80^{\circ} \mathrm{C}$. for one hour. Filter the autolyzed emulsion through a Buchner funnel which has been well packed with paper pulp and then through a sterile Berkefeld filter of $\mathrm{N}$ or $\mathrm{V}$ porosity.

As new filters are very alkaline they are taken to pieces before use and boiled in distilled water at least three times, five minutes each time, being scrubbed thoroughly with a small brush in fresh water after each boiling. Then the filter is set up and hot distilled water allowed to stand in it for five minutes. Hot neutral distilled water is then run through it under gentle pressure until fluid is clear and neutral when tested with phenolphthalein. After a filter has been used 



\section{Gonococcus Complement Fixation}

The antigen provided is a distilled-water extract. It is to be diluted 1-10 with 0.9 per cent saline solution. The preliminary titration is done exactly as with the typhoid emulsion in Lesson XVI in order to determine the "anticomplementary dose" of the antigen. That amount which just shows beginning inhibition of hæmolysis when two units of amboceptor and two units of complement ( 0.5 c.c. of 1-10 dilution) are used is designated the anticomplementary dose, and one quarter of this dose is used as the dose of antigen in the test. Supposing that this anticomplementary dose is found (with 0.5 c.c. of 1-10 guinea pig serum, 0.5 c.c. of 5 per cent sheep cells, and two units of amboceptor) to be 2.0 c.c., then the tests are set up as follows:

\begin{tabular}{c|c|c|c}
\hline \hline Tube & & Antigen & $\begin{array}{c}\text { Guinea Pig } \\
\text { SERUM 1-10 }\end{array}$ \\
\cline { 2 - 3 } 1 & Positive serum 0.1 c.c. & 0.5 c.c. & 2 units \\
2 & Negative serum 0.1 c.c. & 0.5 c.c. & 2 units \\
3 & Positive serum 0.2 c.c. & - & 2 units \\
4 & Negative serum 0.2 c.c. & - & 2 units \\
5 & - & 1.0 c.c. & 2 units \\
6 & - & 2.0 c.c. & 2 units \\
\hline \hline
\end{tabular}

Bring up to 2.0 c.c. with salt solution.

Incubate one hour in the thermostat at $37^{\circ} \mathrm{C}$. or if possible four hours in the ice box at $10^{\circ} \mathrm{C}$. Then add 0.5 c.c. sheep cells sensitized with two units of amboceptor and incubate at $37^{\circ} \mathrm{C}$. until all the tubes excepting Tube 1 are completely laked. The positive serum is either the serum of a rabbit which has been immunized with gonococci or the serum of a patient known by previous tests to have a positive gonococcus fixation reaction. All the sera are of course inactivated at $56^{\circ} \mathrm{C}$. for a half hour before use.

it is boiled in distilled water and thoroughly scrubbed. It may be dried in the air for $\mathbf{4 8}$ hours and put away or attached to a filter flask and sterilized to be ready for use. Do not use for filtering gonococcus antigen a filter that has been used for any other purpose, unless it is first boiled in 1 per cent $\mathrm{NaOH}$ and reneutralized.

Bottle the filtrate with aseptic precautions. Sterilize three successive days for one half hour each day at $56^{\circ} \mathrm{C}$. and keep in the ice box. Immediately before use the antigen is made isotnie by the addition of one part 9 per cent saline solution to nine parts antigen. The antigen is more likely to remain stable if no salt is added until the day of use. 



\section{II}

\section{Glanders Complement Fixation}

This is carried out in the same manner as the gonococcus test, using the serum of a known glanders-infected horse as a positive control. ${ }^{1}$

\begin{tabular}{|c|c|c|c|}
\hline TUBE & & Antigen & Guinea Pig Serum $1-10$ \\
\hline $\begin{array}{l}1 \\
2 \\
3 \\
4 \\
5 \\
6 \\
7\end{array}$ & $\begin{array}{lll}\text { Positive serum } & 0.1 & \text { c.c. } \\
\text { Negative serum } 0.1 & \text { c.c. } \\
\text { Positive serum } & 0.2 & \text { c.c. } \\
\text { Negative serum } & 0.2 & \text { c.c. } \\
\square & \end{array}$ & $\begin{array}{l}0.5 \text { c.c. } \\
0.5 \text { c.c. } \\
- \\
1.0 \text { c.c. } \\
2.0 \text { c.c. } \\
\text { - }\end{array}$ & $\begin{array}{l}0.5 \text { c.c. } \\
0.5 \text { c.c. } \\
0.5 \text { c.c. } \\
0.5 \text { c.c. } \\
0.5 \text { c.c. } \\
0.5 \text { c.c. } \\
0.5 \text { c.c. }\end{array}$ \\
\hline
\end{tabular}

Bring up to 2.0 c.c. with salt solution.

Incubate one hour in the thermostat at $37^{\circ} \mathrm{C}$. or if possible four hours in the ice box at $10^{\circ} \mathrm{C}$. Then add 0.5 c.c. sheep cells sensitized with two units of amboceptor and incubate at $37^{\circ} \mathrm{C}$. until all tubes excepting Tube 1 are.completely laked. The positive serum is from a glandered horse known to be positive by previous tests.

Materials needed for each student for gonococcus fixation :

0.5 c.c. positive serum.

0.5 c.c. normal serum.

5.0 c.c. antigen (diluted).

5.0 c.c. guinea pig serum (1-10).

5.0 c.c. sheep cells 5 per cent suspension. 10 one-c.c. pipettes (graduated).
20 units amboceptor.

20 half-inch test tubes Salt solution.

1 test tube rack.

\section{Glanders Antigen}

${ }^{1}$ The technique of preparing glanders antigen as practiced at the New York Board of Health and supplied to us by the kindness of Miss M. P. Olmstead is as follows:

Stock transplants are kept on glycerine potato agar (for formula see Park and Williams' Pathogenic Microörganisms, 1914, page 97) from 1 per cent to 2 per cent acid to phenolphthalein. For antigen transplants the same medium is used as in the preparation of gonococcus antigen, except for the reaction, which should be 1.6 per cent acid. The 24 hour growth on bottles is washed off with sterile, neutral, distilled water and heated at $80^{\circ} \mathrm{C}$. for 6 to 8 hours, then filtered. With the exceptions mentioned, the technique of antigen preparation is the same as in the case of gonococcus. 

Materials needed for each student for glanders fixation:

0.5 c.c. positive glanders serum from a horse known to be infected and giving a positive glanders complement fixation reaction.

0.5 c.c. normal horse serum.

5.0 c.c. glanders antigen.

5.0 c.c. guinea pig serum (1-10).

5.0 c.c. 5 per cent sheep cells.

20 units amboceptor.

20 half-inch test tubes.

10 one-c.c. graduated pipettes.

1 test tube rack.

Salt solution.

\section{LESSON XXII}

\section{THE STANDARDIZATION OF DIPHTHERIA ANTITOXIN}

(THE proper understanding of the work in this lesson requires a review of the constitution of diphtheria toxins and the theoretical principles involved. The student should read again the section on toxin and antitoxin in Infection and Resistance, in Kolmer's Infection and Immunity, in Paul Th. Müller's Vorlesungen über Infektion und Immunität, in the Krause und Levaditi Handbuch, or in some other work in which these principles are discussed at length.)

When extensive therapeutic use first necessitated the establishment of a standard of dosage for diphtheria antitoxin, it was hoped that a method could be developed depending upon simple in vitro titration analogous to the titration of normal acid against normal alkali solutions, in which the unknown antitoxin could be measured against known amounts of a standard toxin. Since no visible or chemically determinable reaction takes place between the two substances in the test tube, the only method of ascertaining whether or not the given quantity of toxin was neutralized by the antitoxin was to inject the two substances, at first separate but later previously mixed, into susceptible animals and learn from the result whether or not free, unneutralized toxin was left. The guinea pig, chosen as the most suitable test animal, therefore, took the place in these reactions of the "indicator" to demonstrate 

the presence of free, unneuiralized toxin by its death, just as phenolphthalein in.acid-alkali titrations indicates the presence of free alkali by a pink color. Since guinea pigs of different weights and ages have varying resistances against the poison, a standard weight for such measurements, namely 250 grams, was established.

The first step toward such a standardization, of course, consisted in establishing standards of measurement for toxin. Behring, later together with Ehrlich, established as a toxin unit or MLD (minimal lethal dose) the amount of a toxin solution which would kill a guinea pig of 250 grams. Because of the importance of the time element this was later modified to represent the amount which would kill such a guinea pig in from four to five days.

The antitoxin unit later established mainly by the efforts of these two workers was designated as the amount of the antitoxin, i.e. of the serum of a toxin immune animal, which would neutralize 100 such MLD's (minimal lethal doses) for guinea pigs of the standard weight. It was soon found by these workers, as well as by others, that it was not easy to determine the exact point of neutralization, that is, while the guinea pig might be preserved from death from 100 such minimal lethal doses, in one case in another slight local or systemic symptoms might easily escape the observation of the investigator, and it seemed safer to eliminate the personal equation entirely. This was done by establishing as an antitoxin unit not the amount that would neutralize the 100 fatal doses, but a partial neutralization measured in such a way that the toxin quantity left over in the mixture would still kill the guinea pig in four to five days, giving the same effect as an unneutralized single toxin unit.

Subsequent developments in the investigation of toxins, especially by Ehrlich, disclosed many difficulties in the path of such a relatively simple method of titration. It is a comparatively easy matter to determine the minimal lethal dose of any poison that one may have produced. However, this quantity - or MLD - will not be identical in one and the same toxin filtrate if this is measured at intervals of a few weeks or months, since the true toxin is gradually converted into a non-poisonous prod- 

uct, the "toxoid." The toxoid is not poisonous for guinea pigs, and therefore the volume of original broth necessary to kill guinea pigs of the required weight increases. Now if this deterioration into toxoid implied at the same time diminution of neutralizing power for antitoxin the titration could be easily adjusted by simply remeasuring the minimal lethal dose for the particular solution used and proceeding on this basis merely with a changed unit. However, in old toxin solutions, although the minimal lethal dose is larger, the neutralizing value of this poison for antitoxin has changed very little or not at all. In other words, the toxin derivatives or toxoids, although no longer poisonous to the guinea pig, still retain their neutralizing power for the antitoxin. It is obvious therefore that no constant standard could be obtained merely by measuring the minimal lethal dose of any toxin broth and measuring the antitoxin unit against 100 such minimal fatal doses. The amount of toxoid would be alike in no two toxin filtrates nor in the same filtrate at different times, and the antitoxin unit which I determined against 100 MLD's of a toxin brothI have produced in my laboratory might be far different in antitoxic potency from a unit similarly determined in another laboratory from another toxin broth containing an entirely different proportion of true toxin and non-poisonous antitoxin-neutralizing toxoids.

In consequence a different system has had to be worked out largely by the laborious investigations of Ehrlich. Ehrlich found that the antitoxin was very much more stable than the toxin. If dried, reduced to a powder, and preserved in vacuo in a small glass $U$-tube over phosphoric anhydride in the cold and in the dark, such dried serum would preserve its antitoxic value for a long time and no deterioration comparable to that taking place in the toxin would occur. Originally Ehrlich prepared tubes in this way, each one containing antitoxin powder of a potency of 1700 antitoxin units to the gram, these antitoxin units being measured against one of the toxins in his possession representing the amount necessary to neutralize 100 MLD's of this toxin. Against this powder then from time to time other toxins are measured and the quantity determined which mixed 

with such an antitoxin unit will just kill a guinea pig of 250 grams in from four to five days, i.e. which mixed with one standard antitoxin unit will give the effects of one free toxin unit. This amount of toxin is known as the $\mathrm{L}+$ dose, and of course if such an $\mathrm{L}+$ dose of a toxin measured against the standard unit is now mixed with varying quantities of an unknown antitoxin until a mixture of similar effect is obtained, the particular quantity of antitoxin used in this mixture will be equal to the original standard antitoxin unit. Thus the antitoxin unit established by Ehrlich is now the standard of measurement for other antitoxins rather than the toxin itself.

Such standard antitoxin units are preserved in the way indicated above for America at Washington, for Germany in Frankfort, for France at Paris, etc., and the $\mathrm{L}+$ dose of toxin solutions can be determined against these standards and with such L + quantities of any given toxin new antitoxin can be standardized and portions of these in turn preserved. Constancy of measurement is thereby assured if this system is kept under proper governmental supervision without a break in continuity, and without accident. This is practically insured against by the large number of laboratories in the world in which this standard is being kept.

It is obvious therefore that in the investigation of antitoxic strength three standard units are used. They may be defined as follows :

The Minimal Lethal Dose (MLD or T) is that amount of toxin which when subcutaneously injected invariably causes the death of a 250-gram guinea pig in from four to five days.

Limes "Zero" Dose $\left(\mathrm{L}_{0}\right)$ is that amount of toxin which is completely neutralized by one antitoxin unit so that no trace of reaction, local or otherwise, ensues when it is injected mixed with one unit of antitoxin.

Limes "Todt" Dose $(\mathrm{L}+)$ is that amount of toxin which when mixed with one unit of antitoxin and injected subcutaneously will cause the death of a 250 -gram guinea pig in four to five days.

The quantitative relationship between the MLD, the $\mathrm{L}_{0}$ dose 

and the $\mathrm{L}+$ dose is one that is by no means regular, an irregularity which has not yet met with an entirely satisfactory explanation and which for the actual practical measurement of antitoxin it is not necessary to go into at present. The student, however, is advised again to refer to the textbooks mentioned above and to read the explanations of this subject carefully. It is easily seen, however, that the definition of an antitoxin unit as it is at present used can no longer be truthfully given as the amount which neutralizes 100 fatal doses for guinea pigs of 250 grams, although this is the way it is usually put in textbooks. The original unit measured by Ehrlich and preserved did actually neutralize 100 fatal doses of the particular toxin used. However, when the stated amount of this original antitoxin [or of other antitoxins based upon it and similarly preserved] is measured against many other and unknown toxins, the $\mathrm{L}+$ dose of these poisons containing amounts of toxoid differing from that in Ehrlich's original toxin will not necessarily contain 100 minimal lethal doses of true toxin. The antitoxin in such mixtures is neutralized not only by the true toxin but also by the toxoid which has different or no poisonous properties, and thus the number of actual minimal lethal doses contained in the mixture may vary from 50 up. An antitoxin unit, therefore, in the modern sense is the amount of antitoxin which when mixed with the $\mathrm{L}+$ dose of a standard toxin leads to death of the guinea pig in four to five days. The $\mathrm{L}+$ dose of the toxin in this case must have been measured by a previously determined standard antitoxin unit which is the ultimate basis of measurement.

In order to allow a margin of safety this definition has been further altered of recent years in the following way:

The antitoxin unit is the amount of antitoxic serum which mixed with the $\mathrm{L}+$ dose of a standard toxin will preserve a guinea pig of 250 grams from death.

\section{Preparation of Toxin}

Each student is given a 500 c.c. Erlenmeyer flask in which is 100 c.c. of veal infusion broth containing 2 per cent peptone and adjusted to 

reaction of 0.5 per cent acidity to phenolphthalein. (Various modifications of this medium may be used. Smith recommends a broth which has been made sugar free by inoculation with colon bacillus, and Rosenau recommends the addition of 1 per cent glucose to the broth.) A strain of B. diphtheriæ known to produce strong toxin (preferably the ParkWilliams bacillus No. 8) is used for inoculation. Before it is planted on flasks it should be transferred by the instructor daily through a series of several broth tubes to obtain vigorous and rapid growth. The flasks are incubated for seven days and one or two which show the best growth filtered through a Berkefeld filter. The filtrate is stored in a sterile dark bottle on ice until used.

The class, working as a group, will carry out one or more of the following determinations on one such toxin, each student injecting one of the pigs in a given series. (In actual class work, in order to save guinea pigs, usually only III, the determination of the antitoxic value of an unknown serum, is carried out.)

\section{DETERMINATION OF THE MLD OF A TOXIN}

Guinea pigs are injected subcutaneously with varying amounts of this toxin until the amount is determined which will regularly cause death in from four to five days. For a satisfactory toxin the MLD must be less than 0.01 c.c. The toxin is diluted in salt solution so that the desired amount will be contained in 2 c.c. This amount is injected subcutaneously, with a Rosenau syringe, ${ }^{1}$ the needle of which is inserted in the flank of the guinea pig and passed subcutaneously in the flank of the pig till the point is near the linea alba before the diluted poison is injected. After injection 1 c.c. of salt solution is placed in the syringe without removing the needle and injected to wash out the last traces of the poison. The following example of such a determination is taken from Rosenau's toxin No. 5. The MLD in this case was .002 c.c.

\begin{tabular}{|c|c|c|c|}
\hline Dates Tebted & Animal & TOXXN INJECTED & Result \\
\hline $5 / 26 / 04$ & G.P. & .005 c.c. & Death 1 day 18 hours \\
\hline $5 / 26 / 04$ & G.P. & .005 c.c. & Death 1 day 20 hours \\
\hline $5 / 31 / 04$ & G.P. & .004 c.c. & Death 3 days 12 hours \\
\hline $5 / 31 / 04$ & G.P. & .003 c.c. & Death 2 days 12 hours \\
\hline $5 / 31 / 04$ & G.P. & .002 c.c. & Death 4 days 0 hours \\
\hline $7 / 21 / 04$ & G.P. \#105 & .001 c.c. & Death 5 days 5 hours \\
\hline $7 / 21 / 04$ & G.P. \# 107 & .0008 c.c. & Death 7 days 23 hours \\
\hline $9 / 30 / 04$ & G.P. \#311 & .002 c.c. & Death 4 days 3 hours \\
\hline $12 / 15 / 04$ & G.P. \# 1030 & .002 c.c. & Death 4 days 8 hours \\
\hline
\end{tabular}

1 Ordinary Luer or other all-glass syringes are used in many laboratories. 



\section{DETERMination OF THE L + DOSE OF toxin}

A dilution of a carefully standardized antitoxic serum is prepared in sterile salt solution so that each cubic centimeter contains one unit of antitoxin. A preliminary test with the dilutions spaced widely should be carried out by the instructor to determine approximately the $\mathrm{L}+$ dose. A series of dilutions of toxin increasing by about $\frac{1}{10}$ of the smallest amount should then be prepared, the total volume of each dilution being brought up to 2 c.c. (The smallest amount is the amount just below the minimal dose fatal when mixed with one unit of antitoxin in the preliminary experiment.) 1 c.c. of antitoxin is then mixed with 2 c.c. of each dilution of toxin in a Rosenau syringe and allowed to stand for one hour. The mixture is then injected into a 250 -gram pig, as in determining the MLD, and the syringe washed with 1 c.c. of salt solution.

If the preliminary test has shown the dose to be between 0.2 and 0.3 c.c. the test should be set up as follows :

\begin{tabular}{|c|c|c|c|}
\hline TUBE & ANTITOXIN & Toxin (1 IN 5) & Salt Solution \\
\hline $\begin{array}{l}1 \\
2 \\
3 \\
4 \\
5 \\
6\end{array}$ & $\begin{array}{l}1.0 \text { c.c. }(=1 \text { unit }) \\
1.0 \text { c.c. } \\
1.0 \text { c.c. } \\
1.0 \text { c.c. } \\
1.0 \text { c.c. } \\
1.0 \text { c.c. }\end{array}$ & $\begin{array}{l}1.0 \text { c.c. } \\
1.1 \text { c.c. } \\
1.2 \text { c.c. } \\
1.3 \text { c.c. } \\
1.4 \text { c.c. } \\
1.5 \text { c.c. }\end{array}$ & $\begin{array}{l}1.0 \text { c.c. } \\
0.9 \text { c.c. } \\
0.8 \text { c.c. } \\
0.7 \text { c.c. } \\
0.6 \text { c.c. } \\
0.5 \text { c.c. }\end{array}$ \\
\hline
\end{tabular}

If the pigs injected with the last two mixtures die on or before the fourth day, and those injected with the first four mixtures survive but possibly develop late paralysis, or if they die after the fifth day, the L+ dose is 1.4 c.c. of 1 in 5 toxin, or $0: 28$ c.c.

\section{DETERMINATION OF THE ANTITOXIC VALUE OF AN UNKNOWN SERUM}

The $\mathrm{L}+$ dose of a toxin having been carefully determined, this toxin may be used for standardizing an unknown antidiphtheritic serum by an analogous procedure. In this case the toxin is diluted so that 2 c.c. contain precisely the $\mathrm{L}+$ dose. Preliminary tests should be made to determine approximately the unit. Then an accurate test is carried out as follows:

If the serum is found in the preliminary determination to contain between 200 and 400 units per c.c. the dilutions are made as follows: A stock dilution of 1 c.c. of serum plus 19 c.c. of salt solution is prepared 

and the following series of dilutions accurately made from this in test tubes:

\begin{tabular}{r|c|c|c}
\hline TUBE & Antioxin & SAlt Solution & Dilution \\
\cline { 2 - 4 } 1 & 1.0 c.c. & 9.0 c.c. & $1-200$ \\
2 & 1.0 c.c. & 10.0 c.c. & $1-220$ \\
3 & 1.0 c.c. & 11.0 c.c. & $1-240$ \\
4 & 1.0 c.c. & 12.0 c.c. & $1-260$ \\
5 & 1.0 c.c. & 13.0 c.c. & $1-280$ \\
6 & 1.0 c.c. & 14.0 c.c. & $1-300$ \\
7 & 1.0 c.c. & 15.0 c.c. & $1-320$ \\
8 & 1.0 c.c. & 16.0 c.c. & $1-340$ \\
9 & 1.0 c.c. & 17.0 c.c. & $1-360$ \\
10 & 1.0 c.c. & 18.0 c.c. & $1-380$ \\
11 & 1.0 c.c. & 19.0 c.c. & $1-400$ \\
\hline
\end{tabular}

1 c.c. of each dilution is then mixed in a Rosenau syringe with 2 c.c. of diluted toxin, the mixture allowed to stand one hour at room temperature, injected subcutaneously into a guinea pig in the manner described for determining the MLD, the syringe washed with salt solution and the pigs numbered and carefully observed. Should pigs receiving dilutions 1 to 3 survive for five days, and the pigs receiving the higher dilutions die in two to five days the serum in question would contain 260 units per c.c. Guinea pigs which die should be autopsied and the characteristic lesions found.

To provide a margin of safety in testing commercial sera it is customary to consider the smallest unit which serves to protect the pig as a unit, in this case $\frac{1}{240}$ of 1 c.c., which means that there are 240 units to the cubic centimeter.

Materials needed for III, Determination of unknown antitoxin :

Antitoxin.

Diphtheria toxin whose M. L. Dose and L+ Dose are exactly known. Precision syringes.

12 guinea pigs of approximately 250 grams weight.

\section{LESSON XXIII}

\section{TETANUS TOXIN}

\section{Tetanolysin and Antitetanolysin}

MANY bacteria, for instance tetanus bacillus, Staphylococcus, various vibrios, Bacillus megatherium and Bacillus proteus, develop, in culture media, substances which are capable of laking red cells. These substances are relatively thermolabile and 

deteriorate readily in solution. They are known as hæmotoxins and their injection in suitable doses into animals leads to the production of antitoxins whose specific protective action can be demonstrated in vitro.

These hæmotoxins also have a hæmolytic action in the body, although they play a smaller role than the other toxic components (neurotoxin, for instance, in the case of tetanus). Their in vivo hæmolytic effect is probably greatly hindered by the protective power which normal serum possesses when in sufficient concentration.

\section{Determination of Minimal Laking Dose of Tetanus Toxin}

Tetanus toxin (either a recently prepared filtrate or a toxin precipitated with ammonium sulphate and preserved in the dry state and made up to 1 per cent solution in 0.9 per cent saline) ${ }^{2}$ is tested as follows :

\begin{tabular}{c|c|c|c}
\hline Tube & Toxin Solution & $5 \%$ Rabit Cello & S \\
\cline { 2 - 3 } 1 & 0.5 c.c. & 0.5 c.c. & 1.0 c.c. \\
2 & 0.2 c.c. & 0.5 c.c. & 1.3 c.c. \\
3 & 0.1 c.c. & 0.5 c.c. & 1.4 c.c. \\
4 & 0.05 c.c. & 0.5 c.c. & 1.45 c.c. \\
5 & 0.0 & 0.5 c.c. & 1.5 c.c. \\
\hline \hline
\end{tabular}

Incubate one hour at $37^{\circ} \mathrm{C}$, , and observe hæmolysis.

II. Titration of Antitetanolysin in Immune Horse Serum (Tetanus Antitoxin)

\begin{tabular}{|c|c|c|c|c|}
\hline TUBE & Toxin & \multicolumn{2}{|c|}{ IMmUNe SerdM } & $\begin{array}{l}\text { SALINE TO MAKE VoLUMES } \\
\text { UP TO } 1.5 \text { C.c. }\end{array}$ \\
\hline \multirow{6}{*}{$\begin{array}{l}1 \\
2 \\
3 \\
4 \\
5\end{array}$} & \multirow{10}{*}{$\begin{array}{c}\text { One minimal laking dose } \\
\text { "6 } \\
\text { "6 }\end{array}$} & $1-1000$ & 1.0 c.c. & “ \\
\hline & & $1-1000$ & 0.5 c.c. & “ \\
\hline & & $1-10,000$ & 1.0 c.c. & “ \\
\hline & & $1-10,000$ & 0.5 c.c. & " \\
\hline & & $1-10,000$ & 0.2 c.c. & “ \\
\hline & & \multicolumn{2}{|c|}{ Normal Horse Serum } & \\
\hline 6 & & $1-100$ & 1.0 c.c. & “ \\
\hline 7 & & $1-1000$ & 1.0 c.c. & “ \\
\hline 8 & & No serum & & “ \\
\hline 9 & & $1-100$ & 1.0 c.c. & “6 \\
\hline
\end{tabular}

${ }^{1}$ A preliminary trial by the instructor is desirable before the toxin is given out to the class, as the quantities of toxin given in the table may have to be modified. 

After one half hour at $37^{\circ}$ C. add 0.5 c.c. of 5 per cent rabbit cells to all tubes, incubate one hour, and observe hæmolysis.

Tube 8 is inserted, of course, to make certain that the toxin does not lose its hæmolytic power during the half hour of preliminary incubation, and Tube 9 to show that horse serum is not of itself hæmolytic.

\section{TEtanospasmin}

Students should work in groups of three or four in performing the following experiments. Fresh tetanus toxin is obtained from a department of health or one of the commercial laboratories with the lethal dose for guinea pigs of 350 grams worked out. Tetanus antitoxin can be procured from the same source or in the market.

$A$. Inject a guinea pig of approximately 350 grams into the thigh of one hind leg with five lethal doses of the tetanus toxin.

$B$. A similar guinea pig at the same time is injected with twice the dose, i.e. ten lethal doses of tetanus toxin, which has been mixed with one antitoxin unit, ${ }^{1}$ the mixture having been allowed to stand at room temperature for twenty minutes.

$C$. Grind up five lethal doses of the tetanus toxin with half of one cortex of fresh guinea pig brain, adding salt solution to the amount of 3 or 4 c.c. during the process. This mixture is allowed to stand at room temperature for two or three hours. It is then centrifugalized and the supernatant fluid injected into a third pig.

The pigs are kept under close observation for 6 days.

Materials required for each student for the tetanolysin experiments: Tetanus toxin

Tetanus antitoxin

Normal horse serum

about 4 c.c.

about 0.1 c.c.

5 per cent rabbit-cell suspension 8.0 c.c.

Materials for each group of 3 or 4 students for the tetanospasmin experiment :

3 guinea pigs of about 350 gms. each.

20 lethal doses of tetanus toxin of known toxicity.

Tetanus antitoxin, one unit.

$\frac{1}{2}$ fresh guinea pig brain.

1 The antitoxin unit is established by the United States Hygienie Laboratory (Bulletin 43) on principles similar to those used for diphtheria antitoxin and represents ton times the amount of antitoxin necessary to eompletely neutralize 100 minimal lethal doses of a standard toxin injected into a guinea pig of 350 grams. 



\section{LESSON XXIV}

\section{TOXINS OF HIGHER PLANTS AND ANIMALS}

MANY of the higher plants and animals produce toxins resembling in every way the toxins of bacterial origin. The property which is essential for the identification of such substances as toxins is the possibility of producing antitoxins for them. The other properties, such as the extraordinary potency and thermolability, are less essential. Most of them have more than one toxic component, like many of the bacterial toxins (for instance, tetanus toxin). Thus beside the effect on the nervous system and blood vessels snake poisons are hæmolytic, and ricin, a powerful toxin derived from the castor bean, is hæmagglutinative.

Human and guinea pig cells are susceptible to laking by cobra venom in the absence of serum or lecithin. Sheep and ox cells are highly resistant. The addition of lecithin or of suitable serum, however, makes the insusceptible cells again susceptible to laking by the venom.

Kyes at first supposed that the lecithin "activated" the hæmolysin of the cobra venom by an action analogous to that of complement in the case of the specific hæmolysins. Later researches, especially those of von Dungern and Coca, showed that the venom contained a lipoid-splitting enzyme or lipase which acted upon the lecithin of the cell membrane or the lecithin contents of the serum and liberated split products which possessed hæmolytic action.

Set up the following tests :

Hemolytic Effect of Cobra Venom

\begin{tabular}{|c|c|c|c|c|}
\hline TUBE & Red Blood Cells & \begin{tabular}{|c|} 
GUINEa Pig SERUM OR \\
LECITHIN EMOLIION \\
$1-2000$ \\
\end{tabular} & $\begin{array}{c}\text { COBRA VENOM } \\
1-1000\end{array}$ & SALt Solution \\
\hline 1 & Guinea pig cells $5 \% 0.5$ & - & 0.1 c.c. & 0.9 c.c. \\
\hline 2 & Shoop cells & - & 0.1 c.c. & 0.9 c.c. \\
\hline 3 & Sheop cells & G. P. 0.1 c.c. & 0.1 c.c. & 0.8 c.c. \\
\hline 4 & Sheop colls & 0.4 c.c. & 0.1 c.c. & 0.5 c.c. \\
\hline 5 & Sheep colls & G. P. 0.1 c.c. & - & 0.9 c.c. \\
\hline 6 & Sheop cells & 0.4 c.c. & 一 & 0.6 c.c. \\
\hline
\end{tabular}

Incubate one hour at $37^{\circ} \mathrm{C}$., making observations every 15 minutes, and note whether the occurrence of hæmolysis confirms the statements made above. 



\section{Hamagglutinative Effect of Ricin}

Ricin agglutinates the cells of all species to a greater or lesser degree. The presence of serum in any considerable quantity interferes with the reaction. Specific antitoxic sera (which are difficult to prepare) neutralize in high dilutions not only the poisonous but also the agglutinative component of ricin.

\begin{tabular}{c|c|c|c}
\hline \hline Tube & Guinea Pig Cells $5 \%$ & Ricin 1-1000 & Sheep Serum \\
\cline { 2 - 4 } 1 & 0.5 c.c. & 0.1 c.c. & - \\
2 & 0.5 c.c. & 0.5 c.c. & - \\
3 & 0.5 c.c. & 1.0 c.c. & - c.c. \\
4 & 0.5 c.c. & 0.1 c.c. & 1.0 c.c. \\
5 & 0.5 c.c. & 0.5 c.c. & 1.0 c.c. \\
6 & 0.5 c.c. & 1.0 c.c. & \\
\hline \hline
\end{tabular}

Make all volumes equal by adding saline. Incubate one hour. Observe hæmagglutination.

Each student requires:

5.0 c.c. guinea pig cells $5 \%$.

0.5 c.c. guinea pig serum.

7.0 c.c. sheep cells.

8.0 c.c. sheep serum.

1.0 c.c. lecithin diluted $1-2000$.

1.0 c.c. cobra venom diluted $1-1000$.

4.0 c.c. ricin diluted $1-1000$.

Salt solution.

\section{LESSON XXV}

\section{DETERMINATION OF ANTITRYPTIC ACTIVITY OF BLOOD SERUM}

Normal blood contains a trypsin-like ferment. This enzyme digests protein in neutral or weakly alkaline solution, with the formation of amino-acids. Under ordinary conditions its action is inhibited by the presence of substances in serum which have been shown by Jobling and Peterson to be compounds of unsaturated fatty acids.

This antitryptic activity is greatly increased in cachectic 

individuals and tests for increase in antitrypsin have been proposed as an aid to diagnosis of carcinoma. The condition, however, is not limited to patients with malignant diseases, but is present also in pernicious anæmia, in Graves' disease, in advanced tuberculosis, and in many other infections.

A specific antitrypsin which may be quite different in its nature from the substance present in normal serum is developed in response to injections of trypsin into animals. The precise determination of the antitryptic activity of the serum in experimental work is made by adding serum to mixtures of trypsin and some protein substrate and after incubation comparing the amount of incoagulable nitrogen in the flasks containing serum with the amount in control flasks containing trypsin alone.

Simpler methods have been devised for clinical use. One widely used consists in placing drops of mixtures of trypsin and serum in varied proportion on the surface of Loeffler's blood serum plates and determining the action of the trypsin by the formation of a pit on the surface of the plate underneath the drop of fluid.

A more satisfactory method is that of Fuld and Gross as follows: Mixtures of serum with varying concentrations of trypsin are allowed to act on an alkaline solution of casein and after incubation the undigested casein is precipitated by the addition of acetic acid.

Reagents :

1. Trypsin solution. Dissolve 0.5 gram of trypsin in 50 c.c. of salt solution containing 0.5 c.c. of normal soda. Make up to 500 c.c. with salt solution. Samples of commercial trypsin vary greatly in their activity and this stock solution should be diluted if necessary until the amount required to digest 2 c.c. of casein solution is approximately 0.5 c.c.

2. Casein solution. Dissolve 1 gram of casein in 100 c.c. of N/10 $\mathrm{NaOH}$ by warming and neutralize the solution with $\mathrm{N} / 10 \mathrm{HCl}$, using litmus as an indicator. The volume is brought up to 500 c.c. with salt solution and the solution filtered. It should be sterilized in the Arnold sterilizer if it is not to be used immediately.

3. Acetic acid solution composed of glacial acetic acid 5 c.c., alcohol 45 c.c., water 50 c.c. 



\section{A. Titration of Trypsin Solution}

In each of a series of test tubes place decreasing amounts of trypsin solution, 1 c.c., $0.7,0.5,0.4,0.3$ and 0.2 c.c. Add sufficient salt solution to bring up the volumes to 2.5 c.c. and set up a control containing 2.5 c.c. of saline alone. To each tube add 2 c.c. of casein solution, shake, and place in water bath for half an hour at $37^{\circ} \mathrm{C}$. Remove the tubes from the water bath and add 3 to 4 drops of the acetic acid solution to each. The tube with the smallest amount of trypsin which shows no precipitate of undigested casein contains the amount of trypsin needed for the subsequent test.

\section{Preliminary Titration of Trypsin}

\begin{tabular}{|c|c|c|c|c|}
\hline TUBE & Trypsin Solution & SALINE & Casenn Solution & REsult \\
\hline $\begin{array}{l}1 \\
2 \\
3 \\
4 \\
5 \\
6 \\
7\end{array}$ & $\begin{array}{l}1.0 \text { c.c. } \\
0.7 \text { c.c. } \\
0.5 \text { c.c. } \\
0.4 \text { c.c. } \\
0.3 \text { c.c. } \\
0.2 \text { c.c. } \\
0.0 \text { c.c. }\end{array}$ & $\begin{array}{l}1.5 \text { c.c. } \\
1.8 \text { c.c. } \\
2.0 \text { c.c. } \\
2.1 \text { c.c. } \\
2.2 \text { c.c. } \\
2.3 \text { c.c. } \\
2.5 \text { c.c. }\end{array}$ & $\begin{array}{l}2.0 \text { c.c. } \\
2.0 \text { c.c. } \\
2.0 \text { c.c. } \\
2.0 \text { c.c. } \\
2.0 \text { c.c. } \\
2.0 \text { c.c. } \\
2.0 \text { c.c. }\end{array}$ & \\
\hline
\end{tabular}

\section{B. Determination of Antitryptic Activity of Serum}

For control a mixture of several normal sera is used and a 2 per cent solution in normal saline is prepared. A 2 per cent solution of the serum to be tested, preferably from a case of advanced carcinoma, is used for the test.

In order to demonstrate the lipoidal nature of normal antitrypsin it can be removed from serum by chloroform extraction. 4 c.c. of diluted normal serum should be placed in a test tube, 0.5 c.c. of chloroform added, the mixture thoroughly shaken and incubated for one hour, at the end of which time the mixture is centrifugalized and the clear supernatant fluid pipetted off. The normal serum, the carcinoma serum, and the normal serum after chloroform extraction should be tested in parallel as follows:

In each of six tubes place 0.5 c.c. of the 2 per cent solution of serum. To the first tube add the dose of trypsin which will completely digest the casein as determined by previous titration (this is "the unit" of trypsin), and in the successive tubes increasing amounts of the trypsin so that Tube 6 contains four times as much trypsin as Tube 1. For example, if 

in the preliminary test the tube containing 0.5 c.c. of trypsin solution was completely dissolved this series of tubes should contain $0.5,0.75,1.0$, $1.25,1.5$ and 2.0 c.c. respectively. Sufficient salt solution is added to bring the volumes up to 2.0 c.c., and 2.0 c.c. of casein solution added to each tube. The tubes are incubated for one half hour and at the end of this time the undigested casein is precipitated by the addition of a few drops of the acetic acid solution.

In the presence of carcinoma serum from $1 \frac{1}{2}$ times to twice the amount of trypsin will be found necessary to completely digest the casein that is necessary in the presence of normal serum. On the other hand, in the serum which has been extracted with chloroform the antitryptic activity will be found to have been almost completely removed.

Testing of Serum

\begin{tabular}{|c|c|c|c|c|c|}
\hline TUBE & $\begin{array}{l}\text { TRYPBIN } \\
\text { SoLUTION }\end{array}$ & $\begin{array}{c}\text { Patient's } \\
\text { SERUM - 2\% }\end{array}$ & $\begin{array}{c}\text { SALINE TO BRING } \\
\text { VOLUMES UP TO } 2 \text { c.c. }\end{array}$ & $\begin{array}{l}\text { Casein } \\
\text { Solution }\end{array}$ & Result \\
\hline $\begin{array}{l}1 \\
2 \\
3 \\
4 \\
5 \\
6 \\
7\end{array}$ & $\begin{array}{l}1 \text { unit } \\
1 \frac{1}{2} \text { units } \\
2 \text { units } \\
2 \frac{1}{2} \text { units } \\
3 \text { units } \\
4 \text { units } \\
\text { None }\end{array}$ & $\begin{array}{l}0.5 \text { c.c. } \\
0.5 \text { c.c. } \\
0.5 \text { c.c. } \\
0.5 \text { c.c. } \\
0.5 \text { c.c. } \\
0.5 \text { c.c. } \\
0.5 \text { c.c. }\end{array}$ & $\begin{array}{l}16 \\
66 \\
66 \\
66 \\
66 \\
6\end{array}$ & $\begin{array}{l}2 \text { c.c. } \\
2 \text { c.c. } \\
2 \text { c.c. } \\
2 \text { c.c. } \\
2 \text { c.c. } \\
2 \text { e.c. } \\
2 \text { c.c. }\end{array}$ & \\
\hline
\end{tabular}

\section{LESSON XXVI}

\section{NATURE OF NORMAL OPSONIN}

\section{INTRODUCTORY REMARKS}

IN the early days of immunological investigation it was supposed that phagocytosis depended upon properties inherent in the phagocyting cell. More recent investigations, starting with those of Metchnikoff, continued by Denys and Leclef and others, and brought to focus by Wright and his associates, have shown that in phagocytosis, at least when carried on by the polynuclear cells of the circulating blood, it is a function of the coöperation of serum and phagocyte. It has been found that the serum so acts upon the bacteria that they are rendered more easily 

taken up by the leucocytes, and that the serum constituent which carries out such preparatory action is comparable to other antibodies. The property of the serum which carries out this preparation of the bacteria for phagocytosis has been spoken of by Wright as the opsonic power, since he supposed it to depend upon a specific antibody, which he called opsonin. In immune sera this phagocytosis-aiding antibody is more heat-resistant than it is in normal sera, and such a heat-resistant immune body is spoken of by the Wright school as the immune opsonin and by Neufeld and his associates as bacteriotropin.

Serum. - Obtain normal guinea pig serum by bleeding two pigs from the carotid into centrifuge tubes and separating serum.

Leucocytes. - Wash out peritoneum of two guinea pigs injected intraperitoneally with 6 c.c. of aleuronat suspension ${ }^{1}$ about 8 to 12 hours before. Take 2 c.c. of suspension, centrifugalize, wash the sediment once in saline and suspend in saline until emulsion corresponds in thickness to standard tube prepared by instructor.

Bacteria. - Make suspension of staphylococcus aureus from agar culture in salt solution until thickness corresponds to standard tube. Draw in and out of capillary pipette until the bacteria are evenly emulsified. Allow clumps to settle and pipette off upper layers.

\section{Experiment 1}

\section{Opsonic Action of Serum}

Set up three tubes as follows:

\begin{tabular}{|c|c|c|c|c|}
\hline TUBE & Gunnea Pig $\mathrm{S}$ & SERUM & SUSPENSION OP BACTERIA & StRPENSION OF LEUCOCYTES \\
\hline $\begin{array}{l}1 \\
2 \\
3\end{array}$ & $\begin{array}{l}\text { Fresh } \\
\text { (Inactivated) } \\
\text { Salt solution }\end{array}$ & $\begin{array}{l}0.25 \text { c.c. } \\
0.25 \text { c.c. } \\
0.25 \text { c.c. }\end{array}$ & $\begin{array}{l}0.1 \text { c.c. } \\
0.1 \text { c.c. } \\
0.1 \text { c.c. }\end{array}$ & $\begin{array}{l}0.2 \text { c.c. } \\
0.2 \text { c.c. } \\
0.2 \text { c.c. }\end{array}$ \\
\hline
\end{tabular}

All tubes are incubated one half hour at $37^{\circ} \mathrm{C}$. Two smears are then made of the sediment on slides and stained by Gram's method, or with Jenner's stain. To obtain material for smears pour out the supernatant fluid and scrape the leucocytes from the bottom of the tube with a platinum loop. The bacteria in a hundred consecutive leucocytes on each slide are then counted.

1 To make aleuronat suspension take

$\begin{array}{lr}\text { Aleuronat } & 5 \\ \text { Starch } & 3 \\ \text { Water or broth } & 100\end{array}$

Mix cold. Bring to a boil. Tube and sterilize.

For washing out the guinea pig's abdomen use sod, citrate solution in saline. 



\section{Experiment 2}

The Opsonin Unites With the Bacteria, Not With the LEUCOCYTES

In two small centrifuge tubes mixtures are made with the same materials employed in Experiment 1, as follows :
(1) Bacterial suspension
Fresh guinea pig serum
0.1 c.c.
Salt solution
0.2 c.c.
(2) Leucocyte suspension
0.7 c.c.
Fresh guinea pig serum
0.2 c.c.
Salt solution
0.2 c.c.
0.6 c.c.

These tubes are allowed to stand at $37^{\circ} \mathrm{C}$. in water bath or incubator for 30 minutes. Then centrifugalize vigorously and wash sediment once in salt solution.

To the bacterial sediment of (1) add :
Leucocyte suspension
0.2 c.c.
Salt solution
0.3 c.c.

To the leucocyte sediment of (2) add :
Bacterial suspension
Salt solution
0.1 c.c.
0.4 c.c.

Allow the tubes to stand for 30 minutes at $37^{\circ} \mathrm{C}$. Then make smears and examine as in Experiment 1.

Materials:

Serum, leucocytes, bacterial emulsion as described.

Microscope slides.

2 Centrifuge tubes.

Capillary pipettes with rubber nipples. Jenner's stain.

$5 \frac{1}{2}$-inch test tubes.

\section{LESSON XXVII}

\section{DETERMINATION OF OPSONIC INDEX (WRIGHT)}

Prepare the following reagents:

1. Bacillary suspension. Make suspension of Staphylococcus aureus culture in salt solution. Allow to stand in test tube for clumps to settle out. Transfer upper portion to separate test tube.

2. Leucocyte suspension. Obtain 15 or more drops of blood from finger tip in centrifuge tube containing about 10 c.c. of citrate solution. 

(Sodium citrate 1 gram, sodium chloride 0.5 gram, water 100 c.c.) Centrifugalize and wash once in salt solution. With capillary pipette remove the upper layer of the sediment which will contain most of the leucocytes.

3. Serum. Collect about 10 drops of blood in Wright capsule. ${ }^{1}$ Seal the dry end in the flame and centrifugalize to obtain serum.

Use portion of serum to make control pool, mixing serum from 5 to 10 different individuals.

\section{Test}

Use capillary pipette ${ }^{1}$ with mark about $2 \mathrm{~cm}$. from the tip. Take up first serum to the mark, then air, then leucocytes to the mark, then bacteria. Mix the reagents in a watch glass and again draw into the pipette and seal the tip. Incubate one half hour. Blow out contents of capillary, mix thoroughly and make smears. Stain with Jenner's stain 4 minutes, wash and blot.

Each student makes test with his own serum and with a control pool which does not include his own.

The opsonic index is the ratio between the phagocytic average of the specimen with the patient's serum and of that with the normal pool, expressed as a decimal, i.e.

$$
\begin{aligned}
\text { "Normal" specimen - phagocyte average } & 2.5 \\
\text { Patient's specimen - phagocyte average } & 3.75 \\
\text { Opsonic index } & 1.5
\end{aligned}
$$

If the figures for normal and patient were reversed, the index would be 0.66 .

Materials:

Staphylococcus suspension.

Citrate solution.

Wright capsules and pipettes.

Jenner's stain.

\section{LESSON XXVIII}

\section{DIFFERENCE IN HEAT STABILITY BETWEEN NORMAL AND IMMUNE OPSONINS OR BACTERIOTROPINS}

Prepare materials - bacterial (staphylococcus) emulsion leucocytes and serum as for opsonin test by Wright's method. 



\section{Experiment 1}

\section{Heat Susceptibility of Normal Opsonin}

Divide the normal serum obtained from own finger into two parts. Heat one of these in a water bath at $56^{\circ} \mathrm{C}$. for 30 minutes.

Now carry out opsonin tests in parallel (1) with unheated serum, (2) with the heated serum - using same bacterial emulsion and leucocytes in both cases.

Compare results by counting slides.

\section{Experiment 2}

\section{Heat Susceptibility of Immune Opsonin}

Staphylococcus immune rabbit serum will be given out.

Divide into two parts. Heat one part to $56^{\circ} \mathrm{C}$. for 20 minutes in a water bath.

Carry out parallel tests as above and compare the results.

Materials :

Staphylococcus emulsion.

Glass tubing for Wright capsules and pipettes.

Staphylococcus immune serum.

\section{LESSON XXIX}

\section{TITRATION OF NORMAL OPSONIN BY DILUTION METHOD}

Titrate opsonic power of normal guinea pig serum for Staphylococcus aureus by dilution method as follows :

1. Make dilutions of serum 1-5, 1-10, 1-20, 1-100.

2. Set up series of opsonic tests in Wright capillary pipette, using staphylococcus suspension, suspension of guinea pig leucocytes and diluted serum equal parts. Make additional test with undiluted serum, and also control with leucocytes, bacteria and salt solution.

3. Incubate 30 minutes, make smears and stain with Jenner's stain. Determine by counts in which dilution there is a definite increase of phagocytosis as compared with the salt solution control.

Materials : same as for two preceding lessons. 



\section{LESSON XXX}

\section{TITRATION OF IMMUNE OPSONIN BY DILUTION METHOD}

\section{INTRODUCTORY REMARKS}

THERE are several methods of titrating the opsonic power of a serum. The most accurate method probably is that in which a number of progressively increasing dilutions of the serum are made and the opsonic power of each dilution is tested. In this way the degree of dilution at which the opsonic power of the serum disappears, that is, at which there is not more phagocytosis in the specimen with this serum than there is in a control with salt solution, is determined. In this way two sera can be compared as to their opsonic strength. It is the method first used by Klein in the case of typhoid opsonins, and the one utilized by Jobling in the standardization of anti-meningococcus serum.

Reagents :

1. Suspension of Staphylococcus aureus from 24-hour agar slant.

2. Suspension of leucocytes obtained from peritoneum of guinea pig injected with aleuronat.

(The method of preparing these two suspensions has been given in a previous lesson.)

3. Serum of rabbit immunized against Staphylococcus aureus.

Before beginning the experiment 0.2 c.c. of this serum should be placed in test tube and heated one half hour at $56^{\circ}$ for Series III below.

4. Serum of normal rabbit.

Prepare dilutions of each of the sera, 1-5, 1-10, 1-20 and 1-100.

Set up a series of six tubes. In the first put 0.25 c.c. of undiluted immune serum, in the next four 0.25 c.c. of $1-5,1-10,1-20$ and 1-100 dilutions respectively, and in the last tube 0.25 c.c. of salt solution for control.

\section{II}

Set up a similar series with normal serum, omitting the fifth and sixth tubes. 


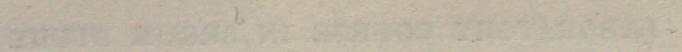

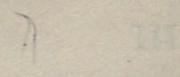

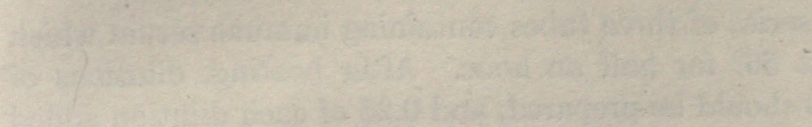

.

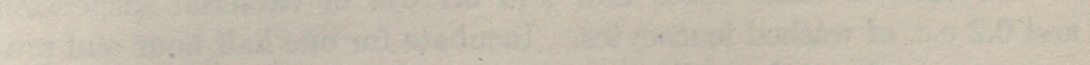

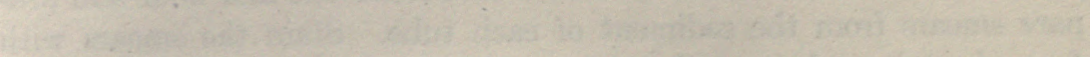

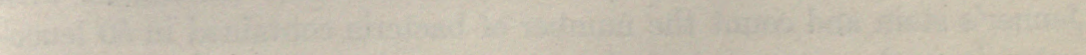

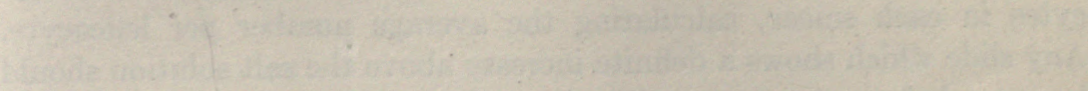

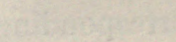

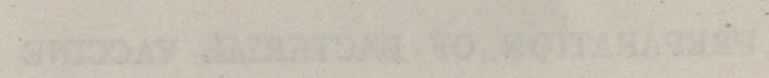

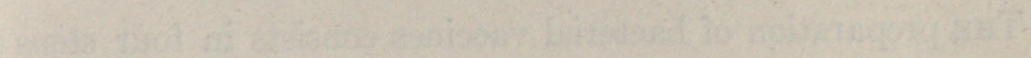

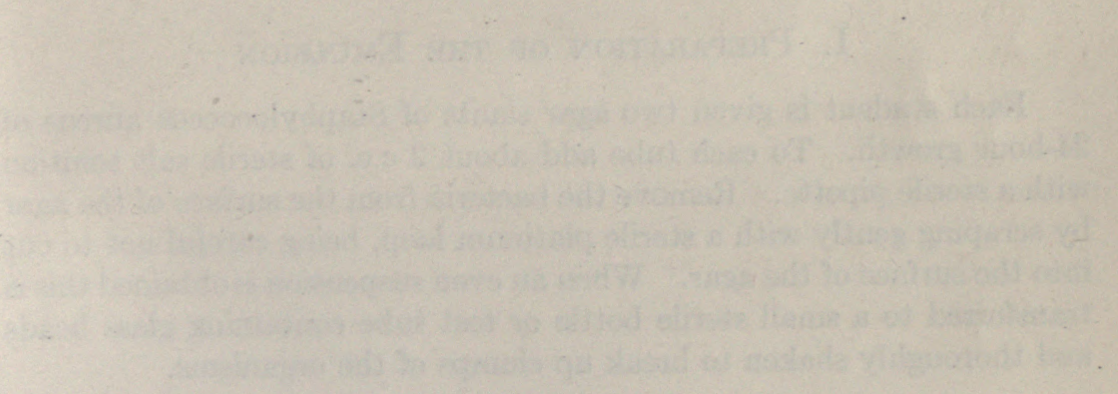

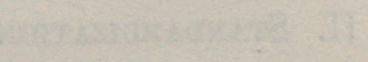

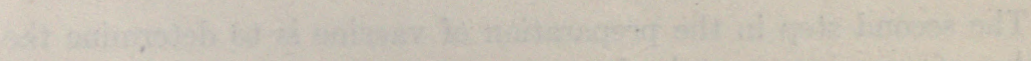

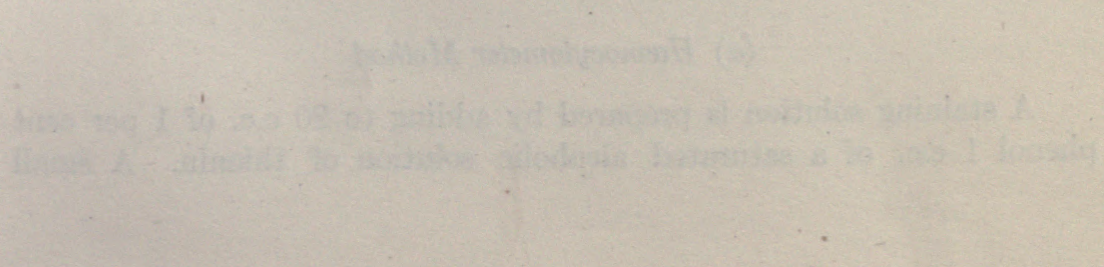


III

Set up a third series of three tubes containing immune serum which has been heated at $56^{\circ}$ for half an hour. After heating, dilutions of 1-5, 1-10 and 1-20 should be prepared, and 0.25 of each dilution added to one of the tubes.

To each of these tubes now add 0.1 c.c. of bacterial suspension and 0.2 c.c. of washed leucocytes. Incubate for one half hour and prepare smears from the sediment of each tube. Stain the smears with Jenner's stain and count the number of bacteria contained in 50 leucocytes in each smear, calculating the average number per leucocyte. Any slide which shows a definite increase above the salt solution should be regarded as showing positive opsonic power in the corresponding dilution of serum.

Materials: same as three preceding lessons.

$15 \frac{1}{2}$-inch tést tubes. $5 \frac{3}{4}$-inch test tubes.

\section{LESSON XXXI}

\section{PREPARATION OF BACTERIAL VACCINE}

THE preparation of bacterial vaccines consists in four steps:

\section{Preparation of the Emulsion}

Each student is given two agar slants of Staphylococcus aureus of 24-hour growth. To each tube add about 2 c.c. of sterile salt solution with a sterile pipette. Remove the bacteria from the surface of the agar by scraping gently with a sterile platinum loop, being careful not to cut into the surface of the agar. When an even suspension is obtained this is transferred to a small sterile bottle or test tube containing glass beads and thoroughly shaken to break up clumps of the organisms.

\section{Standardization}

The second step in the preparation of vaccine is to determine the number of organisms contained per c.c.

\section{(a) Homocytometer Method}

A staining solution is prepared by adding to 20 c.c. of 1 per cent phenol 1 c.c. of a saturated alcoholic solution of thionin. A small 

amount of the carefully shaken bacterial suspension is removed to a watch glass. A 1-100 dilution is prepared in a red cell pipette with the staining solution as diluent to the 101 mark. After carefully shaking and after blowing out the portion of the fluid in the capillary end of the pipette, a small drop is placed in a counting chamber and covered with a flat cover slip. After allowing 15 minutes for the bacteria to settle, a count is made, with a No. 5 or a No. 6 lens, of a number of squares until 200 or more bacteria have been counted. It is best to take this count from different portions of the ruled surface and from two separate drops of the mixture. The small squares have an area of $\frac{1}{400}$ of a square mm., the depth of the chamber is $0.1 \mathrm{~mm}$., the dilution is 1-100. The number of bacteria may be estimated by the following formula: $\frac{\text { No. of bacteria counted } \times 400 \times 10 \times 100 \times 1000}{\text { Number of squares counted }}=\begin{gathered}\text { Number of bac- } \\ \text { teria in } 1 \text { c.c. }\end{gathered}$

\section{(b) Wright's Method}

A Wright capillary pipette is prepared with a mark about one inch from the tip. A small puncture is made in the tip of the finger and a fresh drop of blood obtained. Three units of salt solution are then drawn up in the pipette, admitting a bubble of air between each two portions of salt solution. Blood from the finger tip is then drawn up to the mark, a bubble of air admitted, and bacterial suspension drawn up to the mark. The mixture is then blown out on a clean slide and drawn in and out of the pipette several times to insure even mixing of the blood and bacteria. A drop of this mixture is placed on a second slide and carefully spread across the slide in the manner of making blood smears. It is important that the film be thin and even so that the red cells are not piled in masses in any portion of the film. This film is stained with Jenner's stain, or by any other simple method, and a differential count of the number of bacteria and red cells in a number of fields in different parts of the slide is made. For this a ruled scale to be inserted in the eyepiece of the microscope is very helpful. A number of fields are counted, taken at random, until 200 red cells have been counted. The number of bacteria in the suspension may then be estimated from the number of bacteria counted, using the following formula (assuming that the blood of the worker contains 5,000,000 red cells per cubic mm.) :

$\frac{\text { Number of bacteria } \times 5,000,000 \times 1000}{\text { Number of red cells }(200)}=$ Number of bacteria per c.c. 



\section{(c) Other Methods}

A number of other methods have been devised for standardization of vaccines.

One method (Hopkins) is to centrifugalize at high speed in a special tube with graduated tip until the supernatant fluid is clear. The number of organisms for a number of species in such a closely packed sediment has been determined, and is as follows :

$\begin{array}{ll}\text { Staphylococcus aureus } & 0.01 \text { c.c. equals } 10 \text { billion } \\ \text { Streptococcus hæmolyticus } & 0.01 \text { c.c. equals } 8 \text { billion } \\ \text { Gonococcus } & 0.01 \text { c.c. equals } 8 \text { billion } \\ \text { Pneumococcus (capsulated) } & 0.01 \text { c.c. equals } 2.5 \text { billion } \\ \text { B. typhosus } & 0.01 \text { c.c. equals } 8 \text { billion } \\ \text { B. coli } & 0.01 \text { c.c. equals } 4 \text { billion }\end{array}$

Another method of standardization is by the turbidity of the emulsion. Standard tubes of carefully counted suspensions are prepared, and the vaccine to be standardized is then diluted until the turbidity is equal to that in the standard tube.

\section{Sterilization}

The most reliable means of sterilization is by means of heat. For staphylococci and streptococci $59^{\circ}$ to $60^{\circ} \mathrm{C}$. for half an hour is satisfactory; for typhoid bacilli $55^{\circ}$ to $56^{\circ}$ for an hour is usually used. In heating, the bacteria should be placed in a sealed tube and the entire tube immersed in the water bath. After exposure to heat test the sterility of the vaccine by transferring two or three loopfuls of the suspension to an agar slant.

\section{Dilution}

The stock suspension prepared is as a rule too concentrated to allow the accurate measurement of the dose desired, which may vary according to the organism from 20 to 500 millions or even more. After the vaccine has been sterilized by heat, sufficient 5 per cent phenol or an equivalent quantity of other aromatic disinfectant should be added to bring the content of phenol in the mixture up to 0.5 per cent.

Each student will prepare a suspension from the cultures given out, standardize this suspension by methods $(a)$ and $(b)$, heat at $59^{\circ}$ for half an hour, test for sterility, and prepare two dilutions, one containing 200 million and one containing 1000 million per c.c. 

Materials :

2 agar slants of staphylococcus aureus.

Sterile saline solution.

Sterile pipette.

Sterile tube or bottle with glass beads.

Hæmocytometer.

Thionin solution in 1 per cent phenol.

Glass slides.

Wright or Jenner stain.

Phenol.

\section{LESSON XXXII}

\section{ANAPHYLAXIS}

\section{INTRODUCTORY REMARKS}

BECAUSE of the large number of animals required in this work, the class had better do these experiments in relatively large groups.

\section{Active Sensitization}

Four guinea pigs of about 200 grams weight are etherized on operating boards for intravenous injection into external jugular veins.

Guinea pigs $(a)$ and $(b)$ receive 0.25 c.c. horse serum diluted with 1.75 c.c. salt solution.

Guinea pigs $(c)$ and $(d)$ receive 0.25 c.c. sheep serum diluted with 1.75 c.c. salt solution.

This should be done two weeks before the time for Lesson XXXII.

Two weeks after the sensitizing injection the pigs are again injected intravenously as follows, into opposite jugular vein :

(a) 0.5 c.c. of horse serum.

(b) 0.5 c.c. of sheep serum.

(c) 0.5 c.c. of sheep serum.

The results in $(a)$ and $(c)$ demonstrate anaphylactic shock.

The absence of symptoms in (b) demonstrate specificity.

Guinea pig $(d)$ is given 0.01 c.c. sheep serum subcutaneously four times, at one hour intervals. Observe carefully symptoms after each injection. Then give 0.5 c.c. sheep serum intravenously. Symptoms will be slighter than in $(a)$ and $(c)$. This demonstrates desensitization. 

Materials needed for each group of students :

4 guinea pigs.

1 c.c. horse serum.

1 c.c. sheep serum.

Syringe.

Scalpel, forceps, scissors, thread, for isolation and ligation of jugular vein.

Ether.

\section{LESSON XXXIII}

\section{ANAPHYLAXIS (Continued)}

\section{Passive Sensitization}

OвTAIN serum of rabbit which has been highly immunized to horse serum.

Make preliminary titration of precipitin of this serum for horse serum.

Inject 1.0 c.c. of this serum intravenously into each of three guinea pigs. After 24 hours inject into the opposite jugular vein as follows :

$$
\begin{array}{ll}
\text { Guinea pig }(a) & 0.1 \text { c.c. horse serum } \\
\text { Guinea pig }(b) & 0.3 \text { c.c. horse serum } \\
\text { Guinea pig }(c) & 1.0 \text { c.c. horse serum }
\end{array}
$$

Observe symptoms.

In case of anaphylactic death, immediately open chest and observe condition of lungs and also whether heart is still beating. While such an animal is dying it is important to watch carefully the gradual altera- tion of respirations, the great irregularity and slowing of breathing and the intense inspiratory efforts just before death. 

. 





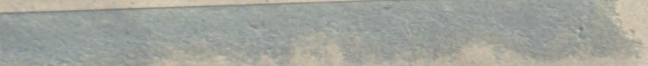
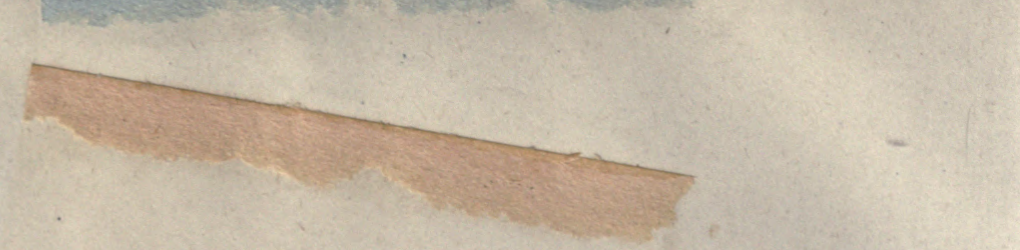


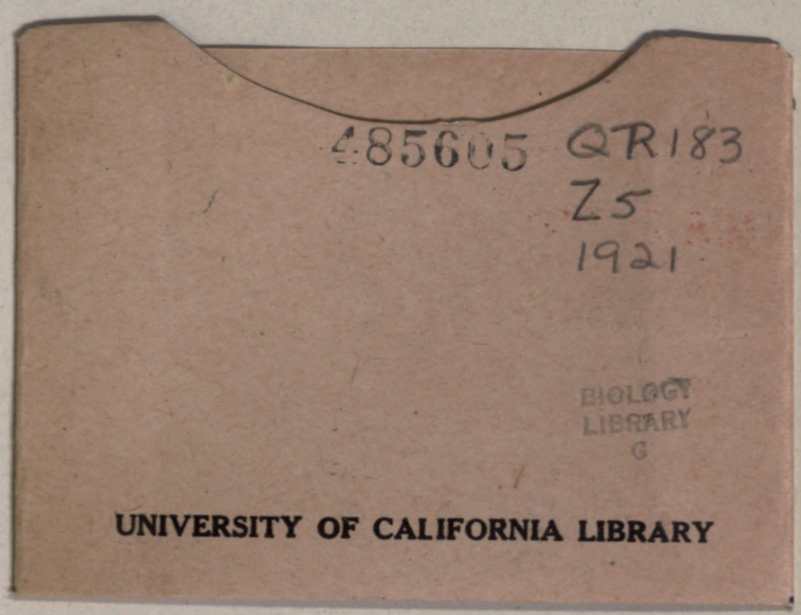


